BALOG DÓRA

TÖKEALLOKÁCIÓ A BIZTOSÍTÁSI SZEKTORBAN, ELMÉLETI ÉS GYAKORLATI MEGKÖZELÍTÉSBEN 
Befektetések és Vállalati Pénzügy Tanszék

Témavezető: Csóka Péter, PhD

Copyright ${ }^{\circledR}$ Balog Dóra 
BUDAPESTI CORVINUS EGYETEM

ÁLTALÁNOS ÉS KVANTITATÍV KÖZGAZDASÁGTAN

DOKTORI ISKOLA

\section{TŐKEALLOKÁCIÓ A BIZTOSÍTÁSI SZEKTORBAN, ELMÉLETI ÉS GYAKORLATI MEGKÖZELÍTÉSBEN}

DOKTORI ÉRTEKEZÉS

BALOG DÓRA BARBARA

Budapest, 2018 


\section{TARTALOMJEGYZÉK}

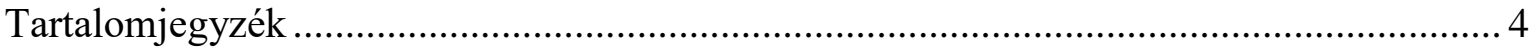

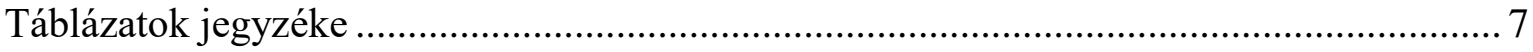

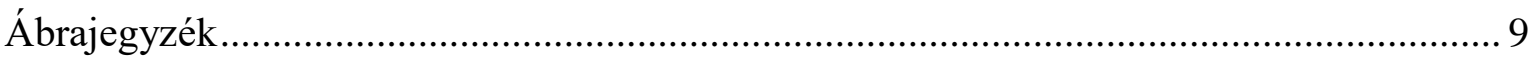

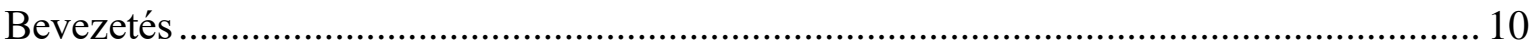

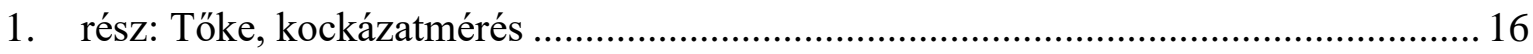

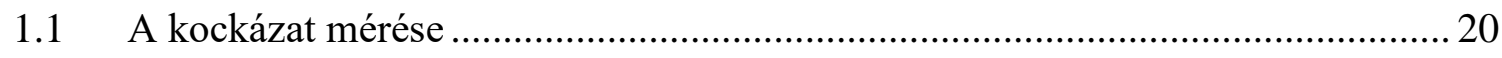

1.1.1 Az alkalmazott jelölések......................................................................... 21

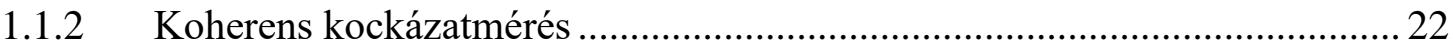

1.1.3 A leggyakrabban alkalmazott kockázatmértékek ........................................... 24

1.2 Tőkekövetelmény és tőkefogalmak a biztosítási szektorban .................................. 33

1.2.1 Szabályozói tőkekövetelmény - Szolvencia II................................................ 34

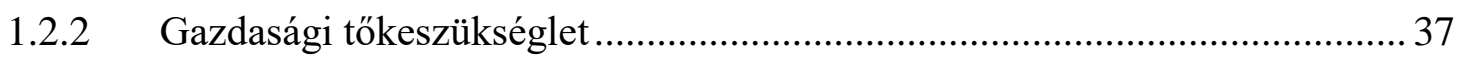

1.3 Költségjátékok - kooperatív játékelméleti kitérő ................................................. 38

2. rész: A tőkeallokáció elméleti modellje: az alkalmazható módszerek összehasonlítása 42

2.1 A tőkeallokációs probléma, jelölések ………………………………………….... 45

2.2 A hét módszer analitikus elemzésének eredményei.............................................54

2.2.1 Egyéni kockázattal arányos módszer............................................................ 56 


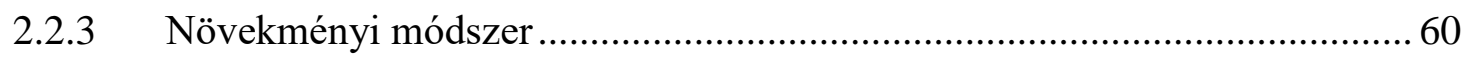

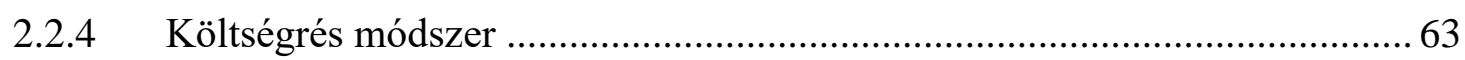

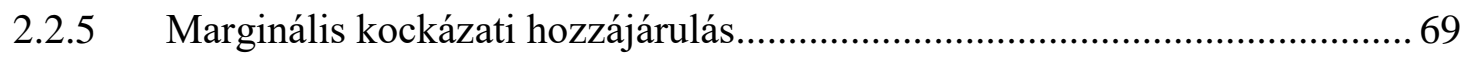

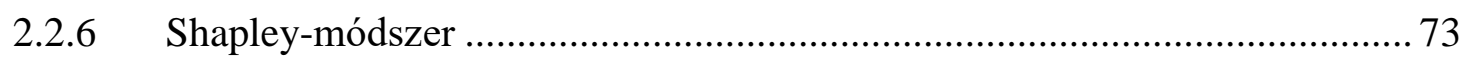

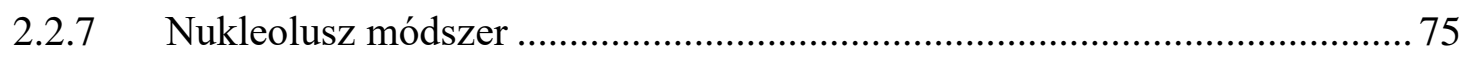

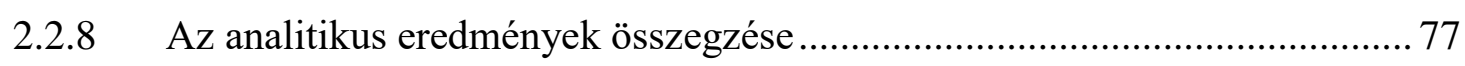

2.3 Szimulációs eredmények a magkompatibilitás ellenőrzésére ............................ 81

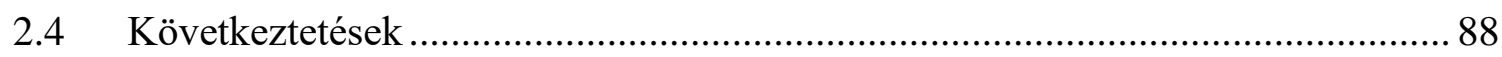

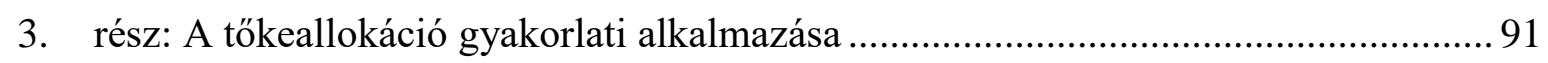

3.1 Miért - a tőkeallokáció különböző alkalmazásai............................................. 92

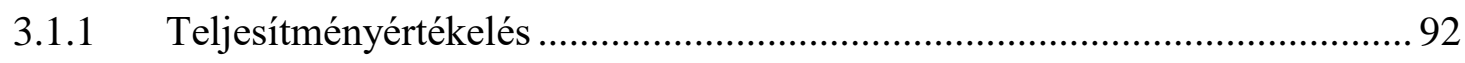

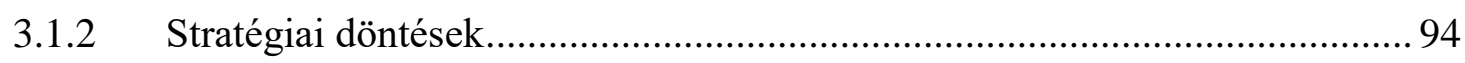

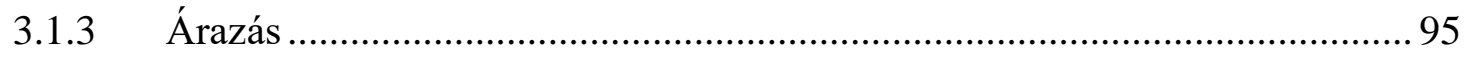

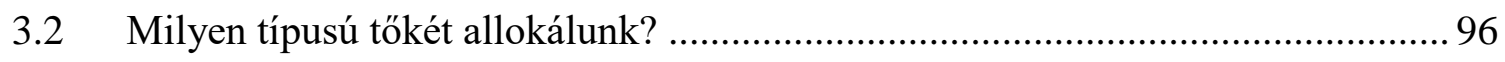

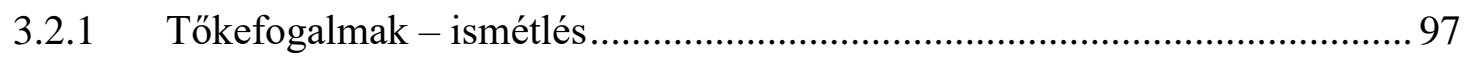

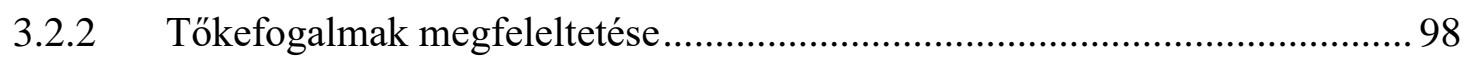

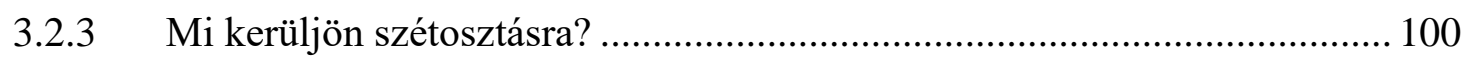

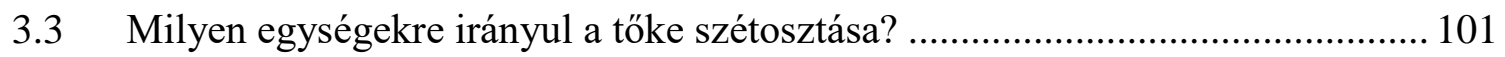

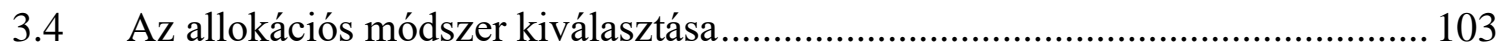

3.4.1 Az alkalmazható módszerek csoportosítása .......................................... 105

3.4.2 Módszerválasztás az alkalmazás függvényében..................................... 107 
3.5 Következtetések

4. rész: Esettanulmány - Teljesítményértékelés az ABC Biztosító Zrt-nél

4.1 A modell felépítése

4.1.1 Gépjármü felelősségbiztosítás ................................................................ 114

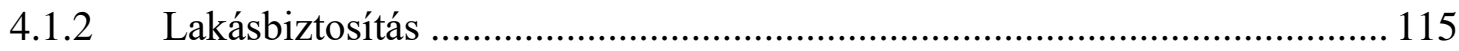

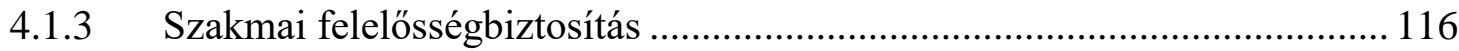

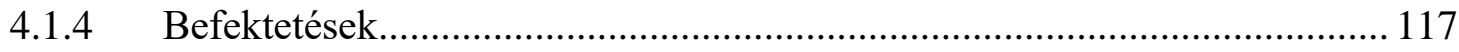

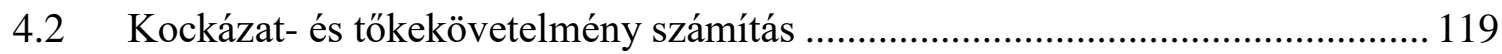

4.2.1 Tőkeallokáció és teljesítményértékelés ................................................. 120

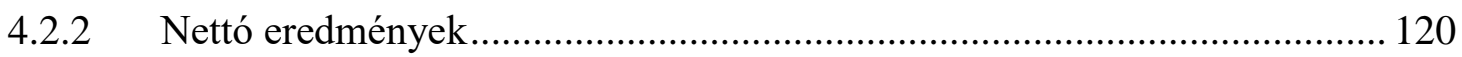

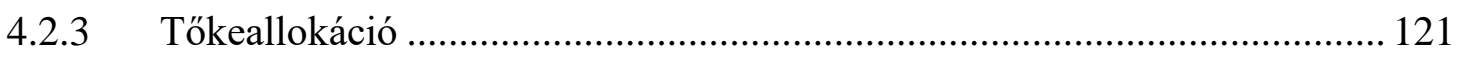

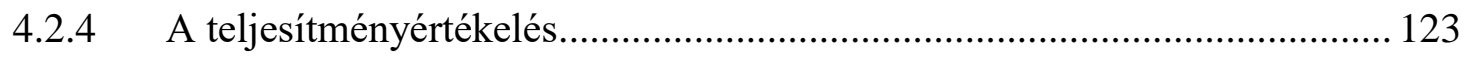

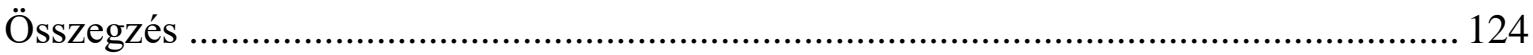

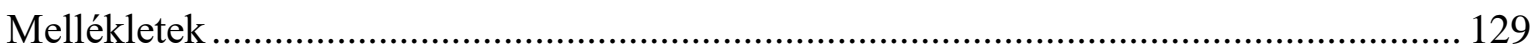

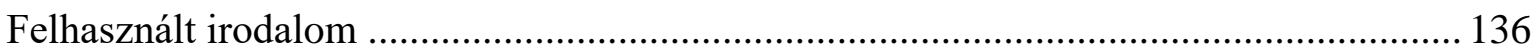

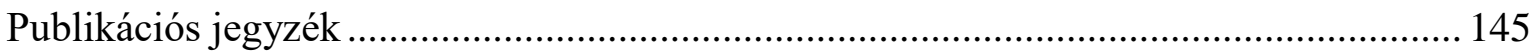




\section{TÁBLÁZATOK JEGYZÉKE}

1. TÁBLÁZAT: A SZÓRÁS NEM KOHERENS 26

2. TÁBLÁZAT: A VAR NEM KOHERENS $\quad 29$

3. TÁBLÁZAT: AZ EXPECTED SHORTFALL ÉS A FELTÉTELES VAR ELTÉRÉSE - DISZKRÉT ESET 32

4. TÁBLÁZAT: AZ XNP TŐKEALLOKÁCIÓS SZITUÁCIÓ $\quad 47$

5. TÁBLÁZAT: A 2.1.1. PÉLDABELI KOCKÁZATI TŐKE ALLOKÁCIÓJA

6. TÁBLÁZAT: AZ EGYÉNI KOCKÁZATTAL ARÁNYOS MÓDSZER NEM TELJESÍTI A DIVERZIFIKÁLÓ, MAGBELI, ÖSZTÖNZŐ, ERŐSEN

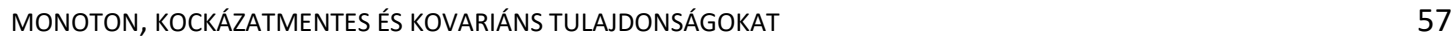

7. TÁBLÁZAT: AZ EGYÉNI KOCKÁZATTAL ARÁNYOS MÓDSZER NEM TELJESÍTI A DEKOMPOZÍCIÓ INVARIANCIA TULAJDONSÁGOT 58

8. TÁBLÁZAT: A BÉTA MÓdSZER NEM TELJESíTI A DIVERZIFIKÁLó, MAGBELI, ÖSZTÖNZŐ, ERŐSEN MONOTON, KOCKÁZATMENTES ÉS

$\begin{array}{lr}\text { KOVARIÁNS TULAJDONSÁGOKAT } & 59\end{array}$

9. TÁBLÁZAT: A NÖVEKMÉNYI MÓDSZER NEM TELESÍTI AZ ÖSZTÖNZÉS ÉS ERŐS MONOTONITÁS TULAJDONSÁGOKAT 61

10. TÁBLÁZAT: A NÖVEKMÉNYI MÓDSZER NEM TELESÍTI A KOCKÁZATMENTES TULAJDONSÁGOT 62

11. TÁBLÁZAT: A NÖVEKMÉNYI MÓDSZER NEM DEKOMPOZÍCIÓ INVARIÁNS 63

12. TÁBLÁZAT: EGY XNP TŐKEALLOKÁCIÓS SZITUÁCIÓ, AHOL A KÖLTSÉGRÉS MÓDSZER NEM MAGBELI ALLOKÁCIÓT EREDMÉNYEZ 67

13. TÁBLÁZAT: XNP ÉS YNP (ZÁRÓJELBEN) TŐKEALLOKÁCIÓS SZITUÁCIÓK, AHOL A KÖLTSÉGRÉS MÓDSZER NEM ÖSZTÖNZŐ 68

14. TÁBLÁZAT: A KÖLTSÉGRÉS MÓDSZER NEM DEKOMPOZÍCIÓ INVARIÁNS 69

15. TÁBLÁZAT. A MARGINÁLIS KOCKÁZATI HOZZÁJÁRULÁS IRÁNYMENTI DERIVÁLTKÉNT ÉRTELMEZVE NEM TELESÍTI A HATÉKONY, $\begin{array}{ll}\text { DIVERZIFIKÁLÓ ÉS MAGBELI TULAJDONSÁGOKAT } & 71\end{array}$

16. TÁBLÁZAT: XNP ÉS YNP TŐKEALLOKÁCIÓS SZITUÁCIÓK, MELYEKBEN A MARGINÁLIS KOCKÁZATI HOZZÁJÁRULÁS NEM ÖSZTÖNZŐ $\begin{array}{ll}\text { ÉS NEM ERŐSEN MONOTON } & 72\end{array}$

17. TÁBLÁZAT: A SHAPLEY-MÓdSZER NEM MAGBELI ÉS NEM DEKOMPOZÍCIÓ INVARIÁNS 75

18. TÁBLÁZAT: A NUKLEOLUSZ MÓDSZER NEM DEKOMPOZÍCIÓ INVARIÁNS

19. TÁBLÁZAT: A VIZSGÁLT TŐKEALLOKÁCIÓS MÓDSZEREK TULAJDONSÁGAI 78

20. TÁBLÁZAT: M-ARÁNYOK ÉS STANDARD HIBÁK AZONOS PORTFÓLIÓ MÉRET, NAGY SZÓRÁS, NORMÁLIS ELOSZLÁS ÉS 95\%-

$\begin{array}{lr}\text { EXPECTED SHORTFALL MELLETT } & 84\end{array}$

21. TÁBLÁZAT: M-ARÁNYOK ÉS STANDARD HIBÁK AZONOS PORTFÓLIÓ MÉRET, NAGY SZÓRÁS, T-ELOSZLÁS ÉS 95\%-EXPECTED

$\begin{array}{lr}\text { SHORTFALL MELLETT } & 85\end{array}$ 
22. TÁBLÁZAT: M-ARÁNYOK ÉS STANDARD HIBÁK KÜLÖNBÖZŐ PORTFÓLIÓ MÉRET, NAGY SZÓRÁS, T-ELOSZLÁS ÉS 95\%-EXPECTED $\begin{array}{lr}\text { SHORTFALL MELLETT } & 86\end{array}$

23. TÁBLÁZAT: AZ EGYES ALKALMAZÁSOKHOZ JAVASOLT MÓDSZEREK ELŐNYEI ÉS HÁTRÁNYAI 110

24. TÁBLÁZAT: AZ ABC ZRT. ÜZLETÁGAI ÁLTAL ELÉRT NETTÓ EREDMÉNY 121

25. tÁblÁZAt: AZ EgYES ÜZLETÁGAK ÉS A TELES ABC ZRT. KOCKÁZATA (99\% EXPECTED SHORTFALL) 121

26. TÁBLÁZAT: A GAZDASÁGI TŐKE ALLOKÁCIÓJA 4 KÜLÖNBÖZŐ MÓDSZER SEGÍTSÉGÉVEL 122

27. TÁBLÁZAT: A RORAC MUTATÓ ALAKULÁSA ÜZLETÁGANKÉNT 123

28. TÁBLÁZAT: M-ARÁNYOK ÉS STANDARD HIBÁK AZONOS PORTFÓLIÓ MÉRET, KIS SZÓRÁS, NORMÁLIS ELOSZLÁS ÉS 95\%-EXPECTED SHORTFALL MELLETT

29. TÁBLÁZAT: M-ARÁNYOK ÉS STANDARD HIBÁK AZONOS PORTFÓLIÓ MÉRET, KIS SZÓRÁS, T-ELOSZLÁS ÉS MAXIMÁLIS VESZTESÉG MELLETT

30. TÁBLÁZAT: M-ARÁNYOK ÉS STANDARD HIBÁK KÜLÖNBÖZŐ PORTFÓLIÓ MÉRET, KIS SZÓRÁS, T-ELOSZLÁS ÉS MAXIMÁLIS VESZTESÉG MELLETT

31. TÁBLÁZAT: M-ARÁNYOK ÉS STANDARD HIBÁK AZONOS PORTFÓLIÓ MÉRET, NAGY SZÓRÁS, NORMÁLIS ELOSZLÁS ÉS 84,14\% 


\section{ÁBRAJEGYZÉK}

1. ÁBRA: AZ EXPECTED SHORTFALL ÉS A FELTÉTELES VAR SZÁMÍTÁSÁNAK KÜLÖNBSÉGE ................................................. 33

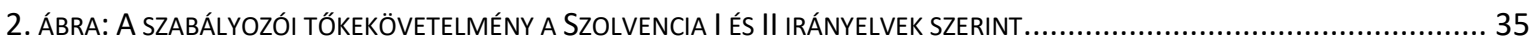

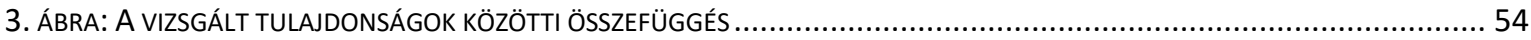

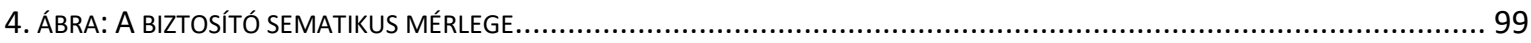

5. ÁBRA: AZ ABC ZRT. EGYES ÜZLETÁGAI ÁLTAL ELÉRT MŰKÖDÉSI EREDMÉNY ................................................... 118

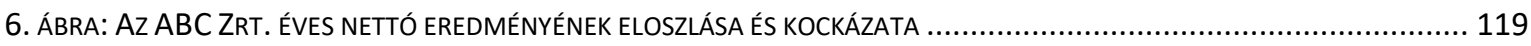




\section{BEVEZETÉS}

Disszertációm témája a pénzügyi szektorban alkalmazott belső tőkeallokáció. A tőkeallokáció a nem várt kockázatok fedezésére szükséges tőkének az egyes üzletágakra, portfólióelemekre, vagy más módon meghatározott egységekre való felosztásának folyamata. A tőkeallokáció gyakorlati oldalról való megközelítése során a pénzügyi vállalatokon belül a biztosítási szektorra koncentrálok, mivel leginkább ebben a szektorban alkalmaznak szofisztikált tőkeallokációs módszereket.

A különböző biztosítási események bekövetkezése sztochasztikus, így a legfejlettebb statisztikai módszerek alkalmazása esetén is elöfordulhat, hogy a beszedett díjak és a tartalékok nem fedezik a biztosítóval szembeni követeléseket. Ilyen esetekben a szavatoló töke biztosítja, hogy a biztosító továbbra is eleget tudjon tenni kötelezettségeinek. Máshogy fogalmazva a szavatoló tőke az események nem várt, kedvezőtlen alakulása esetén felmerülö veszteségek fedezésére szolgál. Bár e szavatoló tőke egyaránt védelmet nyújt bármely üzletág által elszenvedett veszteséggel szemben, számos okból fontos mégis tudni, hogy az egyes üzletágak milyen mértékben járulnak hozzá a biztositó tőkeigényéhez. Tőkét tartani költséges, e költségnek az allokálása pedig igen fontos tényező az üzletágak és egyes termékportfóliók teljesítményének értékelése, termékárazási és bizonyos stratégiai döntések (felvásárlások, összeolvadások, új üzletág indítása, vagy meglévő megszüntetése) során. A biztosítótársaságok jellemzően üzletágakra, leányvállalatokra, termékekre vagy termékcsoportokra allokálják a tőkéjüket, de találkozhatunk különböző földrajzi régiókra, vagy akár értékesítési csatornákra történő felosztással is. 
A probléma nem új keletü, különösen aktuálissá teszi azonban a biztosítótársaságok esetében nemrég, 2016. január 1-gyel életbe lépett Szolvencia II $^{1}$ direktíva. Az irányelv első pillére a tőke és tőkeszükséglet számítására hoz új szabályokat (így megváltozhat maga az allokálandó tőke mennyisége). A második pillérben elöírt saját kockázat és szavatolótőke értékelés (a továbbiakban ORSA, Own Risk and Solvency Assessment) folyamat keretében pedig maga a tőkeallokációs folyamat is a szabályozó ellenőrzése alá kerül (az integrált vállalati kockázatkezelési rendszerre vonatkozó elvárásokon keresztül). Maume-Deschamps et al. (2016) tanulmányát idézve: „, A második pillér ORSA gyakorlata a tökeallokációt fontos kérdéssé teszi minden biztositó számára [...]”. Az integrált vállalati kockázatkezelési rendszerek $^{2}$ (Enterprise Risk Management, ERM) fejlesztése a biztosítók számára nem csak a Szolvencia II elö́rásai miatt kiemelten fontos feladat. Ahogyan arra a McKinsey felhívja a figyelmet (Bongiovanni et al., 2016), a fejlettebb vállalati kockázatkezelési rendszerrel rendelkező biztosítók szignifikánsan jobban teljesítettek társaiknál a válság (2008 és 2009) során. Ezt felismerve maguk a biztosítók is jelentős erőforrásokat kezdtek áldozni ERM rendszereik fejlesztésére, melyeknek pedig fontos alkotóeleme a tőkeallokáció, hiszen a teljesítményértékelésen keresztül a biztosító egy-egy üzletága (leányvállalata, portfóliója) által elért hozamot (ami az üzlet jövedelmezőségét jellemzi) veti össze az adott egységre allokált tőkekövetelménnyel (ami pedig egy fontos kockázati mutató).

A biztosítási szektorban tehát a Szolvencia II szabályozás bevezetésével párhuzamosan a tőkeallokáció egyre nagyobb szerephez jut napjainkban Európában, miközben az USA-ban a szabályozó hatóság már korábban is kötelezővé tette a biztosítók számára a tőkeallokációt.

A tőkeallokáció kérdése régóta foglalkoztatja az akadémiai világot is. Ez kevéssé meglepö, hiszen egy matematikailag is jól megfogalmazható, távolról sem triviális probléma, amely

\footnotetext{
${ }^{1}$ Az Európai Parlament és a Tanács 2009/138/Ek Irányelve

${ }^{2}$ Ld. pl. McKinsey\&Company (2014)
} 
számos különböző megközelítésben vizsgálható: a játékelmélet eszközeivel (pl. Denault, 2001; Csóka et al., 2009, Csóka és Pintér, 2016), opcióárazási (pl. Myers és Read, 2001; Sherris, 2006; Kim és Hardy, 2007) vagy egyéb statisztikai megközelítésben (pl. Kalkberener, 2005; Homburg és Scherpereel, 2008; Buch és Dorfleitner, 2008). A tőkeallokációs probléma megoldására számtalan különböző módszer áll az alkalmazók rendelkezésére, azonban részben pont emiatt az elméleti kutatások és a gyakorlati alkalmazás között egyelöre elég nagy a távolság.

Ahogy Kim és Hardy (2007, p23) írja, ,, a tökeallokációs módszerek nagyobb részt axiómák alapján kerültek kialakitásra, nem pedig [a felhasználás ${ }^{3}$ ] céljai szerint, és kevés kutatási eredmény áll rendelkezésre a célok fényében történő alkalmazásra vonatkozóan”. Hasonló véleményt fogalmaz meg Meyers (2005, p26) is: „Sajnos kiderült, hogy a gazdasági allokáció nem ekvivalens az axiomatikus allokációval”. A disszertációban emiatt olyan, az irodalomban igen ritka megközelítést alkalmazok (Vrieze és Brehm, 2003; Zec, 2014, illetve Balogh, 2006 a bankokra koncentrálva), amely a tőkeallokáció elméleti és gyakorlati oldalával egyaránt foglalkozik; a módszertani kérdések vizsgálata mellett a módszerek gyakorlati használatával kapcsolatban is támpontokat adok.

A disszertáció legfontosabb fejezetei a 2., 3. és 4. részekben találhatóak, az 1. rész felvezetésként szolgál a később tárgyaltakhoz: bevezetem a kockázat mérésével kapcsolatos szükséges fogalmakat, bemutatom a később alkalmazott kockázatmértékeket, illetve a szükséges tőkefogalmakat is ebben a részben tisztázom.

A 2. rész (mely Bátyi Tamással, Csóka Péterrel és Pintér Miklóssal való közös munkánk eredménye) tekinthető a disszertáció „elméleti részének”, itt a tőkeallokáció módszertani kérdésével foglalkozunk, azonban már az itt közölt eredmények is bizonyos mértékben

\footnotetext{
${ }^{3}$ A fordító kiegészítése
} 
gyakorlat-orientáltak. Tíz fontos követelménynek való megfelelés szempontjából vizsgálunk hét, az irodalomban gyakran előforduló, illetve a gyakorlatban alkalmazott módszert, melyek a következők: egyéni kockázattal arányos módszer (Hamlen et al., 1977); béta módszer (ld. pl. Homburg és Scherpereel, 2008); növekményi módszer (ld. pl. Jorion, 2007); költségrés módszer (Tijs és Driessen, 1986); marginális kockázati hozzájárulás - mint iránymenti derivált (Cherny és Orlov, 2011), és mint parciális derivált, más néven Euler módszer (1d. pl. Denault, 2001, vagy Buch és Dorfleitner, 2008); a Shapley-módszer (Shapley, 1953) és a nukleolusz módszer (Schmeidler, 1969). A módszerek vizsgálata során az egyes követelmények teljesítését csak az adott módszer értelmezési tartományán várjuk el: vannak módszerek, melyek nem mindig definiáltak, azaz nem teljesítik az első vizsgált tulajdonságot, a teljes értelmezési tartományon való definiáltságot (mindig értelmezettség). A további kilenc vizsgált tulajdonságot két csoportba sorolhatjuk. Az első csoport tulajdonságai az egyes alegységekből álló halmazok (koalíciók) kockázataival foglalkozó kooperatív játékelmélethez kapcsolódnak: magbeliség; diverzifikáció; erős monotonitás; hatékonyság; egyenlően kezelés. A második csoport tulajdonságai közvetlenül a portfólión definiáltak, a kockázatmérték használata nélkül: az ösztönzés, a kockázatmentes allokáció, a kovariancia és a dekompozíció invariancia.

Minden módszer és tulajdonság esetében bizonyítással vagy ellenpéldával mutatjuk meg, hogy az adott módszer teljesíti-e a szóban forgó tulajdonságot. Az analitikus eredményeinket összegző táblázat hasznos támpontként szolgálhat a gyakorlati alkalmazóknak a módszerek közötti választásban, továbbá segítséget nyújthat abban is, hogy egy adott módszer alkalmazása esetén milyen esetleges problémára kell felkészülni az alkalmazás során.

Ha egy módszer egy adott tulajdonságot nem teljesít, az még nem biztos, hogy problémát jelent az alkalmazás során, ha a tulajdonság megsértése csak bizonyos elméletileg lehetséges, ám a gyakorlatban nem releváns esetekben fordul elő. Emiatt a magallokáció 
követelményének teljesítését szimuláció segítségével is vizsgáljuk: legfeljebb kilenc alegységet tartalmazó portfóliók esetén, véletlenszerüen generált tőkeallokációs szituációkban ${ }^{4}$ milyen arányban eredményez magbeli elosztást az egyéni kockázattal arányos, a béta, a növekményi, a költségrés és a Shapley-módszer. Mivel a nukleolusz módszer, illetve a szimulált környezetben a marginális kockázati hozzájárulás mindkét típusa mindig eleget tesz a magbeliség követelményének, ezek nem képzik tárgyát a szimulációs vizsgálatnak. Megmutatjuk, hogy legjobban a költségrés módszer teljesít: jellemzően 90\% feletti arányban ad magbeli elosztást, bár ez egyes esetekben akár 30\%-ig is lemehet. Általában a magbeli elosztások aránya nagyban függ a szimuláció paramétereitől, de minden esetben csökken az alegységek számának csökkenésével.

A 3. rész már teljes mértékben a gyakorlati felhasználásra koncentrál, ugyanakkor épít a 2. rész előbb említett eredményére is, mely szerint az egyes módszerek által eredményezett elosztás tulajdonságai igen nagymértékben függenek az alap probléma paramétereitől. Ebben a részben - egyfajta útmutatóként szolgálva - a tőkeallokációs problémának a szakirodalomban megszokott, igen absztrakt megfogalmazását a biztosítóknál az implementáció során felmerülő gyakorlati kérdésekre fordítom le, ezzel segítséget nyújtva az elméletileg lehetséges módszerek közötti eligazodásban. Bemutatom a lehetséges alkalmazásokat, vagyis azt, hogy miért fontos, mire használják a biztosítótársaságok a tőkeallokációt. Ez meghatározó, hiszen mint látni fogjuk, végső soron mindig a felhasználás célja szerint kell az alkalmazott módszert kiválasztani, mivel a tőkeallokációs problémának nincs univerzális, minden helyzetben alkalmazható legjobb megoldása. Ehhez a választáshoz igyekszem praktikus támpontokat adni a lehetséges módszerek

\footnotetext{
${ }^{4}$ Egy-egy tőkeallokációs szituáció összetevői az alábbiak: az alegységek, a portfólióik, és egy koherens kockázatmérték.
} 
csoportosításával, illetve annak meghatározásával, hogy a felhasználás céljai szerint mely módszertípust érdemes alkalmazni.

A 4. részben végül egy esettanulmány segítségével szeretném még kézzelfoghatóbban bemutatni a tőkeallokációt, illetve annak egy lehetséges felhasználását. Az esettanulmányban az $\mathrm{ABC}$ Zrt., egy fiktív biztosítótársaság példáján keresztül természetesen sok szempontból egyszerüsítéseket alkalmazva - mutatom be, hogyan alkalmazhat egy biztosító tőkeallokációs módszereket az egyes üzletágainak teljesítményének értékelésére. 


\section{RÉSZ: TŐKE, KOCKÁZATMÉRÉS}

A pénzügyi intézményekben a kockázat mai értelemben vett mérésével csak az elmúlt néhány évtizedben kezdtek komolyabban foglalkozni, a modern kockázatkezelés „születését” az irodalomban 1950-1960 körülre datálják (Dionne, 2013). Ugyanakkor az első biztosítás jellegü ügyletek már jóval időszámításunk előtt köttettek: a legkorábbi utalást Hamurappi törvénykönyve tartalmazza. A törvénykönyv olyan kölcsönökről számol be, amelyek mellé többlet díj ellenében biztosítást is köthettek a tengeri kereskedők, azaz amennyiben hajójuk elsüllyedt, a felvett kölcsönt nem kellett visszafizetniük. Később, a középkorban az egyház megtiltotta a kamat ellenében történő hitel nyújtását, IX. Gergely Pápa azonban a különféle kockázatok átvállalását (s ezért díj felszámítását) kimondottan külön engedélyezte: a történelem során ekkor vált el elöször a biztosítás, mint termék a hitelügylettől. Néhány száz év elteltével, a 18. században jelentek meg Európában az első biztosító részvénytársaságok, amelyek az egymás közötti kölcsönös kármegosztást alkalmazták kockázataik csökkentésére. Alig száz évvel később, az 1800-as évek közepén ez a típusú kockázatmegosztás elégtelennek bizonyult, mikor Németországban az 1842-es hamburgi nagy tüz, illetve Svájcban az 1861-es glarusi nagy tüz számos biztosítótársaság csődjét okozta, s rövid időn belül létrejöttek az első viszontbiztosítók: a Cologne Re, illetve a Swiss Re. A biztosítási szektoron kívül a Második Világháborút követően erősödött meg az igény a pénzügyi kockázatkezelés iránt. Az értékes eszközöket, készleteket birtokló nagyvállalatok ekkoriban kezdtek saját biztosítás jellegü termékeket fejleszteni.

Az 1900-as években ${ }^{5}$ eközben elkezdődött a pénzügy, mint önálló tudományterület fejlődése is. Az első nagy mérföldkőnek Louis Bachelier 1900-as műve (Davis és Etheridge, 2006)

\footnotetext{
${ }^{5}$ Az összefoglaló további részében Dionne (2013) munkájára támaszkodunk, míg az előző bekezdésben az elsődleges forrás a http://www.theactuary.com/archive/old-articles/part-3/reinsurance-3A-a-brief-history/ oldal volt.
} 
tekinthető. A pénzügyi termékek árfolyam-mozgásaira irányulóan az 1930-as éveket követően kezdődtek komolyabb kutatások. Az USA-ban létrejöttek az első kockázatkezeléssel foglalkozó társaságok (American Finance Association, American Risk and Insurance Association), s elindult a Journal of Insurance folyóirat (melyet 1964-ben neveztek át Journal of Risk and Insurance-ra). Az 50-es, 60-as évek ismét igen nagy fejlődést jelentettek, többek között Markowitz, Lintner és Sharpe munkásságának eredményeként a modern portfólióelmélet és a CAPM (Capital Asset Pricing Model, magyarul: tőkepiaci árfolyamok modellje) születésével.

Az 1970-es években indult meg a derivatív jellegü pénzügyi termékek robbanásszerü fejlődése. E termékek célja kezdetben a biztosításokéhoz nagyon hasonló volt: vagyis a nagymértékű veszteségek elkerülése érdekében hozták létre és vásárolták ezeket, azonban a biztosításoktól egy nagyon fontos tulajdonság megkülönböztette őket: ezek az ügyletek egy kereskedett alaptermékhez kötöttek (pl. egy részvény, egy tőzsdén kereskedett áru), szemben a biztosításokkal, melyek esetében maga a biztosítási esemény teljesen más jellegü (nem kereskedett), pl. haláleset, betegség, tüzeset, vagy egyéb baleset.

1973-ban jelent meg Black és Scholes „forradalmi” jelentőségű opcióárazási modellje (Black és Scholes, 1973). A tanulmány publikálását előbb több lap is elutasította, olyannyira újdonságnak számítottak a benne leírtak, végül a Journal of Political Economy folyóirat jelentette meg. Még ugyanebben az évben publikálta Merton az árazási modell általánosított, európai opciókra ${ }^{6}$ is alkalmazható változatát a Bell Journal of Economics and Management Science címü folyóiratban (Merton, 1973). Szintén 1973-ban létrejött a Chicago Board of Options Exchange, a világ első, s a mai napig legnagyobb forgalmat lebonyolító tőzsdéje, ahol opciókkal kereskednek. A következő évtizedekben a derivatív termékek iránti kereslet

\footnotetext{
${ }^{6}$ Olyan opció, amely kizárólag a lejárat időpontjában lehívható - szemben az amerikai opcióval, melynek esetében az opciós jog a lejárat időpontjáig bármikor gyakorolható.
} 
folyamatosan növekedett, ahogyan a piaci szereplők számára is egyre inkább központi kérdéssé vált a tevékenységükkel kapcsolatos kockázat fedezése.

A kockázatkezelés, mint kutatási terület fejlődésének szintén nagy lökést adott néhány, a 20. század utolsó évtizedeiben bekövetkezett esemény is. A legfontosabbak közé sorolható a Bretton Woods-i árfolyamrendszer ${ }^{7}$ összeomlása 1971-ben, illetve az olajár-robbanás az 1970-es években. Jelentős mérföldkőnek tekinthető a hírhedt „Fekete Hétfo”” is (1987. október 19-én az egyik legnagyobb amerikai részvényindex, a Dow Jones 23\%-ot zuhant egyetlen nap alatt), illetve az 1998-as orosz válság is, melyek mind piaci kockázati eseménynek tekinthetők. Ugyanakkor fontos megemlíteni néhány igen nagy jelentőségü müködési kockázati eseményt is: az amerikai Orange megye csődje 1994-ben (egy megyei tisztségviselö, hatalmas tőkeáttétellel járó befektetési stratégiájának köszönhetően közel 2 milliárd dollárt veszített; a tisztségviselőt csalásért 14 évre elítélték, ld. pl. Jorion 2007); a brit Barings Bank csődje 1995-ben (amelyet a pénzintézet szingapúri leányának vezetőjeként az akkor 28 éves Nick Leeson idézett elő, aki tőzsdei spekulatív ügyleteivel - melyek veszteségét egy titkos számla segítségével próbálta eltitkolni - végül körülbelül 850 millió fontos veszteséget okozott, ld. Greener, 2006); vagy a 2001-es Enron botrány (az energiaipar egyik fontos szereplőjének számító Enron Corporation pénzügyi igazgatójának vezetésével a cégben hosszú időn keresztül meghamisították a pénzügyi jelentéseket, hogy a bedőlt projektek veszteségeit láthatatlanná tegyék, amely végül mind a vállalat csődjéhez, mint a céget auditáló Arthur Andersen könyvvizsgálati üzletágának bezárásához vezetett, ld. pl. Gordon, 2002).

A kockázatkezelés tehát egyre inkább a pénzügyi világ figyelmének fókuszába került, s az alkalmazott matematikai eszköztár is jelentős fejlődésnek indult. A nagy befektetési bankok

\footnotetext{
${ }^{7}$ Az amerikai dollár (s a rendszerhez csatlakozott többi állam valutáinak) kötött árfolyamon történő aranyra váltása, melyet az Egyesült Államok 1971-ben felfüggesztett.
} 
jelentős erőforrást fektettek kockázatkezelési rendszereik fejlesztésébe, és néhányuk azt külső szereplők számára is elérhetővé tette: a JP Morgan 1994-ben dobta piacra a piaci kockázatok kezelésére szolgáló RiskMetrics, majd 1997-ben a hitelezési kockázatok kezelésére született CreditMetrics modellt. Nagyban köthető a RiskMetrics modell alkalmazásához a VaR (Value at Risk, magyarul kockáztatott érték, ld. az 1.1.3.2 fejezetben) módszer elterjedése, amely széles körben ismertté és elfogadottá vált a pénzügyi szektorban. Számtalan további kockázatmérték, rengeteg módszertan és szoftver született a kockázat mérésére, és a szabályozók is egyre nagyobb hangsúlyt fektettek a pénzügyi vállalatok által vállalt kockázat korlátozására és szofisztikált mérésére.

Többek közt a fent említett müködési és piaci kockázati eseményeket - s több nagy bank és egyéb vállalat csődjét - követően a tőkekövetelmény számítás is egyre hangsúlyosabb szabályozói kérdéssé vált. A bankszektorban az 1988-as Bázel I szabályozást jelentősen továbbfejlesztette és (a müködési és piaci kockázatok figyelembe vételével) kiegészítette a 2004-es Bázel II, majd a Bázel III egyezmény. A biztosítási szektor bizonyos szempontból előrébb járt a szabályozásban: a Szolvencia I irányelv már 1973 óta hatályban volt, de a kockázatérzékenyebb értékelést előíró (és a Bázel II/III szabályozással analóg módon már három pillérre épülő) Szolvencia II irányelv életbelépése 2016-ig váratott magára (ld. majd az 1.2.1 fejezetben).

A tanulmány 1. részének felépítése a továbbiakban a következő. Az 1.1. fejezetben a kockázat mérésére rendelkezésre álló lehetséges kockázatmértékeket tekintem át röviden. Az áttekintés távolról sem teljes körü, célom elsősorban az, hogy a tanulmány további részeiben alkalmazott kockázatmértékeket bemutassam. Az 1.2. fejezetben a különböző lehetséges tőkefogalmakkal, és a biztosítókra vonatkozó tőkekövetelményekkel foglalkozom. 


\subsection{A KOCKÁZAT MÉRÉSE}

A biztosítók alaptevékenysége a kockázatok (át)vállalásán alapul, de a kockázatvállalás hasonlóan központi szerepet játszik az egyéb pénzügyi intézmények esetében is (pl. bankok esetében legmeghatározóbb a hitelezési kockázat, alapkezelöknél a piaci kockázat). A kockázatok kezelésére ma már igen széles eszköztár áll a pénzügyi vállalatok rendelkezésére. A kockázatkezeléssel erre specializálódott szakemberek foglalkoznak, jellemzően a cég struktúrájában elkülönült szervezeti egységben. A terület általában erős IT támogatottsággal is rendelkezik: a cégek szofisztikált kockázatkezelési szoftvereket, vagy belső fejlesztésü modelleket alkalmaznak. Számtalan különböző tartalmú és különbözö célközönségnek készülő kockázatkezelési riport születik nap mint nap, melyek segítségével ideális esetben a vezetőség is naprakész információval rendelkezik a vállalt kockázatokról.

A bankok és biztosítók által alkalmazott kockázatkezelési módszerek között egyaránt jelen vannak a kvantitatív és kvalitatív eljárások. A kvantitatív módszerek (melyek egy, vagy néhány mutatószám segítségével jellemzik a vállalt kockázatot) természetesen nagyon fontos információt hordoznak, de kizárólag ezekre támaszkodni veszélyes, ahogyan erre a 2007-2008-as válság is felhívta a figyelmet. A válság során a pénzügyi intézmények által elszenvedett hatalmas veszteségekhez ugyanis sokak véleménye szerint részben a VaR (kockáztatott érték, Value at Risk) kockázatmérték nem megfelelő alkalmazása vezetett. A válság során a VaR alkalmazása sokaknak hamis biztonságérzetet adott, ami egy fontos tényező volt abban, hogy az elszenvedett veszteségek ilyen hatalmas mértékủek legyenek. Ahogyan a későbbiekben látni fogjuk, a VaR kockázatmértékkel szemben több kritikát is meg lehet fogalmazni, azonban a konkrét mérték tulajdonságaitól függetlenül is elmondható, hogy egyetlen mérőszámra támaszkodni a kockázatok értékelése során nem célszerủ. Fontos tehát, hogy a kvalitatív kockázatértékelési módszerek jelentőségéről se felejtkezzünk meg - 
legyen az akár egy kockázati térkép, a kockázatvállalási étvágy („risk appetite”) meghatározása, egy különböző kockázati szintekhez kötött korai figyelmeztető mechanizmus, vagy akár csak a kockázatkezelők szubjektív, szakértői kockázatértékelése. Ugyanakkor tény, hogy a kockázatok számszerüsítésére alkalmazott kockázatmértékek elengedhetetlen, alapvető építőkövei a kockázatkezelésnek.

Kockázatmérték alatt azt a leképezést értjük, amely egy valós számot rendel a portfólió nyereségét/veszteségét leíró valószínüségi változóhoz. Ez a számot úgy is értelmezhető, mint azt a készpénz mennyiség, melyet a portfólióhoz adva a portfólió kockázatossága elfogadható lesz a szóban forgó kockázatmérték mellett. A következő alfejezetekben előbb néhány szükséges jelölést vezetek be, hogy formálisan is definiálni tudjam a kockázatmérték fogalmát, majd a koherens kockázatmérés axiómáit veszem sorra, ezt követően pedig a leggyakrabban alkalmazott kockázatmértékeket, s ezek fontosabb tulajdonságait mutatom be.

\subsubsection{AZ ALKALMAZOTT JELÖLÉSEK}

Mivel a 2. részben Balog et al. (2017) cikkének eredményeit közlöm, a konzisztencia jegyében az egész disszertációban az ott alkalmazott jelöléseket használom.

Feltesszük, hogy egy-egy pénzügyi egység (portfólió) által elért hozamot (veszteséget) véletlen valószínűségi változók írják le a $(\Omega, \mathcal{M}, P)$ diszkrét valószínűségi mezőn, ahol $\Omega \mathrm{a}$ lehetséges kimenetelek halmaza, $\mathcal{M}$ jelöli $\Omega$ összes lehetséges részhalmazát, $\mathrm{P}$ pedig egy valószínüség eloszlás $(\Omega, \mathcal{M})$-n. A $(\Omega, \mathcal{M}, P)$-n értelmezett valószínüségi változók halmaza X. Mivel véges számú lehetséges kimenetel van, $X: \Omega \rightarrow \mathbb{R}$ valószínüségi változó tekinthető egy $s$ elemű realizációs vektornak is, ahol $s$ a lehetséges világállapotok számát jelöli. Jelölje tehát $X_{i} \in \mathbf{X}$ az $i$ egység realizációs vektorát, amely tehát az egyes világállapotokban 
megadja az egység által adott idő alatt elért profitot (a negatív értékek veszteséget jelentenek), azaz $X_{i}^{\omega_{j}}$ az $i$ egység kifizetését jelenti az $\omega_{j} \in \Omega$ világállapotban. A továbbiakban két tetszőleges realizációs vektor, $Y$ és $X$ vonatkozásában $Y \geq X$ azt jelenti, hogy minden lehetséges $\omega_{j} \in \Omega$ világállapotban $Y^{\omega_{j}} \geq X^{\omega_{j}}$.

A $\rho: \mathbf{X} \rightarrow \mathbb{R}$ függvényt kockázatmértéknek nevezzük. A kockázatmérték minden valószínűségi változóhoz egy valós számot rendel, megadja az egyes portfóliók kockázatát. Az így értelmezett kockázatot tekinthetjük annak az összegnek - tőke -, amelyet a portfólióhoz adva annak kockázata elfogadhatóvá válik. A kockázatmértékek között kiemelt szerepet töltenek be a koherens kockázatmértékek, melyeket a következő alfejezetben definiálok.

\subsubsection{KOHERENS KOCKÁZATMÉRÉS}

Mind az irodalomban, mind pedig a gyakorlatban számos különböző kockázatmértékkel találkozhatunk. Ezek összevetése, értékelése kapcsán talán a legfontosabb, az akadémiai és a pénzügyi világban egyaránt elfogadott referencia pontnak a koherencia Artzner és szerzőtársai (1999) által definiált négy követelménye tekinthető. A konkrét kockázatmértékek sorra vétele előtt tekintsük át tehát a koherens kockázatmérés követelményeit. A fogalom elméleti alapjairól bővebben Csóka et al. (2007), illetve Acerbi és Scandolo (2008) cikkében, a gyakorlati alkalmazásairól a Bázeli Bankfelügyelet tanulmányában (BCoBS, 2014) olvashat az érdeklődő.

1.1.1. definíció (Artzner et al., 1999). A $\rho: X \rightarrow \mathbb{R}$ függvényt koherens kockázatmértéknek nevezzük, amennyiben teljesiti a következö axiómákat:

- Monotonitás: minden $X_{1}, X_{2} \in \mathbf{X}-r e$, amennyiben $X_{1} \leq X_{2}, \rho\left(X_{1}\right) \geq \rho\left(X_{2}\right)$.

- Szubadditivitás: minden $X_{1}, X_{2} \in \mathbf{X}-r e \rho\left(X_{1}+X_{2}\right) \leq \rho\left(X_{1}\right)+\rho\left(X_{2}\right)$. 
- Pozitiv homogenitás: minden $X_{1} \in \mathbf{X}$ és $h \in \mathbb{R}_{+}-r a \rho\left(h X_{1}\right)=h \rho\left(X_{1}\right)$.

- Transzláció invariancia: minden $X_{1} \in X$ és $a \in \mathbb{R}-r e, \rho\left(X_{1}+a \chi_{\Omega}\right)=\rho\left(X_{1}\right)-a$, ahol $\chi_{\Omega}$ egy olyan vektor $\mathbb{R}^{\Omega}-n$, melynek minden koordinátája 1.

A fenti axiómák magyarázata sorra a következö.

A monotonitás azt a meglehetősen kézenfekvő elvárást fejezi ki, hogy ha egy adott $X_{2}$ portfólió hozama soha nem rosszabb, mint $X_{1}$-é, akkor a kockázata se legyen nagyobb. Vagyis, ha egy portfólió minden lehetséges kimenetel esetén legalább akkora profitot termel, mint egy másik portfólió, akkor a kockázata ne legyen magasabb a másik portfólióénál.

A szubadditivitás azt jelenti, hogy két portfólió (üzletág, stb.) egyesítése esetén a kockázat nem növekszik. Ha a szubadditivitás nem teljesülne, akkor egy olyan befektető, aki az $X_{1}$ és $X_{2}$ portfóliókat is tartani szeretné, jobban járhatna, ha két külön számlán tartaná a két befektetést, mint egy közös számla esetén. A szubbaditivitás által válik lehetővé a diverzifikáció: $X_{1}$ és $X_{2}$ egyesítése esetén az új kockázat, $\rho\left(X_{1}+X_{2}\right)$ alacsonyabb lehet, de magasabb nem a két egység külön-külön számított kockázatának összegénél, $\rho\left(X_{1}\right)+$ $\rho\left(X_{2}\right)$-nél.

A pozitív homogenitás követelménye is világos: konstansszorosára növelve az adott kockázatos portfóliót a kockázat is konstansszorosára nő. A pozitív homogenitás elvárása azt is jelenti tehát, hogy a portfólió kockázata egyenes arányban változik annak méretével. Az alábbiakban röviden kitérünk rá, hogy bár elméletben ez igen logikusan hangzik, de a gyakorlatban nem feltétlenül igaz, amennyiben az adott piacon a likviditási kockázattal is számolnunk kell.

Végül a transzláció invariancia elvárása azt fejezi ki, hogy egy kockázatmentes eszközt (amelynek hozamát tehát elöre biztosan ismerjük, legyen $a$ ) adva bármely más portfólióhoz, annak a kockázata a kockázatmentes eszköz hozamával, $a$-val csökkenjen. Vagyis például 
ha egy adott befektetett portfólióhoz készpénzt adunk, akkor a befektetésünk kockázata pontosan a készpénz mennyiségével kell, hogy csökkenjen.

Bár a koherens kockázatmértékek széles körben elfogadottak, azonban fontos tisztában lennünk azzal is, hogy ezek a kockázatmértékek sem „hibátlanok”. A leggyakrabban felmerülő kritika a koherens kockázatmértékekkel szemben, hogy egy fontos jelenséget: a likviditási kockázatot nem kezelik megfelelöen. Többek között Acerbi és Scandolo (2008) hívta fel arra a figyelmet, hogy a gyakorlatban a portfólió mérete nagyban befolyásolja annak kockázatát, hiszen a portfólió méretének többszörösére növelése sok esetben a méret növekedésénél nagyobb mértékben növeli annak a kockázatát (jellemzően, ha az adott portfólió mérete már nem elhanyagolható a teljes piac méretéhez képest) a likviditási kockázat jelenléte miatt. Amennyiben pedig elfogadjuk, hogy a valóságban egy kétszer nagyobb portfólió kockázata az eredeti portfólió kockázatának több, mint kétszerese is lehet (mert pl. nehezebb, több idő értékesíteni, készpénzzé tenni azt), akkor a koherens kockázatmérés axiómái közül kettő, a pozitív homogenitás és a szubadditivitás is sérül. Acerbi és Scandolo (2008) viszont egyszerü megoldást is kínál a probléma feloldására azzal, hogy a portfólió értékét módosítják (attól függően, hogy mi a cél az adott portfólióval), melyet a likviditási politika segítségével számszerüsítenek, ami tehát annak függvényében határozza meg a portfólió értékét, hogy pl. csak tartani akarjuk, vagy szükséges lehet egy részét likvidálni, készpénzzé tenni. Erre a módosított portfólióértékre pedig továbbra is logikusan elvárható a koherens kockázatmérés négy axiómájának teljesítése.

\subsubsection{A LEGGYAKRABBAn ALKALMAZOTT KOCKÁZATMÉRTÉKEK}

Az alábbiakban - természetesen a teljesség igénye nélkül - lehetséges alternatívákat mutatok be a kockázat számszerüsítésére használható kockázatmértékekre. Csak néhány, a gyakorlatban gyakran alkalmazott kockázatmértékkel foglalkozom, melyek közül a 
következő részekben elsősorban a VaR és az Expected Shortfall kockázatmértékeket fogom alkalmazni. Kimondottan a biztosítási szektorban alkalmazott kockázatmértékekkel kapcsolatban részletesebb összefoglalót ad Kaye (2005), Hardy (2006), Goldfarb (2010), vagy Zec (2014).

\subsubsection{Szórás}

Az egyik legrégebben alkalmazott kockázatmérték a valószínűségszámításból átvett, ugyanakkor a nem-akadémiai közönség számára is ismerős szórás (jelöljük D-vel), melynek formális definíciója a következö:

$$
D(X)=\sqrt{E\left(X^{2}\right)-E^{2}(X)},
$$

ahol $E(X)$ szokás szerint az X változó várható értékét jelöli.

A szórást viszonylag gyakran alkalmazzák a kockázat mérésére, ugyanakkor fontos tisztában lenni azzal, mennyire limitált az információtartalma. A szórás az eloszlást egyetlen számban jellemzi, s könnyen konstruálható két meglehetősen különböző eloszlású valószínűségi változó, melyek szórása megegyezik. A biztosításokhoz kapcsolódó eloszlások az esetek túlnyomó többségében távolról sem normálisak, nem is szimmetrikusak, így a szórás önmagában nem jellemzi jól az eloszlást, mellette fontos a harmadik, negyedik momentumok ismerete is (ld. pl. Kaye, 2005).

A szórás a koherencia axiómáinak való megfelelés szempontjából sem teljesít jól, kettőt is megsért közülük: nem monoton, és nem is transzláció invariáns. Ennek bizonyítására tekintsük a következő példát.

1.1.2 példa. Tekintsük a lenti $X_{1}, X_{2}, Y_{1}, Y_{2} \in X$ portfóliókat, és legyen a lehetséges kimenetelek halmaza $\Omega=\left\{\omega_{1}, \omega_{2}, \omega_{3}, \omega_{4}\right\}$, P pedig olyan, hogy $P=P\left(\left\{\omega_{1}\right\}\right)=$ $P\left(\left\{\omega_{2}\right\}\right)=P\left(\left\{\omega_{3}\right\}\right)=P\left(\left\{\omega_{4}\right\}\right)=1 / 4$. A kockázatot a szórással mérjük. A különböző 
világállapotokban az egyes portfóliók értékeit, illetve az ezekből számított kockázatot a lenti 1. táblázat tartalmazza.

1. táblázat: A szórás nem koherens

\begin{tabular}{|c|c|c||c|c|c|}
\hline$\Omega / X_{S}$ & $X_{1}$ & $X_{2}$ & $\Omega / Y_{S}$ & $Y_{1}$ & $Y_{2}$ \\
\hline$\omega_{1}$ & -1 & 0 & $\omega_{1}$ & -1 & 0 \\
\hline$\omega_{2}$ & -1 & 0 & $\omega_{2}$ & -1 & 0 \\
\hline$\omega_{3}$ & 0 & 2 & $\omega_{3}$ & 0 & 1 \\
\hline$\omega_{4}$ & 0 & 2 & $\omega_{4}$ & 0 & 1 \\
\hline \hline$D\left\{X_{S}\right\}$ & 0,5 & 1 & $D\left\{Y_{S}\right\}$ & 0,5 & 0,5 \\
\hline
\end{tabular}

A monotonitást vizsgálva látjuk, hogy bár $X_{2}$ kifizetése mindig meghaladja $X_{1}$-ét, a két portfólió szórása: $D\left(X_{1}\right)=0,5$, viszont $D\left(X_{2}\right)=1$, azaz $X_{2}$ kockázata meghaladja $X_{1}$-ét, tehát ez a követelmény nem teljesül. Szintén látható, hogy $Y_{2}=Y_{1}+1$, ugyanakkor a transzláció invariancia teljesülése esetén $D\left(Y_{2}\right)=D\left(Y_{1}+1\right)=D\left(Y_{1}\right)-1=-0,5$ állna fenn, ami láthatóan nem igaz.

\subsubsection{Kockáztatott érték (Value at Risk, VaR)}

Napjainkban továbbra is talán a legelterjedtebb módszer a kockázatott érték, ismertebb nevén VaR (Value at Risk). Az adott $\alpha \in[0,1)$ szignifikancia szint mellett számított VaR egyszerủen $X$ eloszlásának az adott $\alpha$ mellett számított kvantilisének ellentettje:

$$
\operatorname{VaR}_{\alpha}(X)=-\inf \{x \in \mathbb{R}: P(X \leq x) \geq 1-\alpha\}
$$

Tehát például $\alpha=0.995$ esetén azt értéket kapjuk, amelyet meghatározott időtávon (jellemzően 1 nap, 10 nap, 1 év) 99,5\%-os valószínűséggel (ami gyakran alkalmazott szignifikancia szint a gyakorlatban) nem fog meghaladni a veszteségünk. 
A VaR kockázatmérték alkalmazása az 1990-es években terjedt robbanásszerüen a pénzügyi szektorban, különösen a befektetési bankok, alapkezelők körében. (Fontos megjegyezni, hogy a VaR-t alapvetően kereskedett termékek kockázatának mérésére vezették be, szemben például az előzőekben tárgyalt szórással.) A legnagyobb szerepe a VaR népszerüsítésében a JP Morgan RiskMetrics modelljének volt, amely egy VaR-ra épülő piaci kockázatkezelési szisztéma. Nagyon hasonló kockázatmértéket, a maximális várható éves veszteséget (MPY, Maximum Probable Yearly Aggregate Loss) a biztosítási szektorban már jóval korábban használták (ld. pl. Cummins és Freifelder, 1978). Zec (2014) ugyanakkor azt is megemlíti, hogy a VaR elvének megfelelő kockázatméréssel már a 18. és 19. században is foglalkoztak (pénzügyi) kockázatok elemzése során (pl. Condorcet, Edgeworth vagy Hicks).

Bármi volt is a forrás, kétségtelen azonban, hogy a RiskMetrics modell terjedésével a VaR rendkívül széles körben elfogadott és alkalmazott kockázatmértékké vált a pénzügyi világban. A VaR kockázatmérték interpretációja meglehetősen kézenfekvő: mennyi az a veszteség, amelynél többet adott időtávon nem szenved el a portfólió valamely kellően magas szignifikancia szint mellett. A VaR terjedésében nagy szerepet játszott az is, hogy mind a bankok, mind Európában a biztosítók felügyeletéért felelös szervezetek is validálták azt, hiszen mind a Bázeli szabályozásban, mind a Szolvencia II-ben a tőkekövetelmény számítása a VaR elve alapján történik. Ugyanakkor azt is fontos megjegyezni, hogy bár az európai biztosítókat szabályozó Szolvencia II tőkekövetelmény meghatározása is a VaR elvén alapszik, az aktuáriusok körében a VaR mindig sokkal kevésbé volt népszerü, mint a bankok és alapkezelők kockázatkezelöi körében (Ingram, 2004). Egyfelől talán az aktuáriusok tisztábban látták már a pénzügyi válság előtt is, hogy a VaR egy igencsak kétélü fegyver, másfelől nem szabad elfejtenünk azt sem, hogy a VaR-t eredetileg kereskedett termékek kockázatának mérésére vezették be (implicit módon azt feltételezi, hogy a pozíció 
adott időn belül lezárható), s ez már önmagában is megmagyarázza, miért volt kevésbé jellemző a használata biztosítók esetében.

Részben a felelősséget hárítva, de sokan okolják a VaR-t amiatt, hogy a 2007-2008-as válság során ekkora veszteségeket szenvedtek el pénzintézetek ${ }^{8}$. A VaR ugyanis hamis biztonságérzetet is adhat, hiszen arról, hogy a kimenetelek legrosszabb $\alpha$ százalékában mi történik, nem ad semmilyen információt. Ahogyan David Einhorn, egy neves alapkezelö alapítója fogalmazott, ,, a VaR olyan, mint egy légzsák, ami mindig müködik, kivéve baleset esetén” (Nocera, 2009). Valójában a VaR hibája inkább annak manipulálhatósága, azaz arra való alkalmassága, hogy az eloszlás szélébe rejtsék el vele a veszteséget - azonban pont ez mutatja, hogy a válság értelemszerüen nem egy kockázatmérték „hibája” volt, a VaR mindössze egy jó eszköznek bizonyult a kimutatott kockázatok manipulálására.

A VaR mellett, illetve ellene szóló érvekről részletes összefoglalót közölt 2009-ben a New York Times (Nocera, 2009), amely egyben azt is jól mutatja, hogy a kockázatmértékek között a VaR milyen kiemelt figyelmet kapott.

Matematikai szempontból vizsgálva a VaR alkalmazásával kapcsolatos problémák nagyon hasonlóak a szórás kapcsán felmerültekhez. Normális eloszlású változó esetén ugyanis bár a VaR jól használható, de semmilyen plusz információtartalma nincs a nála egyszerübben számítható szóráshoz képest, ekkor ugyanis a VaR a szórás konstansszorosa a választott szignifikancia szint függvényében:

$$
\operatorname{VaR}_{\alpha}(X)=\Phi^{-1}(\alpha) * D(X)-E(X)
$$

\footnotetext{
${ }^{8}$ A válság okairól szóló egyéb, legfrissebb hipotézisekről ld. pl. Bolton et al. (2017), Shin (2012), Borio és Disyatat (2011).
} 
ahol $E(X)$ a várható értéket jelöli, $\Phi^{-1}$ pedig a standard normális eloszlásfüggvény inverze. Egyéb esetben pedig az a nagy probléma a VaR-ral, hogy pont az eloszlás széléről (azaz a lehetséges legrosszabb kimenetelekről) nem mond semmit. Hasonlóan a szóráshoz, konstruálható két teljesen azonos VaR-ral jellemezhető eloszlás, melyek kockázatosság szempontjából teljesen eltérnek egymástól (pl. a maximális veszteség egyik esetben mondjuk 100-szoros a másikhoz képest).

Ha a VaR-t a koherencia szempontjából vizsgáljuk, akkor azt találjuk, hogy ez a kockázatmérték sem koherens, mivel nem tesz eleget a szubadditivitás követelményének. Így például előfordulhat, hogy két portfólió (üzletág) egyesítése után a kockázat nagyobb lesz, mint elözőleg a külön-külön számított két kockázat összege. Ez természetesen nem kívánatos. A VaR nem koherens voltát a következö egyszerü példa szemlélteti.

1.1.3. példa. Tekintsük a lenti $X_{1}, X_{2}, \in \boldsymbol{X}$ portfóliókat, és legyen a lehetséges kimenetelek halmaza $\Omega=\left\{\omega_{1}, \omega_{2}, \omega_{3}, \omega_{4}\right\}, \mathcal{M}$ jelöli $\Omega$ lehetséges részhalmazait, P pedig olyan, hogy $P=P\left(\left\{\omega_{1}\right\}\right)=P\left(\left\{\omega_{2}\right\}\right)=P\left(\left\{\omega_{3}\right\}\right)=P\left(\left\{\omega_{4}\right\}\right)=1 / 4 . \quad$ A $\quad$ kockázatot $\quad$ a $\quad$ VaR kockázatmértékkel mérjük, $\alpha=0,7$ mellett, azaz 70\%-os szignifikancia szinten. A különböző világállapotokban az egyes portfóliók értékeit, illetve az ezekböl számított kockázatot a lenti 2. táblázat tartalmazza.

2. táblázat: A VaR nem koherens

\begin{tabular}{|c|c|c|c|}
\hline$\Omega / X_{i}$ & $X_{1}$ & $X_{2}$ & $X_{1}+X_{2}$ \\
\hline \hline$\omega_{1}$ & -1 & 0 & -1 \\
\hline$\omega_{2}$ & 0 & -1 & -1 \\
\hline$\omega_{3}$ & 0 & 0 & 0 \\
\hline$\omega_{4}$ & 0 & 0 & 0 \\
\hline $\operatorname{Var}_{0,7}\left(X_{i}\right)$ & 0 & 0 & 1 \\
\hline
\end{tabular}


A fenti esetben, $\operatorname{Var}_{0,7}\left(X_{1}\right)+\operatorname{Var}_{0,7}\left(X_{2}\right)=0$, viszont $\operatorname{Var}_{0,7}\left(X_{1}+X_{2}\right)=1$, tehát $\operatorname{Var}_{0,7}\left(X_{1}+X_{2}\right)>\operatorname{Var}_{0,7}\left(X_{1}\right)+\operatorname{Var}_{0,7}\left(X_{2}\right)$, azaz nem teljesül a szubadditivitás.

\subsubsection{Az Expected Shortfall}

A koherens kockázatmértékek közül talán a legszélesebb körben alkalmazott az Expected Shortfall (Acerbi és Tasche, 2002). Az Expected Shortfall az irodalomban több különbözö néven is megtalálható, a biztosítási szakma leggyakrabban a „Conditional Tail Expectation” néven hivatkozik rá (ld. pl. Ingram, 2004), de nevezik „Tail Value at Risk-nek” is (Zec, 2014).

Az $\alpha(\alpha \in[0,1))$ szignifikancia szint mellett számított Expected Shortfall a veszteségek közül a legrosszabb $(1-\alpha) * 100$ százalék átlagát jelenti. Formálisan, legyen $X \in \mathbf{X}$ valószínűségi változó és $\alpha \in(0,1]$. Ekkor az Expected Shortfall a következőképp definiálható:

$$
E S_{\alpha}(X)=\frac{1}{1-\alpha} \int_{0}^{1-\alpha} \operatorname{VaR}_{\beta}(X) d \beta
$$

Vegyük észre, hogy amennyiben $1-\alpha$ kisebb-egyenlö, mint a legrosszabb kimenetel valószínűsége, akkor a maximális veszteséget kapjuk koherens kockázatmértékként. Az Expected Shortfall koherenciájára bizonyítást ad pl. Acerbi és Tasche (2002), vagy Kalkbrener (2005).

Míg tehát a VaR arra a kérdésre ad választ, hogy melyik az a veszteségszint, amelynél adott valószínűséggel nem szenvedünk el többet - de semmit nem mond arról, hogy pont ezen legrosszabb kimenetelek esetén mire kell számítanunk -, az Expected Shortfall azt mutatja meg, hogy a legrosszabb kimenetelek bekövetkezése esetén várhatóan mennyit veszítünk. Az Expected Shortfall számos kedvezö gyakorlati tulajdonsággal rendelkezik (nem manipulálható, könnyen interpretálható), ugyanakkor a matematikai tulajdonságok terén is 
jól teljesít, hiszen a VaR-ral ellentétben koherens (bővebben ld. Acerbi és Tasche, 2002, illetve Tasche, 2002). Nem véletlen, hogy az USA-ban és Kanadában a biztosítók a tőkekövetelményüket az Expected Shortfall mértékkel kell, hogy számszerüsítsék (Ingram, 2004).

Az Expected Shortfall bevezetése körüli vitában komoly vihart kavart, hogy az nem felel meg az elicitabilitás követelményének, ami miatt sokan azt hitték, hogy teljesítménye egyáltalán nem is visszamérhető (ld. pl. Acerbi és Székely, 2017). Az Expected Shortfall csak e kérdésnek a tisztázását követően kerülhetett be a szabályozásba.

\subsubsection{Feltételes VaR („Conditional Value at Risk”)}

Az Expected Shortfall mellett röviden kitérek még egy koncepciójában igen hasonló kockázatmértékre, a feltételes VaR-ra is. A teljesség kedvéért megjegyzendő, hogy még a szakirodalomban sem egységes a névhasználat: az Expected Shortfall, a feltételes VaR, a Conditional Tail Expectation és a Tail VaR fogalmak használata nem egységes.

A feltételes VaR azt mutatja meg, hogy mekkora a várható veszteség azokban az esetekben, amikor a veszteségünk meghaladja a VaR értékét, formálisan:

$$
\operatorname{CVaR}_{\alpha}(X)=-E\left(X \mid X \leq-\operatorname{VaR}_{\alpha}(X)\right)
$$

A feltételes VaR folytonos esetben megegyezik az Expected Shortfallal (részben ez magyarázza a nem konzisztens névhasználatot), diszkrét esetben azonban nem feltétlenül. A két kockázatmérték közül csak az Expected Shortfall koherens, a feltételes VaR nem az, így a továbbiakban a CVaR-t nem, csak az ES-t fogom használni. A két kockázatmérték közötti eltérést az alábbi példán mutatom be.

1.1.4. példa. Tekintsük a lenti $X \in X$ portfóliót, és legyen a lehetséges kimenetelek halmaza $\Omega=\left\{\omega_{1}, \omega_{2}, \omega_{3}, \omega_{4}\right\}, \quad \mathrm{P}$ pedig olyan, hogy $P=P\left(\left\{\omega_{1}\right\}\right)=P\left(\left\{\omega_{2}\right\}\right)=P\left(\left\{\omega_{3}\right\}\right)=$ $P\left(\left\{\omega_{4}\right\}\right)=1 / 4$. Számítsuk ki a portfólió kockázatát az Expected Shortfall, illetve a 
feltételes VaR kockázatmértékkel is, $\alpha=0,7$ esetén. A különböző világállapotokban az egyes portfóliók értékeit, illetve az ezekből számított kockázatot a lenti tartalmazza.

3. táblázat: Az Expected Shortfall és a feltételes VaR eltérése-diszkrét eset

\begin{tabular}{|c|c|}
\hline$\Omega / X$ & $X$ \\
\hline$\omega_{1}$ & -4 \\
\hline$\omega_{2}$ & -3 \\
\hline$\omega_{3}$ & -2 \\
\hline$\omega_{4}$ & -1 \\
\hline$E S_{0,7}(X)$ & 3,8333 \\
\hline \hline $\operatorname{CVaR}_{0,7}(X)$ & 3,5 \\
\hline
\end{tabular}

Egyszerü számítással ellenőrizhető, hogy a fenti esetben $E S_{0,7}(X)=-\frac{0,25 \cdot(-4)+0,05 \cdot(-3)}{0,3}=$ 3,8333, ugyanakkor $C V a R_{0,7}=-\frac{0,25 \cdot(-4)+0,25 \cdot(-3)}{0,5}=3,5$. Grafikusan az eltérés talán még jobban szemléltethető, melyet a következő ábra mutat. 
Az ES számítás:

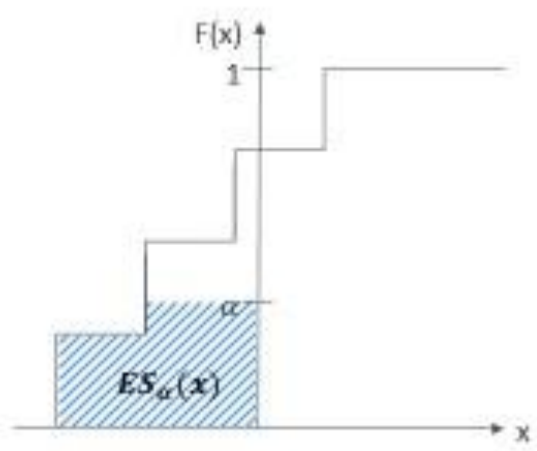

A CVaR számitása

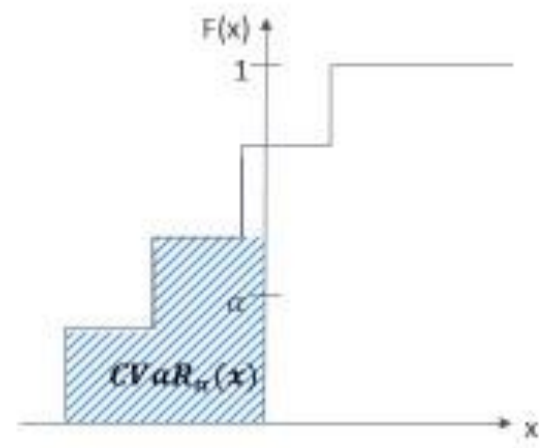

\subsection{TÖKEKÖVETELMÉNY ÉS TŐKEFOGALMAK A BIZTOSÍTÁSI SZEKTORBAN}

Az előző fejezetben a pénzügyi vállalatok által vállalt kockázatok mérésével foglalkoztam. A kockázatok mérésének egyik legfontosabb célja, hogy e vállalatok tőkekövetelményét számszerüsíteni lehessen - vagyis meghatározzuk, mennyi forrást kell a vállalat tulajdonosainak rendelkezésre bocsátania annak érdekében, hogy az nagy biztonsággal ne váljon fizetésképtelenné.

Tőke alatt a továbbiakban a nem várt veszteségek fedezésére szolgáló, elsősorban az ügyfelek követeléseit biztosító tartalékot tekintem. Bár a kérdés, hogy mit is tekintünk egy vállalat tőkéjének, triviálisnak tűnhet, valójában rengeteg tőkefogalommal találkozunk akár az irodalomban, akár egy-egy bank vagy biztosító mérlegét tanulmányozva (szabályozói tőke, gazdasági tőke, különböző számviteli kategóriák). A lehetséges tőkefogalmakat vizsgálva első lépésben (ahogyan Farr et al., 2008 is javasolja), meg kell különböztetnünk az elvárt (valamilyen kockázatmérési módszerrel számszerüsített, elméleti) tởkeigény és a 
rendelkezésre álló tőke fogalmát. A rendelkezésre álló tőke egy számviteli kategória, amely egyszerüen a biztosító mérlegéből kiolvasható, némi egyszerüsítéssel élve az eszközök és kötelezettségek különbségeként. Albrecht (2006) a szintén beszédes „fizikai tőke” elnevezést használja. Az elvárt tőkét is célszerủ még legalább két osztályra bontani, ahogyan azt az Aktuáriusok Szövetsége által jegyzett „Specialty Guide on Economic Capital” c. kiadvány is javasolja (Mueller et al., 2004): szabályozói tökekövetelményre és gazdasági tőkeszükségletre. Szolvens pénzügyi vállalkozások esetében a rendelkezésre álló tőke szintje meghaladja mind a szabályozói tőkekövetelmény, mind a gazdasági tőkeszükséglet értékét, míg az utóbbi kettő szintje között nincs általánosan érvényes reláció.

\subsubsection{SZABÁLYOZÓI TŐKEKÖVETELMÉNY - SZOLVENCIA II}

Szabályozói tőkeszükséglet alatt a szabályozó által előírt kötelező minimum tőkekövetelményt értjük - az Európai Gazdasági Térségben ez a Szolvencia II irányelv (a továbbiakban Szolvencia II, vagy az Irányelv) szerinti tőkekövetelményt jelenti. Az alábbiakban röviden bemutatom a 2016 januárjában bevezetett, így az európai biztosítási szektor szereplői számára meglehetősen fontos aktualitást jelentő irányelv követelményeit.

A Szolvencia II a bankokra vonatkozó Bázel II-vel (illetve Bázel III-mal) teljesen analóg módon három pillérre épül. Az első pillér tartalmazza a kvantitatív elöírásokat: a kötelező tőkeszámítás módszertanát valamint az egyes mérlegtételek értékelésének szabályait. A tőkekövetelmény számítása során a biztosítók a standard módszer, részleges vagy teljes belső modell alkalmazása mellett dönthetnek, utóbbi kettő előzetes felügyeleti engedélyhez kötött. Maga a Szolvencia II tőkekövetelmény (SCR) akár belső modellel, akár a standard módszerrel kerül kiszámításra, 99,5\%-os szignifikancia szint és egy éves időhorizont mellett számított kockázatott értéknek (VaR) felel meg (azaz az a veszteségszint, amelynél nagyobb várhatóan csak 200 évente egyszer következik be). Az SCR mellett az irányelv még egy 
mutató: a minimális tőkeszükséglet (MCR) számítását is előírja. Az MCR 85\%-os szignifikancia szint mellett számított kockázatott értéknek felel meg, és azonnali felügyeleti intézkedést von maga után, ha az intézmény tőkéje ez alá a szint alá csökken (természetesen a felügyelet már az SCR szint átlépésekor beavatkozik, de fokozatosan, eleinte kevésbé kemény intézkedésekkel).

A VaR koncepciójának megfeleltethető tőkekövetelmény számítás jelentős előrelépés a Szolvencia I jóval kevésbé kockázatérzékeny, arányszám alapú tőkeszámítási gyakorlatához képest. Szintén fontos különbség, hogy az új irányelv piaci árakon alapuló értékelést ír elő a korábbi, könyv szerinti (az adott országban alkalmazott értékelési standardok szerinti) értékelés helyett. A régi és az új direktíva megközelítése közötti különbséget az alábbi ábra szemlélteti.

2. ábra: A szabályozói tökekövetelmény a Szolvencia I és II irányelvek szerint

\section{Szolvencia I}
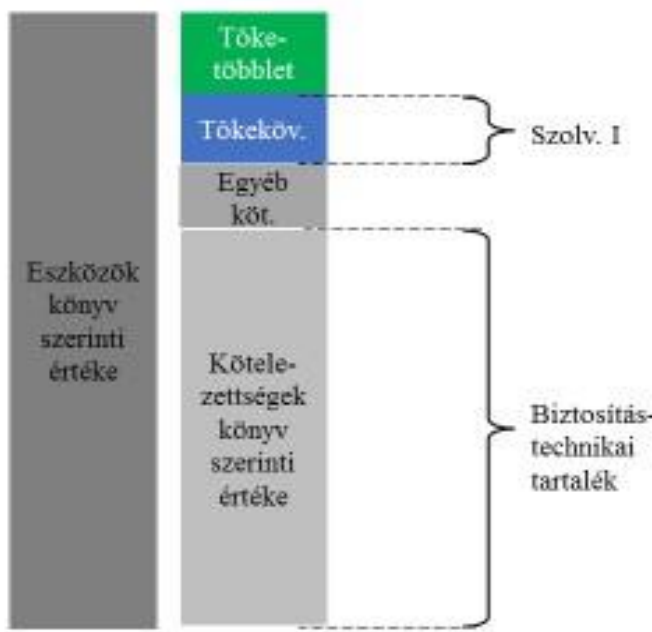

\section{Szolvencia II}

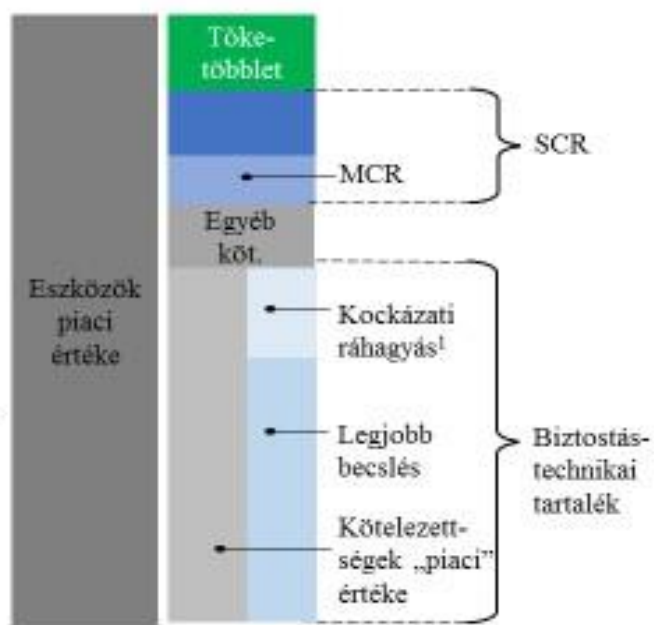

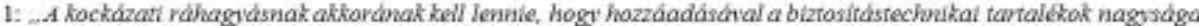
megegyezzen azzal az értékhel, amelyre egy biztositónak̀ vagy viszontbizzositonak a biztositási és viszontbiztositósi kobtelezertségek ävaillaiàsähoz és teljesitéséhez szuksège lenne. "(SII, 77, cikk)

A második pillér az első pillér kvantitatív követelményeit kvalitatív jellegü előírásokkal egészíti ki. A biztosítók felügyeletének eljárásrendje mellett a második pillér tartalmazza a 
társaság belső irányítási és kockázatkezelési rendszerére, valamint a belső tőkeszámításra vonatkozó szabályokat. A kockázatkezelési rendszerre vonatkozó előírások értelmében a kockázatkezelési funkció a vállalat szerves részét kell, hogy képezze ${ }^{9}$. A vállalat napi müködésébe jól beágyazott kockázatkezelési rendszer korábban is a biztosítói legjobb gyakorlatok részét képezte (ERM, enterprise risk management), azonban csak a Szolvencia II-vel vált szabályozói elvárássá is. Az ERM rendszerekröl az 1. mellékletben adok rövid áttekintést. A kockázatkezelésre vonatkozó követelmények között az irányelv a releváns kockázatok azonosítására, mérésére és kezelésére megfelelő szervezet, folyamatok (politikák, eljárásrendek) és jelentési (riportolási) rend meglétét is elvárja.

A második pillér fontos eleme a Saját Kockázat és Szavatolótőke Értékelés (a továbbiakban ORSA, Own Risk and Solvency Assessment) folyamat, amely a biztosítóknál a banki ICAAP ${ }^{10}$ megfelelője. Az ORSA folyamat foglalja magába a belső (gazdasági) tőkeszükséglet számítást (melyet bár a szabályozó ellenőriz, de elvi szinten nem jár tényleges tőkeképzési kötelezettséggel), így a biztosítói gyakorlatnak korábban is fontos részét képező gazdasági tőkeszükséglet számítás a Szolvencia II bevezetésével szintén a felügyelet ellenőrzése alá kerül. A tőkemodellezés mellett a második pillér nagy hangsúlyt helyez a kapcsolódó szervezeti keretre és folyamatokra is: az üzleti döntésekkel integrált kockázatkezelési folyamatok meglétét is az ORSA biztosítja. ${ }^{11}$ Ahogyan majd a 3. részben látni fogjuk, ezen a ponton kapcsolódik a tőkeallokáció a tőkekövetelmény számításhoz és a szabályozói elvárásokhoz, hiszen a tőkeallokáció a belső tőkeszükséglet számítás üzleti és stratégiai döntések során történő felhasználásának egyik legfontosabb eszköze (a

\footnotetext{
${ }^{9}$ A direktíva 44. cikkelye szerint „, A kockázatkezelési rendszernek hatékonynak kell lennie, és a rendszert a biztositó vagy viszontbiztositó szervezeti felépitésébe és döntéshozatali folyamataiba kell integrálni”.

${ }^{10}$ Belső tőkemegfelelési értékelési folyamat (Internal Capital Adequacy Assessment Process).

11 A direktíva 45. (4) cikkelye szerint „A saját kockázat- és szavatolótőke-megfelelésértékelés az üzleti stratégia szerves része, amelyet a vállalkozás stratégiai döntései során folyamatosan alkalmazni kell.”.
} 
teljesítményértékelésen keresztül például az üzletág hozamát köti össze a kockázatával, vagyis a rá allokált tőkével).

Az irányelv harmadik pillére a közzétételi követelményeket tartalmazza.

\subsubsection{GAZDASÁGI TŐKESZÜKSÉGLET}

Gazdasági tőkeszükséglet alatt a társaság belső kockázatértékelése alapján számított tőkeigényt értjük. A gazdasági tőkeszükséglet számításának célja, hogy a lehető legpontosabban kerüljenek felmérésre és számszerüsítésre a biztosító tevékenysége során felmerülő kockázatok. A gazdasági tőkeszükséglet modellezése a biztosító belső kockázatértékelési folyamatának része, eredményét a biztosító vállalatirányítási rendszerében használja fel.

Sandström (2011, p68) a következő definíciót adja: ,, a gazdasági tőke[szükséglet] az a tőke mennyiség, amely a vállalat számára szükséges ahhoz, hogy az aktuálisan fennálló szerzödéseiböl eredö kötelezettségeinek nagy biztonsággal eleget tegyen meghatározott idö alatt, s amely lehetôvé teszi aktuális hitelminősitésének szinten tartását”.

Mueller et al. (2004) szerint a gazdasági tőkeszükségletre ugyan számos definíció adható, de mindegyikben közös, hogy az események kedvezötlen alakulása esetén felmerülő, adott idő alatt felmerülő veszteségek fedezésére szükséges tőke mennyiségét jelenti, előre definiált kockázattürési határ (konfidencia szint) mellett.

Számunkra ez a tőkefogalom mind közül a legfontosabb, hiszen ez az, ami valójában a biztosító (vagy bármely más entitás, portfólió) kockázatának egy kiválasztott kockázatmértékkel történő számszerüsítésének eredményéül áll elő.

Összevetve a gazdasági tőkeszükséglet és a szabályozói tőkekövetelmény fogalmát azt láthatjuk, hogy gazdasági tőkének tekinthető a Szolvencia II irányelv második pillére alatt 
számított belső tőkeigény is. A gazdasági és a(z első pillér alatt számított) szabályozói tőkekövetelmény - a szabályozói módszer standardizáltabb, kevésbé kockázat-érzékeny voltából adódóan - korábban jelentős mértékben eltérhetett egymástól, mára azonban ez a differencia a Szolvencia II kockázat-érzékenyebb első pilléres tőkekövetelmény számítási módszertanának köszönhetően jelentősen csökkent (vagy akár el is tünt, amennyiben a biztosító az első pillér alatt belső modell használatát választja). Az irányelv a standard módszer szerinti tőkekövetelményt is 99,5\%-os szignifikancia szint mellett számított VaRral ekvivalens kockázati mérőszámként definiálja, így a szabályozói tőke is egyre inkább „gazdasági tőke jellegűvé” válik.

\subsection{KÖLTSÉGJÁTÉKOK - KOOPERATÍV JÁTÉKELMÉLETI KITÉRŐ}

A disszertáció jelen, 1. részében a célom a kockázat méréséhez és a tőkekövetelmény számításához szükséges fogalmak megadásával a továbbiakban használandó fogalmi keretrendszer definiálása. Ennek szellemében, mielőtt rátérnék a tőkeallokáció kérdésének vizsgálatára, szükségesnek tartom röviden a témához szintén szervesen kapcsolódó, a kooperatív játékelméletben gyakran vizsgált költségjátékokhoz kapcsolódó alapfogalmakat is megadni. A következő rövid áttekintés föként Peters (2008) könyvére és Solymosi (2007) jegyzetére épül.

Kooperatív játékok olyan játékokat értünk, ahol a játékosok között létrejöhetnek kötelező érvényü egyezségek - szemben a nem-kooperatív játékokkal, ahol ez értelemszerűen nem lehetséges. Más megközelítésben talán egyértelműbb határvonal húzható a két típusú játék között azzal a megkülönböztetéssel, hogy míg a nem-kooperatív játékokban a játékosok explicit stratégiákkal rendelkeznek, a kooperatív játékokban az egyes szereplőket és koalíciókat az általuk elérhető kifizetéssel tudjuk jellemezni (Peters, 2008). 
A kooperatív játékokon belül két további nagy csoportot az átváltható (átruházható) hasznossággal rendelkező (transferable utility, azaz TU játékok), illetve a nem átváltható (nem átruházható) hasznossággal rendelkező játékok (nontransferable utility, NTU játékok). Előbbi esetében az egyes szereplők preferenciái összevethetőek - tulajdonképpen valamilyen egységes mértékegységben, pl. pénzben mérhetőek -, míg utóbbi esetben az összehasonlítás nem feltétlenül lehetséges. A továbbiakban a disszertációban csak a kooperatív játékokra, azok közül pedig kizárólag az átváltható hasznossággal rendelkezőkre koncentrálok.

1.3.1. definíció.(Peters, 2008). Egy átváltható hasznossággal rendelkezö, azaz TUjátékot az $(N, v)$ párral tudunk leirni, ahol $N=\{1,2 \ldots n\}, n \in \mathbb{N}$ a játékosok halmaza, v pedig egy olyan függvény, amely a lehetséges $S \subseteq N$ koalíciókhoz rendeli hozzá azok értékét, egy valós számot, v(S)-t. Az N koalíciót nagykoaliciónak nevezzük, a v függvényt pedig karakterisztikus függvénynek. A kifizetés elosztása az S koalición értelmezve $\left(x_{i}\right)_{i \in S}$ egy valós számokból álló vektor. Jelölje továbbá $2^{N}$ a lehetséges koalíciók halmazát, azaz v: $2^{N} \rightarrow \mathbb{R}$ függvény, amelyre $v(\varnothing)=0$.

A TU játékokat további kategóriákra bonthatjuk aszerint, hogy eredményezhet-e hasznot az egyes szereplők összefogása.

\subsection{2. definíció (Solymosi, 2007). Az (N,v) játék}

- additiv, hav $v(S)=\sum_{i \in S} v(i)$ minden $S \in 2^{N}$-re;

- szuperadditív, $v(S)+v(T) \leq v(S \cup T)$ igaz minden $S, T \in 2^{N}$-re, amelyre $S \cap$ $T=\emptyset ;$

- konstans-összegü, ha $v(S)+v(N \backslash S)=v(N)$ minden $S \in 2^{N}-r e$. 
Számunkra a fentiek közül természetesen a szuperadditív játékok érdekesek, hiszen a tőkeallokációs módszerekkel pontosan az együttmüködésből eredő diverzifikációs hasznot szeretnénk elosztani az egyes játékosok között.

Mint a bevezetőben említettem, a tőkekövetelmény költséget jelent a biztosító számára, és a kérdés ennek a költségnek a felosztása az egyes alegységek között. Emiatt érdemes lehet a játékelméletben is sokszor külön tárgyalt, de teljesen a fentiekkel analóg kategória, a költségjátékok definiálása. Egy költségjátékot egy $(N, c)$ párral jellemezhetünk, ahol $c$ a költségfüggvény, azaz $c(S)$ az $\mathrm{S}$ koalíció költségét adja meg. Természetesen egy $(N, c)$ költségjáték egy klasszikus, „nagyobb a jobb” típusú $(N, v)$ TU játékból $(N,-v)$-ként is felírható lenne, és amíg $(N, v)$ szuperadditív játék, addig ennek $(N,-v)$ költségjáték megfelelője értelemszerüen szubadditív. Amennyiben egy pénzügyi egység és annak alegységeinek kockázatát koherens kockázatmértékkel mérjük, szubadditív költségjátékot kapunk (mivel esetünkben a költségfüggvény a kockázatmérték, és a koherens kockázatmértékek szubadditívak). A költségjátékok egy speciális típusa a Denault (2001) által definiált kockázatallokációs játék (,risk allocation game”), melyben a létrejövő koalíciók kockázatának elosztását vizsgáljuk az egyes játékosok között.

1.3.3 definició. Jelölje az $(N, c)$ költségjáték kimenetelét $x(N)$, amely ezúttal tehát az egyes játékosokra eső kockázatokat (költségeket) tartalmazó vektor. Egy elosztásra azt mondjuk, hogy hatékony, ha $\sum_{i \in N} x_{i}=c(N)$. Egy elosztás akkor egyénileg elfogadható (individuálisan racionális), ha $x_{i} \leq c(i)$ minden $i \in N$-re. Illetve akkor magbeli (esetleg: csoportosan elfogadható), ha $\sum_{i \in S} x_{i} \leq c(S)$ minden $S \in 2^{N}$-re.

A mag nem-ürességét Bondareva (1963) és Shapley (1967) tétele biztosítja, amelynek megértéséhez még egy fogalom, a kiegyensúlyozottság definiálására van szükségünk. 
1.3.4 definició. Egy játék kiegyensúlyozott, amennyiben $\sum_{S \in 2^{N}} \lambda_{S} c(S) \geq c(N)$, ahol $\lambda_{S} \in$ $[0,1]$ olyan, hogy $\sum_{S \in 2^{N}} \lambda_{S} 1_{S}=1_{N}$, ahol $1_{S} \in R^{n}$ az $S$ koalíció karakterisztikus vektora (azaz egy eleme akkor egyes, ha az adott játékos a koalíció tagja, egyéb esetben nulla).

1.3.5 tétel (Bondareva-Shapley). Egy TU-játék magja pontosan akkor nem üres, ha a játék kiegyensúlyozott.

A kiegyensúlyozott játék definícióját tovább szűkítve kapjuk a teljesen kiegyensúlyozott játékok osztályát. Egy játék akkor teljesen kiegyensúlyozott, ha minden részjátéka is kiegyensúlyozott. Egy adott $(N, c)$ játék és $S \in 2^{N}$ esetén az $\left(S, c^{S}\right)$ részjátékot a $c$ függvény S-re való leszükítésével kapjuk. Csóka et al. (2009) megmutatta, hogy koherens kockázatmérték alkalmazása mellett a kockázatallokációs játékok osztálya egybeesik a teljesen kiegyensúlyozott játékok osztályával, így értelemszerűen a kockázatallokációs játékok magja, sőt, a kockázatallokációs játékok minden részjátékának magja sem üres; továbbá tetszőleges teljesen kiegyensúlyozott játék előállítható kockázatallokációs játékkal. 


\section{RÉSZ: A TŐKEALLOKÁCIÓ ELMÉLETI MODELLJE: AZ ALKALMAZHATÓ}

\section{MÓDSZEREK ÖSSZEHASONLÍTÁSA ${ }^{12}$}

Amennyiben egy pénzügyi egység (egy bank, biztosító, egy ország pénzügyi rendszere stb.) több alegységből áll (üzletágak, leányvállalatok stb.), akkor a teljes kockázatot valamilyen tőkeallokációs módszer segítségével tudjuk szétosztani az alegységek között. A tanulmány jelen részében elöbb formálisan is felírjuk a tőkeallokációs problémát, majd az allokáció elméleti, módszertani kérdéseivel foglalkozunk.

A következő hét, az irodalomban gyakran előforduló, illetve a gyakorlatban alkalmazott módszert vizsgáljuk: egyéni kockázattal arányos módszer (Hamlen et al., 1977); béta módszer (ld. pl. Homburg és Scherpereel, 2008); növekményi módszer (ld. pl. Jorion, 2007); költségrés módszer (Tijs és Driessen, 1986); marginális kockázati hozzájárulás - mint iránymenti derivált (Cherny és Orlov, 2011) és mint parciális derivált, más néven Euler módszer (1d. pl. Denault, 2001, vagy Buch és Dorfleitner, 2008); a Shapley-módszer (Shapley, 1953) és a nukleolusz módszer (Schmeidler, 1969). A módszerek vizsgálata során az egyes követelmények teljesítését csak az adott módszer értelmezési tartományán várjuk el: vannak módszerek, melyek nem mindig definiáltak, azaz nem teljesítik az első vizsgált tulajdonságot, a teljes értelmezési tartományon való definiáltságot („,Full Domain”, a továbbiakban mindig értelmezett vagy MÉ). Ezen felül további kilenc tulajdonság teljesítését vizsgáljuk, melyek két csoportba sorolhatóak. Az első csoport tulajdonságai az egyes alegységekből álló halmazok (koalíciók) kockázataival foglalkozó kooperatív játékelmélethez kapcsolódnak: magbeliség; diverzifikáció; erős monotonitás; hatékonyság; egyenlöen kezelés. A második csoport tulajdonságai közvetlenül a portfólión definiáltak, a

\footnotetext{
${ }^{12}$ Jelen rész minimális módosításokkal Balog et al. (2017) cikkén alapul, a társszerzők, Bátyi Tamás László, Csóka Péter és Pintér Miklós hozzájárulásával.
} 
kockázatmérték használata nélkül: az ösztönzés, a kockázatmentes allokáció, a kovariancia és a dekompozíció invariancia.

A tanulmány jelen részében végig véges valószínűségi mezővel dolgozunk, ahol a véletlen változók vektorok, és a pozitív kimeneteleket nyereségként értelmezzük. A kockázat mérésére csak koherens kockázatmértékeket (Artzner et al., 1999) alkalmazunk, melyekről az 1.1.2. fejezetben található bővebb ismertetés. A koherens kockázatmértékek axiómái közül az elemzés szempontjából kiemelten fontos a szubadditivitás, amely a diverzifikációhoz kapcsolódik: az alegységek kockázatainak összege legalább ugyanannyi, mint a teljes portfólió kockázata. E diverzifikációs hatás eredményeképp adódó kockázatcsökkenés az, amelyet igazságosan szét kell osztani az alegységek között a tőkeallokáció során.

A Shapley érték (Shapley, 1953) a kooperatív játékelmélet jól ismert módszere nyereségek és költségek allokálására. A Shapley érték Young-féle axiomatizálását (Young, 1985) általánosítva Csóka és Pintér (2016) egy lehetetlenségi tételt bizonyított be, amely a tulajdonságok mindkét csoportjához kapcsolódik: koherens kockázatmérték használata mellett nincs olyan tőkeallokációs módszer, amely a fent említett tulajdonságok közül egyszerre teljesítene hármat: a mindig értelmezettség ${ }^{13}$, a magbeliség és az ösztönzés feltételét (az egyes tulajdonságokat majd a 2.1 fejezetben definiáljuk).

A magbeliség (a tulajdonságra „No undercut” néven hivatkozik Denault, 2001, illetve Buch és Dorfleitner, 2008) biztosítja, hogy a teljes portfólió olyan módon kerül szétosztásra, melynek eredményeképp egy alegység (koalíció) sem visel több kockázatot, mint amennyi az ő önálló kockázata lenne, hiszen egyéb esetben az adott alegységek (vagy koalíció) nem fogadnák el az adott elosztást. Denault (2001), Csóka et al. (2009), valamint illikvid

\footnotetext{
${ }^{13}$ A tulajdonságot Csóka és Pintér (2016) implicit módon feltételezi.
} 
portfóliók esetében Csóka és Herings (2014) megmutatta, hogy magbeli elosztás mindig létezik. Csóka és Pintér (2016) pedig bebizonyította, hogy a magbeliséget úgy is definiálhatjuk, hogy minden koalícióra legalább annyi kockázatot kell allokálni, amennyivel a koalíció megnöveli a rajta kívül álló alegységek kockázatát azokhoz csatlakozva. Hougard és Smilgins (2016) értelmezésében a magallokáció követelménye biztosítja, hogy egyik alegységet sem kap támogatást egy másik egység kárára.

Az ösztönzés tulajdonságot Csóka és Pintér (2016, 3.8 példa) vezeti be implicit módon, és azt várja el, hogy ha egy adott portfólió értéke (profitja) úgy változik, hogy egyik világállapotban sem növekszik, akkor a rá allokált töke nem csökkenhet, hiszen ez esetben a portfóliót pont kockázatának növelésére ösztönöznénk.

Minden módszer és tulajdonság esetében bizonyítással vagy ellenpéldával mutatjuk meg, hogy az adott módszer teljesíti-e a szóban forgó tulajdonságot. Az analitikus eredményeket a 19. táblázat összegzi, amely hasznos támpontként szolgálhat a gyakorlati alkalmazóknak a módszerek közötti választásban. Továbbá segítséget nyújthat abban is, hogy egy adott módszer alkalmazása esetén milyen esetleges problémára kell felkészülni az alkalmazás során. Természetesen nem lehetséges minden, az irodalomban előforduló módszert tárgyalni, de úgy gondoljuk, ez a hét módszer megfelelő támpontot ad a döntéshozóknak.

Ha egy módszer egy adott tulajdonságot nem teljesít, az még nem biztos, hogy problémát jelent az alkalmazás során, ha a tulajdonság megsértése csak bizonyos elméletileg lehetséges, ám a gyakorlatban nem releváns esetekben fordul elő. Mivel egyrészt a teljes értelmezési tartományon való definiáltság, a magbeliség és az ösztönzés követelményeinek nem lehetséges egyszerre megfelelni, másrészt viszont mindig el lehet osztani úgy a kockázatot, hogy egyik koalícióra sem allokálunk több tőkét, mint amennyi az ő önálló tőkekövetelménye lenne, a magallokáció követelményére fókuszálunk. Hogy tisztábban lássunk, megvizsgáljuk, hogy legfeljebb kilenc alegységet tartalmazó portfóliók esetén, 
véletlenszerüen generált tőkeallokációs szituációkban ${ }^{14}$ milyen arányban eredményez magbeli elosztást az egyéni kockázattal arányos, a béta, a növekményi, a költségrés és a Shapley-módszer. Mivel a nukleolusz módszer, illetve a fenti szimulált környezetben a marginális kockázati hozzájárulás mindkét típusa mindig eleget tesz a magbeliség követelményének, ezek nem képezték tárgyát a szimulációs vizsgálatnak. A maradék öt módszerre három-kilenc alegység mellett 24-24 esetet szimulálunk: kétféle portfólió méret (azonos nagyságúak vagy sem), a hozamok szórásának különböző mértéke (kicsi vagy nagy), a hozamok többféle eloszlása (normális, vagy vastagszélü, ld. pl. Cont, 2001) és három szignifikancia szint (90\%, 95\% és 99,9\%, ez utóbbi esetünkben a maximális veszteség) mellett. Megmutatjuk, hogy legjobban a költségrés módszer teljesít, jellemzően 90\% feletti arányban ad magbeli elosztást, bár ez egyes esetekben akár 30\%-ig is lemehet. Általában a magbeli elosztások aránya nagyban függ a szimuláció paramétereitől, de minden esetben csökken az alegységek számának csökkenésével.

A tanulmány jelen, módszertani részének felépítése a következő. A következő fejezetben definiáljuk a vizsgált tíz tulajdonságot. A 2.2. fejezetben adjuk meg a hét vizsgált tőkeallokációs módszert és megmutatjuk, hogy azok mely tulajdonságokat teljesítik az értelmezési tartományukon. Az 2.3. fejezetben és a kapcsolódó mellékletekben mutatjuk be a szimuláció eredményeit. A 2.4. fejezetben összefoglaljuk a vizsgálat eredményeit.

\subsection{A TŐKEALLOKÁCIÓS PROBLÉMA, JELÖLÉSEK}

Vizsgálatunk tárgya a következő probléma. Egy pénzügyi egység (pl. egy biztosító, vagy egy bank) véges számú alegységből (pl. üzletágakból) tevődik össze. Az alegységek

\footnotetext{
${ }^{14}$ Egy-egy tőkeallokációs szituáció összetevői az alábbiak: az alegységek, a portfólióik, és egy koherens kockázatmérték.
} 
halmazát jelölje $N=\{1,2 \ldots n\}$. Az egyes alegységek által elérhető profitot (veszteséget) az 1.1.1 fejezetben alkalmazott felírásnak megfelelöen jelölje $X_{i} \in \mathbf{X}, i \in N$, ahol $\mathbf{X}$ továbbra is a $(\Omega, \mathcal{M}, P)$ diszkrét valószínüségi mezőn értelmezett valószínűségi változók halmaza, amely reprezentálható egy realizációs vektorral, amely az alegység hozamát adja meg az egyes lehetséges világállapotokban. Szintén vizsgáljuk majd az alegységekből álló halmazokat. Egy $S \subseteq N$ koalíciót az $X_{S}=\sum_{i \in S} X_{i} \in \mathbf{X}$ valószínűségi változó reprezentál, ahol az üres halmaz értéke 0 .

A $\rho: \mathbf{X} \rightarrow \mathbb{R}$ függvényt a korábbiaknak megfelelően kockázatmértéknek nevezzük, amely megadja az egyes alegységek (és ezekből álló koalíciók) kockázatát. Az így értelmezett kockázatot tekinthetjük annak az összegnek - töke -, amelyet a portfólióhoz adva az elfogadhatóvá válik. A továbbiakban csak koherens kockázatmértékekkel foglalkozunk, melyek definícióját az 1.1.2. fejezetben adtuk meg.

A példákban és a szimulációk során az Expected Shortfall (Acerbi és Tasche, 2002) kockázatmértéket fogjuk alkalmazni, $\alpha \in[0,1)$ szignifikancia mellett (melyre a továbbiakban az egyszerüség kedvéért $\alpha$-Expected Shortfallként hivatkozunk, $\alpha$-t százalékban megadva), amely a veszteségek közül a legrosszabb $100-\alpha$ százalék átlagát jelenti, és amely egy koherens kockázatmérték (ld. az 1.1.3.3. fejezetet).

A tőkeallokációs szituációt jelöljük a következőképp: $X_{N}^{\rho}=\left\{N,\left\{X_{i}\right\}_{i \in N}, \rho\right\}$, ahol $N$ az alegységek halmaza, $\left\{X_{i}\right\}_{i \in N}$ az egyes alegységek hozamait leíró valószínüségi változók halmaza, $\rho$ pedig egy koherens kockázatmérték. Az $N$ melletti tőkeallokációs szituációk osztályát jelölje $R C A S_{N}$ (,risk capital allocation situation”).

2.1.1. példa. Tekintsük az $X_{N}^{\rho} \in R C A S_{N}$ tökeallokációs szituációt, ahol a lehetséges kimenetelek halmaza $\Omega=\left\{\omega_{1}, \omega_{2}, \omega_{3}, \omega_{4}\right\}, \quad P$ pedig olyan, hogy $P=P\left(\left\{\omega_{1}\right\}\right)=$ $P\left(\left\{\omega_{2}\right\}\right)=P\left(\left\{\omega_{3}\right\}\right)=P\left(\left\{\omega_{4}\right\}\right)=1 / 4$. Három alegységünk van, $N=\{1,2,3\}$, és az 
alkalmazott $\rho$ kockázatmérték a 75\%-Expected Shortfall, ami jelen esetben (és minden $\alpha \in$ $[0,75,1)$ számra) megegyezik a maximális veszteséggel. Az $S \subseteq N$ halmazokra $X_{S}$ értékeit, illetve ezek kockázatát a 4. táblázat tartalmazza. (Szintén ezt a példát fogjuk használni a béta módszer (2.2.2. fejezet), a növekményi módszer (2.2.3. fejezet) és a marginális kockázati hozzájárulás (2.2.5. fejezet) tárgyalásakor, illetve az egyes módszerekkel történö allokáció eredményeit összehasonlitandó a 2.2.8 fejezetben.)

4. táblázat: $A z X_{N}^{\rho}$ tökeallokációs szituáció

\begin{tabular}{|c|c|c|c|c|c|c|c|}
\hline$\Omega / X_{S}$ & $X_{1}$ & $X_{2}$ & $X_{3}$ & $X_{\{1,2\}}$ & $X_{\{1,3\}}$ & $X_{\{2,3\}}$ & $X_{\{1,2,3\}}$ \\
\hline$\omega_{1}$ & -10 & -10 & 0 & -20 & -10 & -10 & -20 \\
\hline$\omega_{2}$ & -3 & -4 & -100 & -7 & -103 & -104 & -107 \\
\hline$\omega_{3}$ & -6 & 0 & -99 & -6 & -105 & -99 & -105 \\
\hline$\omega_{4}$ & 0 & -6 & -99 & -6 & -99 & -105 & -105 \\
\hline$\rho\left\{X_{S}\right\}$ & 10 & 10 & 100 & 20 & 105 & 105 & 107 \\
\hline
\end{tabular}

Vegyük észre, hogy jelentős diverzifikációs hatás adódik a három alegység koalíciójából:

$$
\rho\left(X_{N}\right)=107<120=\sum_{i \in N} \rho\left(X_{i}\right) .
$$

Mint a fenti példában, két kérdés merül fel a tőkeallokáció kapcsán: Hogyan osszuk szét a diverzifikációból eredő megtakarítást az alegységek között? Milyen tulajdonságokkal rendelkezzen az alkalmazott allokációs módszer?

A $D_{\varphi} \subseteq R C A S_{N}$ tartományon értelmezett $\varphi: R C A S_{N} \rightarrow \mathbb{R}^{N}$ függvényt tőkeallokációs módszernek nevezzük. A tőkeallokációs módszer meghatározza, hogy az egyes szituációkban mekkora tőkét allokáljunk az egyes alegységekre. A tőkeallokációs módszerek alábbi tíz lehetséges tulajdonságát vizsgáljuk. Az egyes tulajdonságok 
definícióját, illetve értelmezését az alábbiakban adjuk meg. A lent vizsgált tíz tulajdonsággal gyakorlatilag az irodalomban vizsgált összes, módszertani szempontból érdekes tulajdonságot lefedjük ${ }^{15}$. (A gyakorlati alkalmazás során természetesen ezen felüli, „puhább” kritériumok is felmerülhetnek: pl. mennyire szemléletes, könnyen érthető a módszer, a számítás bonyolultsága, illetve adott szituációban való nemnegativitás ${ }^{16}$, ld. majd

\section{a 3.4.2 fejezetben.)}

\subsection{2. definíció. Egy tőkeallokációs módszer}

- Mindig értelmezett (MÉ), ha $D_{\varphi}=R C A S_{N}$;

- Diverzifikáló (Div), ha minden $X_{N}^{\rho} \in D_{\varphi}$ tőkeallokációs szituációra $\sum_{i \in N} \varphi_{i}\left(X_{N}^{\rho}\right)=$ $\rho\left(X_{N}\right)$ (azaz hatékony, ld. lejjebb) és minden $\mathrm{i} \in \mathrm{N}-r e \varphi_{i}\left(X_{N}^{\rho}\right) \leq \rho\left(X_{i}\right)$ (azaz individuálisan racionális);

- $\operatorname{Magbeli}(\boldsymbol{M})$, ha minden $X_{N}^{\rho} \in D_{\varphi}$ tőkeallokációs szituációra $\sum_{i \in N} \varphi_{i}\left(X_{N}^{\rho}\right)=\rho\left(X_{N}\right)$ (azaz hatékony, ld. lejjebb) és minden $S \subseteq N$-re $\sum_{i \in S} \varphi_{i}\left(X_{N}^{\rho}\right) \leq \rho\left(X_{\mathrm{S}}\right)$;

- Erösen monoton (EM), ha minden $X_{N}^{\rho}, Y_{N}^{\rho} \in D_{\varphi}$ tőkeallokációs szituációra és $i \in \mathrm{N}$ alegységre, amennyiben $\rho\left(\mathrm{X}_{\mathrm{S} \cup\{\mathrm{i}\}}\right)-\rho\left(\mathrm{X}_{\mathrm{S}}\right) \leq \rho\left(\mathrm{Y}_{\mathrm{S} \cup\{\mathrm{i}\}}\right)-\rho\left(\mathrm{Y}_{\mathrm{S}}\right), S \subseteq N$, akkor $\varphi_{i}\left(X_{N}^{\rho}\right) \leq \varphi_{i}\left(Y_{N}^{\rho}\right)$

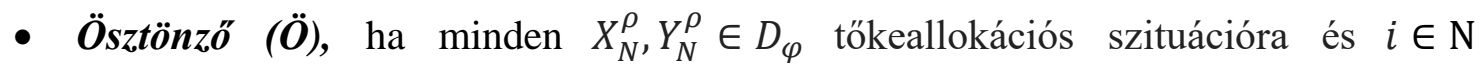
alegységre, amennyiben $\mathrm{X}_{\mathrm{i}} \leq \mathrm{Y}_{\mathrm{i}}$ és $\mathrm{X}_{\mathrm{j}}=\mathrm{Y}_{\mathrm{j}}, j \in \mathrm{N} \backslash\{i\}$, akkor $\varphi_{i}\left(X_{N}^{\rho}\right) \geq \varphi_{i}\left(Y_{N}^{\rho}\right)$;

\footnotetext{
${ }^{15}$ Felmerülhetne még esetleg a folytonosság követelménye, amelyet korábban Kalkbrener (2005) vizsgált, azonban az általa végzett vizsgálat a dekompozíció invariancia tulajdonságra épül, vagyis e tulajdonság teljesítését alapfeltételnek veszi, $\mathrm{s}$ a folytonosságot is ennek szellemében vizsgálja (hogyan változik egy adott alegységre eső kockázat, az adott alegység kismértékü változása mellett). Mint látni fogjuk pont a dekompozíció invariancia viszont önmagában is olyan tulajdonság, amely általánosságban jobb, ha nem teljesül.

${ }^{16}$ A nemnegativitás a gyakorlatban sokszor szükséges elvárás, azonban matematikailag a vizsgálata értelmetlen, minden módszer allokálhat negatív tökét bizonyos esetekben (maga az önálló kockázat is lehet negatív).
} 
- Hatékony $(\boldsymbol{H})$, ha minden $X_{N}^{\rho} \in D_{\varphi}$ tőkeallokációs szituációra $\sum_{i \in N} \varphi_{i}\left(X_{N}^{\rho}\right)=$ $\rho\left(\mathrm{X}_{\mathrm{N}}\right)$

- Egyenlöen kezelö (EK), ha minden $X_{N}^{\rho} \in D_{\varphi}$ tőkeallokációs szituációra és $i, j \in \mathrm{N}$ alegységre amennyiben $\rho\left(\mathrm{X}_{\mathrm{S} \cup\{i\}}\right)-\rho\left(\mathrm{X}_{\mathrm{S}}\right)=\rho\left(\mathrm{X}_{\mathrm{S} \cup\{j\}}\right)-\rho\left(\mathrm{X}_{\mathrm{S}}\right), \quad S \subseteq N \backslash\{i, j\}$, akkor fennáll, hogy $\varphi_{i}\left(X_{N}^{\rho}\right)=\varphi_{j}\left(X_{N}^{\rho}\right)$;

- Kockázatmentes $(\mathbf{K m})$ allokációt eredményez, ha minden $X_{N}^{\rho} \in D_{\varphi}$ tőkeallokációs szituációra és $i \in \mathrm{N}$-re igaz, hogy amennyiben létezik olyan $\mathrm{c}_{\mathrm{i}} \in \mathbb{R}$, amire $\mathrm{X}_{\mathrm{i}}=$ $c_{\mathrm{i}} \chi_{\Omega}$, akkor $\varphi_{i}\left(X_{N}^{\rho}\right)=-c_{\mathrm{i}}$, ahol $\chi_{\Omega}$ továbbra is egy csupa 1-esekböl álló vektor;

- Kovariáns $(\boldsymbol{K})$, ha minden $X_{N}^{\rho} \in D_{\varphi}$ tökeallokációs szituációra, $\alpha \geq 0$ és $\beta \in \mathbb{R}^{N}$ mellett igaz, hogy $\varphi\left(\left(\sum_{i \in N}\left(\alpha X_{i}+\beta_{i} \chi_{\Omega}\right)\right)_{N}^{\rho}\right)=\alpha \varphi\left(X_{N}^{\rho}\right)-\beta$;

- Dekompozíció invariáns $(\boldsymbol{D I})$, ha minden $X_{N}^{\rho}, Y_{N}^{\rho} \in D_{\varphi}$ tőkeallokációs szituációra, ha $X_{i}=Y_{i}$ és $X_{N}=Y_{N}$, akkor $\varphi_{i}\left(X_{N}^{\rho}\right)=\varphi_{i}\left(Y_{N}^{\rho}\right)$.

A tulajdonságok értelmezése a következö.

Egy módszer mindig értelmezett, ha a tőkeallokációs szituációk teljes tartományán értelmezett, minden koherens kockázatmérték mellett és minden lehetséges portfólióra. Amennyiben az értelmezési tartományt nem veszi figyelembe, az alkalmazó nem várt problémákba ütközhet az alkalmazás során.

A diverzifikáló tulajdonság (ld. pl. Kalkbrener, 2005) a magbeliség gyengébb megfelelöje. A követelménynek akkor tesz eleget egy módszer, ha egyrészt hatékony, azaz pontosan a fö egység kockázatát osztja szét az alegységek között (ld. lejjebb), másrészt pedig legfeljebb annyi kockázatot allokál az egyes alegységekre, mint amennyi az önálló kockázatuk, azaz egyéni szinten érvényesül valamilyen diverzifikációs hatás. Az utóbbi tulajdonságot individuális racionalitásnak is nevezi az irodalom - vagyis az adott egység számára 
„racionális döntés” a nagykoalícióban való részvétel, hiszen az így rá allokált kockázat alacsonyabb, mint az önálló kockázata. Ahogyan Homburg és Scherpereel (2008) valós szereplők segítségével végzett kísérlete is alátámasztotta, a valós gazdasági szereplők korlátozott racionalitása miatt az elosztás „észlelt” igazságosságát ez a követelmény nagyban befolyásolja - jobban is, mint az ezt a fajta ,,igazságosságot” minden lehetséges koalíció szintjén is megkövetelő magbeliség.

A magbeliség (más szerzők, pl. Denault, 2001, Buch és Dorfleitner, 2008 „No undercut” néven hivatkoznak e tulajdonságra) akkor teljesül, ha az allokáció minden szituációban stabil: a teljes portfólió kockázata felosztásra kerül (hatékony), és nincs olyan koalíciója az alegységeknek, amely érdekelt lenne az elosztás visszautasításában amiatt, hogy a koalíció kockázata kisebb, mint amennyi a tagjaira allokált tőke összege. Azaz a diverzifikáló tulajdonsággal szemben, ahol ez csak egyes alegységek szintjén, „,individuálisan” elvárt, ez a követelmény a koalíciók szintjén is teljesül (nevezhetnénk koalíciós racionalitásnak is). Denault (2001), Csóka et al. (2009), valamint illikvid portfóliókra Csóka és Herings (2014) megmutatják, hogy a kockázatot mindig lehetséges ilyen módon szétosztani. Csóka és Pintér (2016) pedig bebizonyítja, hogy a követelményt úgy is meg lehet fogalmazni, hogy minden koalícióra legalább annyi kockázatot kell allokálni, amennyivel a koalíció megnöveli a rajta kívül álló alegységek kockázatát azokhoz csatlakozva. Hougard és Smilgins (2016) úgy értelmezi a magbeliséget, hogy egyik koalíció sem nyújt támogatást másik koalíciónak.

Az erős monotonitás (Young, 1985; Csóka és Pintér, 2016) követelménye szerint két tőkeallokációs szituáció azonos kockázatmérték, de eltérő portfóliók esetén történő összehasonlításakor, amennyiben egy alegység hozzájárulása a többi alegység kockázatához (illetve alegységekből álló koalíció kockázatához; beleértve az üres halmazt is, vagyis a szóban forgó egység önálló kockázatát) nem csökken, akkor a rá allokált kockázat sem 
csökkenhet. Ezáltal az alegységek nem motiváltak a kockázatuk növelésére, vagy a többi koalíció kockázatához való hozzájárulásuk növelésére ${ }^{17}$.

Az ösztönzés követelményét implicit módon Csóka és Pintér (2016, 3.8. példa) vezette be, és azt jelenti, hogy ha a tőkeallokációs szituáció úgy változik, hogy csak egy alegység kockázata változik, mégpedig gyengén csökken, akkor a rá allokált kockázat nem nőhet. A tulajdonságot portfólió monotonitásnak is nevezhetnénk. Vegyük észre, hogy az erős monotonitásból következik az ösztönzés, de fordítva nem. Ennek az az oka, hogy ha egy alegység hozameloszlása nem növekvő az összes lehetséges világállapotban, akkor a koherens kockázatmértékek monotonitás tulajdonságából adódóan sem az adott alegység kockázata, sem a többi koalícióhoz való kockázati hozzájárulása nem nőhet. Kicsit konkrétabban, tegyük fel, hogy teljesül az erős monotonitás feltétele és az ösztönzést szeretnénk ellenőrizni, $X_{i} \geq Y_{i}$ tetszőleges i-re, és $\mathrm{X}_{\mathrm{j}}=\mathrm{Y}_{\mathrm{j}}, j \in \mathrm{N} \backslash\{\mathrm{i}\}$-re. Ekkor a koherens kockázati mértékek monotonitása miatt $\rho\left(X_{i}\right) \leq \rho\left(Y_{i}\right)$, és az erös monotonitás definíciójában szereplő $\mathrm{S}$ halmazt az üreshalmaznak választva az ösztönzés is teljesül. Könnyen látható, hogy ugyanakkor az ösztönzés feltételeinek való megfelelés nem garantálja az erős monotonitást. Az ösztönzés egy igen érdekes tulajdonság: még a mögöttes intuícióját tekintve egy meglehetősen gyenge és magától értetődő tulajdonság (ha egy alegység realizációs vektora minden lehetséges kimenetel esetén gyengén csökkenő, akkor elvárható, hogy a rá allokált kockázat ne csökkenjen), mint látni fogjuk, a vizsgált módszerek közül mindössze egy felel meg ennek a követelménynek.

A hatékonyság elvárása ezt jelenti, hogy a fö egység kockázatát teljesen szét kell osztani az alegységek között, s az alkalmazások során az esetek nagy részében teljesen alapvető

\footnotetext{
$17 \mathrm{Az}$ erős monotonitás szigorúbban is definiálható, ha a két szituációban különböző koherens kockázatmértékek alkalmazását is megengedjük, de e számunka elegendő a fent megadott módon definiált kritérium.
} 
elvárásként kezeljük. Következik mind a magbeliségből, mind pedig a diverzifikáló tulajdonságból, de mint látni fogjuk a 19. táblázatban, érdemes külön is vizsgálni.

Az egyenlöen kezelés (az axiómára Denault, 2001 és Buch és Dorfleitner ${ }^{18}$, 2008 szimmetria néven hivatkozik) azt biztosítja, hogy ekvivalens alegységeket ugyanúgy kezeljünk, azaz, ha két alegység minden őket nem tartalmazó koalíció kockázatát ugyanannyival növeli ${ }^{19}$, akkor a rájuk allokált tőke is egyezzen meg. Van Gulick et al. (2012) csak azt várja el, hogy egyforma alegységekre ugyanannyi kockázatot allokáljon a módszer, ami egyértelmüen gyengébb követelmény.

A kockázatmentes portfólió követelménye (van Gulick et al., 2012 és Boonen et al., 2012) amely Denult-nál (2001) „dummy” játékos tulajdonság, Buch és Dorfleitner-nél (2008) pedig kockázatmentes allokáció tulajdonság néven szerepel - elvárja, hogy egy olyan alegységre, amelynek a hozama biztos (minden világállapotban azonos), annyi tőkét allokáljon a módszer, mint amennyi a biztosan várható hozam értékének ellentettje. Ez a koherens kockázatmértékek transzláció invariancia axiómájából adódóan megegyezik az alegység egyedi kockázatával. Hougaard és Smilgins (2016) megmutatják, hogy a magbeliségből következik a kockázatmentes portfólió tulajdonság. Természetesen (ahogy látni fogjuk az 19. táblázatban) a kockázatmentes portfólió tulajdonság nem implikálja a magbeliséget.

A kovariancia két széles körben használt kritériumból tevődik össze: a skála invarianciából és a transzláció invarianciából (van Gulick et al., 2012 és Boonen et al., 2012). A skála invariancia azt várja el, hogy az allokáció legyen invariáns a portfóliók nemnegatív skalárral való szorzására. A transzláció invariancia pedig azt mondja ki, hogy ha egy adott

\footnotetext{
${ }^{18}$ Buch és Dorfleitner (2008) definíciója kis hibát tartalmaz, M halmaz sem i-t, sem j-t nem tartalmazhatja.

${ }^{19}$ Beleértve az üres halmazt is, vagyis a két egység önálló kockázata is megegyezik.
} 
alegységhez hozzáadunk (elveszünk) egy olyan portfóliót, melynek értéke minden világállapotban azonos, biztos (a kockázatmentes portfólió követelményéhez hasonlóan), akkor az adott alegységre allokált kockázat a kockázatmentes portfólió kockázatával megegyezően változzon. A kovarianciához hasonló, de erősebb kritérium a Kalkbrener (2005) által definiált lineáris aggregáció, ahol a skalárral való szorzás és az eltolás is alegységenként változó valós skalárral történhet.

A dekompozíció invariancia (amelyet Kalkbrener, 2005 alapfeltételként értelmez) követelménye akkor teljesül, ha az egyes alegységekre allokált tőke kizárólag az adott alegység és a fö egység hozameloszlásától függ, a többi alegységétől nem. A dekompozíció pont azt várja el tehát, hogy ne vegyük figyelembe az egyes alegységek közötti függőségi struktúrát (amelyből a diverzifikációs megtakarítás is adódhat a teljes portfólió szintjén), emiatt tehát e tulajdonság teljesítése elméletben nem magától értődően kívánatos. Ugyanakkor a valóságban könnyen elképzelhető olyan szituáció, amikor azt szeretnénk, hogy egy adott alegységre allokált tőke csak a saját és a teljes portfólió kockázatától függjön, és ne változzon meg a portfólió más részeinek átrendeződésekor.

Az alábbi ábrán foglaljuk össze az egyes tulajdonságok közötti kapcsolatot. Vegyük észre, hogy az ösztönzés, a kovariancia, a kockázatmentes portfólió és a dekompozíció invariancia követelmények közvetlenül a portfóliókon definiáltak, és explicit módon nem használják a kockázatmértéket. A további tulajdonságok a kooperatív játékelmélethez köthetőek, az egyes alegységek kockázatát veszik figyelembe. 


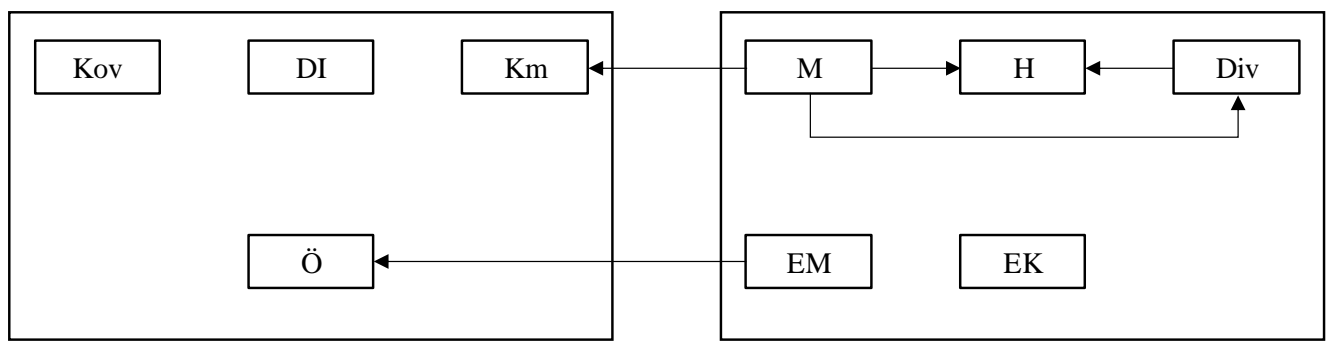

Végül, egy fontos tétel a fenti tulajdonságokhoz kapcsolódóan.

2.1.3. tétel (Csóka és Pintér, 2016, 3.7. és 3.8 tétel). A tőkeallokációs szituációk osztályán nincs olyan tőkeallokációs módszer, amely teljesíti a mindenhol értelmezettség, a magbeliség és ösztönzés tulajdonságokat.

Az, hogy nem lehetséges egyszerre teljesíteni a mindenhol értelmezettség, a magbeliség és ösztönzés tulajdonságokat - melyek meglehetősen természetes elvárások, ha igazságosan szeretnénk elosztani a kockázatot -, problémát jelent, hiszen így az alkalmazónak döntenie kell, hogy melyiket adja fel közülük. A további hét tulajdonság vizsgálatával ehhez a döntéshez szeretnénk segítséget nyújtani.

\subsection{A HÉT MÓDSZER ANALITIKUS ELEMZÉSÉNEK EREDMÉNYEI}

Ebben a részben bemutatjuk a hét tőkeallokációs módszert, és megmutatjuk, mely tulajdonságokat sértenek meg és melyeknek tesznek eleget értelmezési tartományukon. Az első négy módszert Homburg és Scherpereel-t (2008) követve adjuk meg (kissé módosítva). Az ötödik módszernek, a marginális kockázati hozzájárulásnak két verziója létezik: megadhatjuk parciális és iránymenti deriváltként is. Az utolsó két módszer, a Shapley(Shapley, 1953) és a nukleolusz (Schmeidler, 1969) módszerek jól ismertek a 
játékelméletböl. A tulajdonságok elemzése során végig új eredményeket közlünk, kivéve ahol ezt külön jelezzük.

Hogy a vizsgált kérdés egyértelmübb legyen, az alábbiakban bemutatjuk, hogy az elemzendő hét módszer (ld. a következő fejezetben) hogyan osztja szét a kockázatot a 2.1.1. példában bemutatott tőkeallokációs szituációban. Szintén ezt a példát fogjuk használni a béta módszer (2.2.2. fejezet), a növekményi módszer (2.2.3. fejezet) és a marginális kockázati hozzájárulás (2.2.5. fejezet) tárgyalásakor.

2.2.1. példa (2.1.1. példa folytatása). A 2.1.1. példában a vizsgálandó hét módszer az alábbiak szerint osztja szét a kockázatot.

5. táblázat: A 2.1.1. példabeli kockázati tőke allokációja

\begin{tabular}{|c|c|c|c|}
\hline Módszer / alegység & 1 & 2 & 3 \\
\hline Egyéni kockázattal arányos & 8,9617 & 8,9617 & 89,1667 \\
\hline Béta & $-8,7390$ & $-8,2969$ & 124,0359 \\
\hline Növekményi & 2,3516 & 2,3516 & 102,2967 \\
\hline Költségrés & 6,4138 & 6,4138 & 94,1724 \\
\hline Marginális kockázati hozzájárulás & 3 & 4 & 100 \\
\hline Shapley & 6,5 & 6,5 & 94 \\
\hline Nukleolusz & 6 & 6 & 95 \\
\hline \multicolumn{2}{|c|}{} \\
\hline
\end{tabular}




\subsubsection{EGYÉNI KOCKÁZATTAL ARÁNYOS MÓDSZER}

A módszert először Hamlen et al. (1997) tárgyalta. A módszer a közös kockázatot az egyes alegységek egyedi, önálló kockázata alapján osztja szét. $\mathrm{Az} X_{N}^{\rho} \in R C A S_{N}$ tőkeallokációs szituáció esetén az $i \in N$ alegységhez a módszer az alábbi tőke mennyiséget rendeli:

$$
\varphi_{i}^{E k}\left(X_{N}^{\rho}\right)=\frac{\rho\left(X_{i}\right)}{\sum_{j \in N} \rho\left(X_{j}\right)} \cdot \rho\left(X_{N}\right) .
$$

A módszer meglehetősen komoly hátránya, hogy nem veszi figyelembe az egyes eszközök közötti függőségi struktúrát. A tulajdonságait a következő állításban foglaljuk össze.

2.2.2. állítás. $A z$ egyéni kockázattal arányos módszer eleget tesz a $H$ és $E K$ követelményeknek, de nem teljesíti az MÉ, M, Div, Ö, EM, Km, K és DI kritériumokat.

Bizonyitás. A H és EK követelményeknek való megfelelés a definícióból adódik. MÉ nem teljesül, mivel $\sum_{j \in N} \rho\left(X_{j}\right)$ értéke lehet 0 . A Div $(\mathrm{M})$, Ö (EM), Km és K tulajdonságokra vonatkozóan tekintsük a következő példát.

2.2.3. példa. Tekintsük az $X_{N}^{\rho}$ és az $Y_{N}^{\rho}$ tőkeallokációs szituációkat, ahol mindkét esetben $\Omega=\left\{\omega_{1}, \omega_{2}\right\}$, P pedig olyan, hogy $P=P\left(\left\{\omega_{1}\right\}\right)=P\left(\left\{\omega_{2}\right\}\right)=1 / 2$. Három alegységünk van, $N=\{1,2,3\}$, és az alkalmazott $\rho$ kockázatmérték az 50\%-Expected Shortfall (ismét a 
maximális veszteség). Az $X_{N}^{\rho}$ és az $Y_{N}^{\rho}$ tőkeallokációs szituációkat és az egyéni kockázattal arányos módszer által allokált tőkét az alábbi táblázat tartalmazza.

6. táblázat: Az egyéni kockázattal arányos módszer nem teljesíti a diverzifikáló, magbeli, ösztönzö, erősen monoton, kockázatmentes és kovariáns tulajdonságokat

\begin{tabular}{|c|c|c|c|c||c|c|c|c|c|}
\hline $\boldsymbol{\Omega} / \boldsymbol{X}_{\boldsymbol{S}}$ & $X_{1}$ & $X_{2}$ & $X_{3}$ & $X_{\{1,2,3\}}$ & $\boldsymbol{\Omega} / \boldsymbol{Y}_{\boldsymbol{S}}$ & $Y_{1}$ & $Y_{2}$ & $Y_{3}$ & $Y_{\{1,2,3\}}$ \\
\hline \hline $\boldsymbol{\omega}_{1}$ & 3 & -2 & -5 & -4 & $\boldsymbol{\omega}_{1}$ & 3 & -2 & -5 & -4 \\
\hline $\boldsymbol{\omega}_{2}$ & 3 & 10 & -6 & 7 & $\boldsymbol{\omega}_{2}$ & 3 & 10 & -7 & 6 \\
\hline $\boldsymbol{\rho}\left(\boldsymbol{X}_{\boldsymbol{S}}\right)$ & -3 & 2 & 6 & 4 & $\boldsymbol{\rho}\left(\boldsymbol{Y}_{\boldsymbol{S}}\right)$ & -3 & 2 & 7 & 4 \\
\hline \hline $\boldsymbol{\varphi}_{\boldsymbol{i}}^{\boldsymbol{E k}}\left(\boldsymbol{X}_{\boldsymbol{N}}^{\boldsymbol{\rho}}\right)$ & $-2,4$ & 1,6 & 4,8 & & $\boldsymbol{\varphi}_{\boldsymbol{i}}^{\boldsymbol{E} \boldsymbol{k}}\left(\boldsymbol{Y}_{\boldsymbol{N}}^{\boldsymbol{\rho}}\right)$ & -2 & $4 / 3$ & $14 / 3$ & \\
\hline
\end{tabular}

A módszer a Div (így M, szintén ld. a szimulációs eredményeket az 2.3. fejezetben) tulajdonságot nem teljesíti, mivel az $X_{N}^{\rho}$ tőkeallokációs szituációban $\rho\left(X_{1}\right)=-3<-2.4=$ $\varphi_{1}^{E k}\left(X_{N}^{\rho}\right)$

A két tőkeallokációs szituációt összevetve láthatjuk, hogy $X_{1}=Y_{1}, X_{2}=Y_{2}$, de $X_{3} \geq Y_{3}$, a 3. alportfólió rosszabb az $Y_{N}^{\rho}$, mint az $X_{N}^{\rho}$ szituációban. Ugyanakkor $\varphi_{3}^{E k}\left(X_{N}^{\rho}\right)=4,8>$ $\frac{14}{3}=\varphi_{3}^{E k}\left(Y_{N}^{\rho}\right)$, azaz az egyéni kockázattal arányos módszer nem Ö (és így nem is EM).

A Km tulajdonság sem teljesül, mivel az 1. alportfólió mindkét világállapotban 3-at ér, de a rá allokált kockázat nem $-3 .^{20}$

Hogy világos legyen, a $\mathrm{K}$ feltétel miért nem teljesül, változtassuk meg $X_{1}$-et $(0,0)$-ra. Így az első egység önálló kockázata és a rá allokált kockázat is 0 , azaz a transzláció invariancia sérül.

\footnotetext{
${ }^{20}$ Mivel M-ből következik Km, a Km megsértéséből következik, hogy M sem teljesül. Ugyanez az érvelés alkalmazható a béta és a növekményi módszer esetében is.
} 
A DI vonatkozásában hagyjunk mindent változatlanul a fenti példában, de cseréljük fel $X_{2}$ és $X_{3}$ értékét az első világállapotban, melynek eredményeképp a 7. táblázatban szereplő $Y_{N}^{\rho}$ szituációt kapjuk. Összevetve a két szituációt, világos, hogy $X_{1}=Y_{1}, X_{N}=Y_{N}$, de $\varphi_{1}^{E k}\left(X_{N}^{\rho}\right)=-2,4 \neq-1,5=\varphi_{1}^{E k}\left(Y_{N}^{\rho}\right)$, azaz a DI feltétel nem teljesül.

7. táblázat: Az egyéni kockázattal arányos módszer nem teljesíti a dekompozíció invariancia tulajdonságot

\begin{tabular}{|c|c|c|c|c|}
\hline $\boldsymbol{\Omega} / \boldsymbol{Y}_{\boldsymbol{S}}$ & $Y_{1}$ & $Y_{2}$ & $Y_{3}$ & $Y_{\{1,2,3\}}$ \\
\hline \hline $\boldsymbol{\omega}_{1}$ & 3 & -5 & -2 & -4 \\
\hline $\boldsymbol{\omega}_{2}$ & 3 & 10 & -6 & 7 \\
\hline \hline $\boldsymbol{\rho}\left(\boldsymbol{Y}_{\boldsymbol{S}}\right)$ & -3 & 5 & 6 & 4 \\
\hline \hline $\boldsymbol{\varphi}_{\boldsymbol{i}}^{\boldsymbol{E}}\left(\boldsymbol{Y}_{\boldsymbol{N}}^{\boldsymbol{\rho}}\right)$ & $-1,5$ & 2,5 & 3 & \\
\hline
\end{tabular}

\subsubsection{BÉTA MÓDSZER}

Legyen $X_{N}^{\rho} \in R C A S_{N}$ egy tőkeallokációs szituáció, és jelölje $\operatorname{Cov}\left(X_{i}, X_{N}\right)$ a kovarianciát az $i$ alegység és a fő egység hozamát leíró valószínüségi változók között. Legyen az $i$ egység bétája $\beta_{i}=\frac{\operatorname{Cov}\left(X_{i}, X_{N}\right)}{\operatorname{Cov}\left(X_{N}, X_{N}\right)}$. Ekkor az $X_{N}^{\rho} \in R C A S_{N}$ tőkeallokációs szituáció esetén a béta módszer szerint az $i \in N$ alegység kockázata:

$$
\varphi_{i}^{B}\left(X_{N}^{\rho}\right)=\frac{\beta_{i}}{\sum_{j \in N} \beta_{j}} \cdot \rho\left(X_{N}\right)
$$

A béta módszer tulajdonságait a következőkben foglaljuk össze.

2.2.4. állítás. A béta módszer eleget tesz a H és a DI feltételeknek, de nem teljesíti az MÉ, M, Div, EM, Ö, EK, Km és K kritériumokat. 
Bizonyitás. A módszer a definíciójából következően H. DI is teljesül, mivel $\sum_{j \in N} \beta_{j}=1$ mindig fennáll.

A módszer nem mindig definiált, így a mindig értelmezettség nem teljesül. Például, ha a fő egység realizációs vektora minden világállapotban ugyanaz, akkor a béta nem definiált, így a képlet nem alkalmazható. A Div (így M), az Ö (így EM), a Km és K tulajdonságokra vonatkozóan tekintsük az alábbi példát.

2.2.5. példa. Tekintsük ismét a 2.2.3. példában szereplö $X_{N}^{\rho}$ és az $Y_{N}^{\rho}$ tökeallokációs szituációkat, melyet a lenti táblázatban ismét megjelenítünk.

8. táblázat: A béta módszer nem teljesiti a diverzifikáló, magbeli, ösztönzö, erősen monoton, kockázatmentes és kovariáns tulajdonságokat

\begin{tabular}{|c|c|c|c|c||c|c|c|c|c|}
\hline $\boldsymbol{\Omega} / \boldsymbol{X}_{\boldsymbol{S}}$ & $X_{1}$ & $X_{2}$ & $X_{3}$ & $X_{\{1,2,3\}}$ & $\boldsymbol{\Omega} / \boldsymbol{Y}_{\boldsymbol{S}}$ & $Y_{1}$ & $Y_{2}$ & $Y_{3}$ & $Y_{\{1,2,3\}}$ \\
\hline \hline $\boldsymbol{\omega}_{\boldsymbol{1}}$ & 3 & -2 & -5 & -4 & $\boldsymbol{\omega}_{1}$ & 3 & -2 & -5 & -4 \\
\hline $\boldsymbol{\omega}_{2}$ & 3 & 10 & -6 & 7 & $\boldsymbol{\omega}_{2}$ & 3 & 10 & -7 & 6 \\
\hline \hline $\boldsymbol{\rho}\left(\boldsymbol{X}_{\boldsymbol{S}}\right)$ & -3 & 2 & 6 & 4 & $\boldsymbol{\rho}\left(\boldsymbol{X}_{\boldsymbol{S}}\right)$ & -3 & 2 & 7 & 4 \\
\hline \hline $\boldsymbol{\varphi}_{\boldsymbol{i}}^{\boldsymbol{B}}\left(\boldsymbol{X}_{\boldsymbol{N}}^{\boldsymbol{\rho}}\right)$ & 0 & $48 / 11$ & $-4 / 11$ & & $\boldsymbol{\varphi}_{\boldsymbol{i}}^{\boldsymbol{B}}\left(\boldsymbol{Y}_{\boldsymbol{N}}^{\boldsymbol{\rho}}\right)$ & 0 & 4,8 & -0.8 & \\
\hline
\end{tabular}

A Div (és M, ld. a szimulációs eredményeket is az 2.3. fejezetben) nem teljesül, mivel az $X_{N}^{\rho}$ szituációban $\rho\left(X_{1}\right)=-3<0=\varphi_{1}^{B}\left(X_{N}^{\rho}\right)$.

Az Ö (és így az EM) tulajdonságok nem teljesülnek, mivel $X_{1}=Y_{1}, X_{2}=Y_{2}$, de $X_{3} \geq Y_{3}$, $\operatorname{de} \varphi_{3}^{B}\left(X_{N}^{\rho}\right)=-\frac{4}{11}>-0,8=\varphi_{3}^{B}\left(Y_{N}^{\rho}\right)$.

A Km tulajdonság sem teljesül, mivel egy olyan egységnek, amely minden világállapotban ugyanazt a szigorúan pozitív értéket veszi fel (jelen esetben $X_{1}$ és $Y_{1}$ ), a bétája (és így az rá allokált kockázat is) mindig 0 , ami nem egyezik meg az egység önálló kockázatával. 
Ugyanezen érveléssel, ha egy olyan alegység realizációs vektorához, amely minden világállapotban ugyanazt a szigorúan pozitív értéket veszi fel, hozzáadunk egy minden koordinátájában 1 értéket felvevő vektort, akkor az adott egység kockázata nem változik, így nem teljesül a transzláció invariancia, azaz K sem.

Visszatérve a 2.1.1 példára, a béta módszer ott a következőképpen allokálja a kockázatot:

$$
\varphi_{1}^{B}\left(X_{N}^{\rho}\right)=-8,739 ; \varphi_{2}^{B}\left(X_{N}^{\rho}\right)=-8,2969 .
$$

Ebből látható, hogy EK sem teljesül, mivel a módszer különböző kockázatot allokál az 1 és 2 alegységekre, holott ezek egyéni kockázata és a hozzájárulásuk az őket nem tartalmazó koalíciókhoz is azonos.

\subsubsection{NÖVEKMÉNYI MÓDSZER}

A növekményi módszer (ld. pl. Jorion, 2007) az egyes egységekre allokált tőkét az egységek „kockázat növekménye” arányában határozza meg, ahol a „kockázat növekmény” a fö egység kockázatához való hozzájárulást jelenti. Az $X_{N}^{\rho} \in R C A S_{N}$ tőkeallokációs szituáció esetén a növekményi módszer szerint az $i \in N$ alegység kockázata:

$$
\varphi_{i}^{N \ddot{v} v}\left(X_{N}^{\rho}\right)=\frac{\rho\left(X_{N}\right)-\rho\left(X_{N \backslash\{i\}}\right)}{\sum_{j \in N}\left(\rho\left(X_{N}\right)-\rho\left(X_{N \backslash\{j\}}\right)\right)} \cdot \rho\left(X_{N}\right) .
$$

A módszer tulajdonságaira vonatkozóan a következők igazak.

2.2.6. állítás. A növekményi módszer teljesíti a $H$ és EK feltételeket, de nem teljesíti az MÉ, M, Div, EM, Ö, K és DI feltételeket.

Bizonyítás. A H és EK tulajdonságoknak való megfelelés a definícióból látszik.

Ez a módszer sem mindig definiált. Ha például azt a tőkeallokációs szituációt tekintjük, melyben a realizációs mátrix az egységmátrix ellentettje, legalább két világállapot és 
ugyanennyi alegység mellett, a kockázatot pedig a maximális veszteséggel mérjük, akkor minden alegységre $\rho\left(X_{N}\right)-\rho\left(X_{N \backslash\{i\}}\right)=0$, vagyis a fenti formula nem használható, az MÉ tulajdonság nem teljesül.

A Div (és M, ld. a szimulációs eredményeket is az 2.3. fejezetben) nem teljesül, mivel a 2.2.7. példa alapján $\rho\left(X_{3}\right)=100<102,2967=\varphi_{3}^{N}\left(X_{N}^{\rho}\right)$.

Az Ö (és EM) tulajdonságokat az alábbi példa segítségével vizsgáljuk.

2.2.8. példa. Tekintsük az $X_{N}^{\rho}$ és az $Y_{N}^{\rho}$ tőkeallokációs szituációkat, ahol mindkét esetben $\Omega=\left\{\omega_{1}, \omega_{2}\right\}$, P pedig olyan, hogy $P=P\left(\left\{\omega_{1}\right\}\right)=P\left(\left\{\omega_{2}\right\}\right)=1 / 2$. Két alegységünk van, $N=\{1,2\}$, és az alkalmazott $\rho$ kockázatmérték az 50\%-Expected Shortfall (ismét a maximális veszteség). Az $X_{N}^{\rho}$ és az $Y_{N}^{\rho}$ tökeallokációs szituációkat és a növekményi módszer szerint allokált tőkét az alábbi táblázat tartalmazza.

9. táblázat: A növekményi módszer nem teljesiti az ösztönzés és erős monotonitás tulajdonságokat

\begin{tabular}{|c|c|c|c||c|c|c|c|}
\hline $\boldsymbol{\Omega} / \boldsymbol{X}_{\boldsymbol{S}}$ & $X_{1}$ & $X_{2}$ & $X_{\{1,2\}}$ & $\boldsymbol{\Omega} / \boldsymbol{Y}_{\boldsymbol{S}}$ & $Y_{1}$ & $Y_{2}$ & $Y_{\{1,2\}}$ \\
\hline \hline $\boldsymbol{\omega}_{1}$ & -2 & -9 & -11 & $\boldsymbol{\omega}_{1}$ & -2 & -7 & -9 \\
\hline $\boldsymbol{\omega}_{2}$ & -9 & 0 & -9 & $\boldsymbol{\omega}_{2}$ & -9 & 0 & -9 \\
\hline $\boldsymbol{\rho}\left(\boldsymbol{X}_{\boldsymbol{S}}\right)$ & 9 & 9 & 11 & $\boldsymbol{\rho}\left(\boldsymbol{X}_{\boldsymbol{S}}\right)$ & 9 & 7 & 9 \\
\hline \hline $\boldsymbol{\varphi}_{\boldsymbol{i}}^{\boldsymbol{N o v}}\left(\boldsymbol{X}_{\boldsymbol{N}}^{\boldsymbol{\rho}}\right)$ & $11 / 2$ & $11 / 2$ & & $\boldsymbol{\varphi}_{\boldsymbol{i}}^{\boldsymbol{N o ̈ v}}\left(\boldsymbol{Y}_{\boldsymbol{N}}^{\boldsymbol{\rho}}\right)$ & 0 & 9 & \\
\hline
\end{tabular}

Ekkor $X_{2} \leq Y_{2}$, de $\varphi_{2}^{N o ̈ v}\left(X_{N}^{\rho}\right)=\frac{11}{2}<9=\varphi_{3}^{N o ̈ v}\left(Y_{N}^{\rho}\right)$, vagyis a növekményi módszer nem teljesíti az Ö (és így EM) feltételt.

A Km tulajdonság nem-teljesítését az alábbi példán mutatjuk meg. 
2.2.9. példa. Tekintsük az $X_{N}^{\rho}$ tőkeallokációs szituációt, a lehetséges kimentelek halmaza $\Omega=\left\{\omega_{1}, \omega_{2}\right\}$, P pedig olyan, hogy $P=P\left(\left\{\omega_{1}\right\}\right)=P\left(\left\{\omega_{2}\right\}\right)=1 / 2$. Három alegységünk van, $N=\{1,2,3\}$, és az alkalmazott $\rho$ kockázatmérték az 50\%-Expected Shortfall, ami ismét a maximális veszteség. Az $X_{N}^{\rho}$ tőkeallokációs szituációt és a növekményi módszer által allokált tőkét az alábbi táblázat tartalmazza.

10. táblázat: A növekményi módszer nem teljesíti a kockázatmentes tulajdonságot

\begin{tabular}{|c|c|c|c|c|c|c|c|}
\hline $\boldsymbol{\Omega} / \boldsymbol{X}_{\boldsymbol{S}}$ & $X_{1}$ & $X_{2}$ & $X_{3}$ & $X_{\{1,2\}}$ & $X_{\{1,3\}}$ & $X_{\{2,3\}}$ & $X_{\{1,2,3\}}$ \\
\hline \hline$\omega_{1}$ & 1 & -1 & 1 & 0 & 2 & 0 & 1 \\
\hline $\boldsymbol{\omega}_{2}$ & 1 & 3 & -5 & 4 & -4 & -2 & -1 \\
\hline \hline $\boldsymbol{\rho}\left(\boldsymbol{X}_{\boldsymbol{S}}\right)$ & -1 & 1 & 5 & 0 & 4 & 2 & 1 \\
\hline \hline $\boldsymbol{\rho}\left(\boldsymbol{X}_{\boldsymbol{N}}\right)-\boldsymbol{\rho}\left(\boldsymbol{X}_{\boldsymbol{N} \backslash\{\boldsymbol{i}\}}\right)$ & -1 & -3 & 1 & & & & \\
\hline \hline $\boldsymbol{\varphi}_{\boldsymbol{i}}^{\boldsymbol{N o ̈ v}}\left(\boldsymbol{X}_{\boldsymbol{N}}^{\boldsymbol{\rho}}\right)$ & $1 / 3$ & 1 & $-1 / 3$ & & & & \\
\hline
\end{tabular}

Vegyük észre, hogy az első alegység realizációs vektora mindkét világállapotban 1 értéket vesz fel, de a rá allokált kockázat 1/3, nem pedig -1, azaz Km nem teljesül. Szintén figyeljük meg, hogy a példában a kockázatnövekmények összege negatív, és a biztos hozamú 1 . egységet „,bünteti”, miközben a 3. alegységet, amelyhez a legrosszabb lehetséges kimenetel (-5) tartozik, ,jutalmazza” a módszer.

Hogy belássuk a $\mathrm{K}$ feltétel nem-teljesítését, hasonlóan az egyéni kockázattal arányos módszernél bemutatott ellenpéldához, változtassuk meg a 2.2.9. példában az első alegység realizációs vektorát $(0,0)$-ra. Így az alegységnek mind az önálló, mind az allokált kockázata 0 lesz, amivel a transzláció invariancia sérül, így K sem teljesül. 
A DI tulajdonsággal kapcsolatban a 2.2.9. példában tartsunk változatlanul mindent, de cseréljük meg $X_{2}$ és $X_{3}$ értékeit az első világállapotban, ekkor az alábbi $Y_{N}^{\rho}$ tőkeallokációs szituációt kapjuk:

\section{1. táblázat: A növekményi módszer nem dekompozíció invariáns}

\begin{tabular}{|c|c|c|c|c|c|c|c|}
\hline $\boldsymbol{\Omega} / \boldsymbol{Y}_{\boldsymbol{S}}$ & $Y_{1}$ & $Y_{2}$ & $Y_{3}$ & $Y_{\{1,2\}}$ & $Y_{\{1,3\}}$ & $Y_{\{2,3\}}$ & $Y_{\{1,2,3\}}$ \\
\hline \hline $\boldsymbol{\omega}_{1}$ & 1 & 1 & -1 & 2 & 2 & 0 & 1 \\
\hline $\boldsymbol{\omega}_{2}$ & 1 & 3 & -5 & 4 & -4 & -2 & -1 \\
\hline $\boldsymbol{\rho}\left(\boldsymbol{Y}_{\boldsymbol{S}}\right)$ & -1 & -1 & 5 & -2 & 4 & 2 & 1 \\
\hline $\boldsymbol{\rho}\left(\boldsymbol{Y}_{\boldsymbol{N}}\right)-\boldsymbol{\rho}\left(\boldsymbol{Y}_{\boldsymbol{N} \backslash\{\boldsymbol{i}\}}\right)$ & -1 & -3 & 3 & & & & \\
\hline \hline $\boldsymbol{\varphi}_{\boldsymbol{i}}^{\boldsymbol{N o ̈ v}}\left(\boldsymbol{Y}_{\boldsymbol{N}}^{\boldsymbol{\rho}}\right)$ & 1 & 3 & -3 & & & & \\
\hline
\end{tabular}

Összevetve a két szituációt, látható, hogy $X_{1}=Y_{1}, X_{N}=Y_{N}$, de $\varphi_{1}^{N o ̈ v}\left(X_{N}^{\rho}\right)=1 / 3 \neq 1=$ $\varphi_{1}^{N o ̈ v}\left(Y_{N}^{\rho}\right)$, azaz a DI feltétel nem teljesül.

\subsubsection{KÖLTSÉGRÉS MÓDSZER}

A növekményi módszer kis módosításával kapjuk Tijs és Driessen (1986) költségrés módszerét. Elöször is definiáljuk minden $S \subseteq N$ koalícióhoz tartozó költségrést, $\gamma_{S}$-t az alábbiak szerint:

$$
\gamma_{S}=\rho\left(X_{S}\right)-\sum_{j \in S} \rho\left(X_{N}\right)-\rho\left(X_{N \backslash\{j\}}\right) .
$$

A koalícióhoz tartozó költségrés, $\gamma_{S}$ azt mutatja meg, hogy mennyi a különbség a koalíció kockázata és a koalíció tagjainak a nagykoalícióhoz való kockázati hozzájárulásainak összege között. Valójában ez nem más, mint a koalíció nem-szeparálható kockázata (költsége), amely a következö lemma szerint mindig nem-negatív. 
2.2.10. lemma. Bármely $X_{N}^{\rho} \in R C A S_{N}$ tökeallokációs szituáció esetében, minden $S \subseteq N$ koalícióra $\gamma_{S} \geq 0$.

A lemma bizonyítása közvetlenül következik Denault (2001) vagy Csóka et. al. (2009) alapján, mivel a tőkeallokációs szituációk kiegyensúlyozott kooperatív játékokat eredményeznek.

Ez alapján már definiálhatjuk az $i \in N$ egység költségrését, az alábbiak szerint:

$$
\lambda_{i}=\min _{S \subseteq N, i \in S} \gamma_{S}
$$

Az $i$ egység költségrését úgy értelmezhetjük, mintha minden egység az őt tartalmazó koalíciók közül a legkisebb nem-szeparálható kockázattal rendelkezőt keresné. Minél alacsonyabb $\lambda_{i}$, annál jobb az $i$ egység alkupozíciója. Egy $X_{N}^{\rho} \in R C A S_{N}$ tőkeallokációs szituációra és $i \in N$ egységre a költségrés módszert a következöképp definiálhatjuk:

$$
\begin{aligned}
& \varphi_{i}^{K}\left(X_{N}^{\rho}\right) \\
& =\left\{\begin{array}{rr}
\rho\left(X_{N}\right)-\rho\left(X_{N \backslash\{j\}}\right), & \text { ha } \gamma_{N}=0, \\
\rho\left(X_{N}\right)-\rho\left(X_{N \backslash\{j\}}\right)+\frac{\lambda_{i}}{\sum_{j \in N} \lambda_{j}} \cdot\left(\rho\left(X_{N}\right)-\sum_{j \in N}\left(\rho\left(X_{N}\right)-\rho\left(X_{N \backslash\{j\}}\right)\right)\right), & h a \gamma_{N}>0 .
\end{array}\right.
\end{aligned}
$$

Tehát amennyiben a kockázatnövekmények összege kiadja a teljes kockázatot, akkor ez lesz az elosztás, egyéb esetben a nagykoalíció nem-szeparálható költségét adjuk hozzá a növekményhez, a költségrések arányában elosztva.

A módszer tulajdonságait az alábbi állításban összegezzük.

2.2.11. állítás. A költségrés módszer eleget tesz az MÉ, Div, $H, E K, K m$ és $K$ tulajdonságoknak, de nem teljesíti az M, EM, Ö és DI követelményeket.

Bizonyítás. Denault (2001) vagy Csóka et al. (2009) (kiegyensúlyozottság), valamint Tijs és Driessen (1986) (Tijs, 1981 tanulmányára hivatkozva, egy költségfüggvény, melynek a 
magja nem üres, kielégíti a 3.1 feltételüket) alapján következik, hogy MÉ teljesül, de a teljesség és egyértelműség érdekében alább adunk egy bizonyítást.

Tekintsünk egy $X_{N}^{\rho} \in R C A S_{N}$ tőkeallokációs szituációt, melyben $\sum_{i \in N} \lambda_{i}=0$. Az 2.2.10. lemma alapján minden $S \in N$ esetén $\gamma_{\mathrm{S}} \geq 0$, így minden $i \in N$ esetén is $\lambda_{i} \geq 0$, amiből már következik, hogy minden $i \in N$ esetén $\lambda_{i}=0$ is fennáll.

Most megmutatjuk, hogy ez esetben $\rho\left(X_{N}\right)-\sum_{i \in N} \rho\left(X_{N}\right)-\rho\left(X_{N \backslash\{i\}}\right)=0$.

Transzformáljuk $X_{N}^{\rho}$-t $Y_{N}^{\rho} \in R C A S_{N}$ szituációvá a következők szerint. Minden $i \in N$-re legyen $Y_{i}=X_{i}+\left(\rho\left(X_{N}\right)-\rho\left(X_{N \backslash\{i\}}\right)\right) \chi_{\Omega}$ és legyen továbbra is $\rho$ a koherens kockázatmérték. A koherens kockázatmértékek transzláció invariancia tulajdonságából adódóan minden $S \subseteq N$ koalícióra $\rho\left(Y_{S}\right)=\rho\left(X_{S}\right)-\sum_{j \in S}\left(\rho\left(X_{N}\right)-\rho\left(X_{N \backslash\{j\}}\right)\right) \geq 0$. Ekkor (mivel az alkalmazott transzformáció megőrzi a kiegyensúlyozottságot, ld. pl. Peleg és Südholter, 2007) létezik $y \in \mathbb{R}^{N}$, amire $\sum_{i \in N} y_{i}=\rho\left(Y_{N}\right)$ és minden $S \subseteq N$ koalícióra $\sum_{i \in S} y_{i} \leq \rho\left(Y_{S}\right)$. Továbbá $\rho\left(Y_{N}\right)-\rho\left(Y_{N \backslash\{i\}}\right)=0$ minden $i \in N$-re, amiböl következően $0 \leq y_{i}$ minden $i \in N$-re.

Vegyük észre, hogy ha $\rho\left(Y_{S}\right)=0$, akkor $\lambda_{i}=0$ minden $i \in S$-re. Mivel $\lambda_{i}=0$ minden $i \in$ $N$-re, azt kapjuk, hogy minden $i \in N$-re létezik egy olyan $S \subseteq N$ koalíció, hogy $i \in S$ és $\rho\left(Y_{S}\right)=0$. Ezért minden $i \in N$-re $y_{i}=0$, így $\rho\left(Y_{N}\right)=0$, vagyis $\rho\left(X_{N}\right)-\sum_{i \in N} \rho\left(X_{N}\right)-$ $\rho\left(X_{N \backslash\{i\}}\right)=0$, azaz a költségrés módszer minden tőkeallokációs szituációra definiált.

A Div tulajdonság Tijs és Driessen (1986) 3.1 tétele alapján teljesül.

A H és EK kritériumok szintén teljesülnek a módszer definíciójából következően.

A Km tulajdonság vizsgálatához tegyük fel, hogy az $i$ egység hozama biztos (realizációs vektorának minden eleme azonos). Ekkor $S=i$ választásával az $S$ koalíció költségrése 


$$
\gamma_{i}=\rho\left(X_{i}\right)-\left(\rho\left(X_{N}\right)-\rho\left(X_{N \backslash\{i\}}\right)\right)=\rho\left(X_{i}\right)-\left(\rho\left(X_{N}\right)-\left(\rho\left(X_{N}\right)-\rho\left(X_{i}\right)\right)\right)=0,
$$

ahol a második egyenlőség a koherens kockázatmértékek transzláció invariancia tulajdonságból következik. Ezt, valamint a 2.2.10. lemmát felhasználva azt kapjuk, hogy az alegységhez tartozó költségrés értéke 0 . Így tehát az $i$ alegységre a költségrés módszer az általa okozott kockázatnövekményt rendeli, ami, ismét a koherens kockázatmértékek transzláció invariancia tulajdonságát felhasználva, $\rho\left(X_{N}\right)-\rho\left(X_{N \backslash\{i\}}\right)=\rho\left(X_{N}\right)-$ $\left(\rho\left(X_{N}\right)-\rho\left(X_{i}\right)\right)=\rho\left(X_{i}\right)$, azaz a Km feltétel teljesül.

A K tulajdonság elemeiből a skála invariancia definíciószerủen teljesül, csak a transzláció invariancia teljesülését kell ellenőriznünk. Vegyük észre, hogy ha az $i$ alegység realizációs vektorát minden világállapotban egy azonos $\beta_{i}$ skalárral toljuk el, akkor mind az alegység költségrése, mind pedig a nagykoalíció nem-szeparálható kockázata változatlan marad. Ezért egyedül az alegység kockázatnövekményének változásával kell foglalkoznunk, amely ismét a koherens kockázatmértékek transzláció invariancia tulajdonságát használva $-\beta_{i}$, azaz a költségrés módszer eleget tesz a transzláció invariancia feltételének.

Az 2.3. fejezet szimulációs eredményei alapján látható, hogy a módszer nem tesz eleget az M feltételnek, de egy ellenpéldát is mutatunk.

2.2.12. példa. Tekintsük az $X_{N}^{\rho}$ tőkeallokációs szituációt, ahol a $(\Omega, \mathcal{M}, P)$ valószínűségi mezőn $\Omega=\left\{\omega_{1}, \omega_{2}\right\}, P$ pedig olyan, hogy $P=P\left(\left\{\omega_{1}\right\}\right)=P\left(\left\{\omega_{2}\right\}\right)=1 / 2$. Négy alegységünk van, $N=\{1,2,3,4\}$, és az alkalmazott $\rho$ kockázatmérték az 50\%-Expected Shortfall (ismét a maximális veszteség). Az $X_{i}$ vektorokat, valamint ezek összegeit az alábbi 
táblázat tartalmazza. Látható, hogy $\varphi_{1}^{K}\left(X_{N}^{\rho}\right)+\varphi_{4}^{K}\left(X_{N}^{\rho}\right)=\frac{31}{3}>10=\rho\left(X_{\{1,4\}}\right)$, így M nem teljesül ${ }^{21}$.

12. táblázat: Egy $X_{N}^{\rho}$ tôkeallokációs szituáció, ahol a költségrés módszer nem magbeli allokációt eredményez

\begin{tabular}{|c|c|c|c|c|c|}
\hline $\boldsymbol{\Omega} / \mathrm{S}$ & $\{1\}$ & $\{2\}$ & $\{3\}$ & $\{4\}$ & $\{1,2,3,4\}$ \\
\hline $\boldsymbol{\omega}_{\boldsymbol{1}}$ & 3 & -6 & 3 & -13 & -13 \\
\hline $\boldsymbol{\omega}_{2}$ & -4 & 7 & -4 & -2 & -3 \\
\hline $\boldsymbol{\rho}\left(\boldsymbol{X}_{\boldsymbol{S}}\right)$ & 4 & 6 & 4 & 13 & 13 \\
\hline \hline $\boldsymbol{\varphi}_{\boldsymbol{i}}^{\boldsymbol{K}}\left(\boldsymbol{X}_{\boldsymbol{N}}^{\boldsymbol{\rho}}\right)$ & $-7 / 3$ & 5 & $-7 / 3$ & $38 / 3$ & \\
\hline
\end{tabular}

Az Ö (és EM) tulajdonságokra vonatkozóan az alábbi példát hozzuk.

2.2.13 példa. Tekintsük az $X_{N}^{\rho}$ és az $Y_{N}^{\rho}$ tőkeallokációs szituációkat, ahol mindkét esetben a $(\Omega, \mathcal{M}, P)$ valószínűségi mezőn $\Omega=\left\{\omega_{1}, \ldots, \omega_{7}\right\}$, P pedig olyan, hogy $P=P\left(\left\{\omega_{1}\right\}\right)=$ $\cdots=P\left(\left\{\omega_{7}\right\}\right)=1 / 7$. Négy alegységünk van, $N=\{1,2,3,4\}$, és az alkalmazott $\rho$ kockázatmérték a 90\%-Expected Shortfall (ismét a maximális veszteség). Az $X_{i}$ és $Y_{i}$ vektorokat, valamint ezek összegeit az alábbi táblázat tartalmazza. Az $X$ és $Y$ realizációs mátrixok között az egyetlen különbség, hogy $Y$-nál az $\omega_{6}$ világállapotban a 4 . alegység hozamát 1-gyel csökkentettük, ezért a továbbiakban csak a differenciát szerepeltetjük zárójelben.

\footnotetext{
${ }^{21}$ Ugyanez igaz a $\{3,4\}$ koalícióra. A kockázatnövekmények rendre $-3,3,-3$ és 12 , a gammák pedig rendre 1, 3,1 és 1.
} 
13. táblázat: $X_{N}^{\rho}$ és $Y_{N}^{\rho}$ (zárójelben) tökeallokációs szituációk, ahol a költségrés módszer nem ösztönzö

\begin{tabular}{|c|c|c|c|c|c|}
\hline$\Omega / S$ & $\{1\}$ & $\{2\}$ & $\{3\}$ & $\{4\}$ & $\{1,2,3,4\}$ \\
\hline$\omega_{1}$ & -5 & 4 & -3 & 3 & -1 \\
\hline$\omega_{2}$ & 5 & -5 & -3 & 3 & 0 \\
\hline$\omega_{3}$ & 0 & 0 & 0 & 0 & 0 \\
\hline$\omega_{4}$ & -1 & 0 & 1 & -4 & -4 \\
\hline$\omega_{5}$ & -5 & 4 & 3 & -3 & -1 \\
\hline$\omega_{6}$ & 0 & 0 & -5 & $2(1)$ & $-3(-4)$ \\
\hline$\omega_{7}$ & 5 & -5 & 3 & -3 & 0 \\
\hline \hline $\boldsymbol{\rho}\left(X_{S}\right)$ & 5 & 5 & 5 & 4 & 4 \\
\hline$\varphi_{i}^{K}\left(X_{N}^{\rho}\right)$ & 0,5 & 0,5 & 1,5 & 1,5 & \\
\hline \hline $\boldsymbol{\rho}\left(Y_{S}\right)$ & 5 & 5 & 5 & 5 & 4 \\
\hline$\varphi_{i}^{K}\left(\boldsymbol{Y}_{N}^{\boldsymbol{\rho}}\right)$ & $7 / 17$ & $7 / 17$ & $31 / 17$ & $23 / 17$ & \\
\hline
\end{tabular}

A fenti példában azt látjuk, hogy $X_{N}^{\rho}$-ről az $Y_{N}^{\rho}$ szituációra a 4. alegység hozama a 6 . világállapotban csökkent, ugyanakkor a rá allokált kockázat is $\operatorname{csökkent~}^{22}$, mivel $\varphi_{4}^{K}\left(X_{N}^{\rho}\right)=$ $1,5=\frac{23}{17}=\varphi_{4}^{K}\left(Y_{N}^{\rho}\right)$, azaz a költségrés módszer nem Ö (és így nem is EM).

A DI tulajdonság vizsgálatához tekintsük a következő példát.

2.2.14. példa. Tekintsük az $X_{N}^{\rho}$ és az $Y_{N}^{\rho}$ tőkeallokációs szituációkat, ahol mindkét esetben a $\Omega=\left\{\omega_{1}, \omega_{2}, \omega_{3}\right\}$, P pedig olyan, hogy $P=P\left(\left\{\omega_{1}\right\}\right)=P\left(\left\{\omega_{2}\right\}\right)=P\left(\left\{\omega_{3}\right\}\right)=1 / 3$. Három alegységünk van, $N=\{1,2,3\}$, és az alkalmazott $\rho$ kockázatmérték a 70\%-Expected

\footnotetext{
${ }^{22}$ Mind $X_{N}^{\rho}$, mind $Y_{N}^{\rho}$ szituációban a kockázatnövekmény -1 minden alegységre, $\gamma_{1}=\gamma_{2}=3, \gamma_{3}=\gamma_{4}=5 X_{N}^{\rho}$ esetén, $Y_{N}^{\rho}$-nél pedig az egyetlen különbség, hogy $\gamma_{3}=6$.
} 
Shortfall (ismét a maximális veszteség). Az $X_{N}^{\rho}$ és az $Y_{N}^{\rho}$ tőkeallokációs szituációkat, valamint a költségrés módszerrel számított allokált kockázati tőkét az alábbi táblázat tartalmazza:

14. táblázat: A költségrés módszer nem dekompozíció invariáns

\begin{tabular}{|c|c|c|c|c|c|c|c|c|c|}
\hline $\boldsymbol{\Omega} / \boldsymbol{X}_{\boldsymbol{S}}$ & $X_{1}$ & $X_{2}$ & $X_{3}$ & $X_{\{1,2,3\}}$ & $\boldsymbol{\Omega} / \boldsymbol{Y}_{\boldsymbol{S}}$ & $Y_{1}$ & $Y_{2}$ & $Y_{3}$ & $Y_{\{1,2,3\}}$ \\
\hline \hline $\boldsymbol{\omega}_{\mathbf{1}}$ & -5 & 4 & -3 & -4 & $\boldsymbol{\omega}_{\mathbf{1}}$ & -5 & 1 & 0 & -4 \\
\hline $\boldsymbol{\omega}_{\mathbf{2}}$ & 5 & -5 & -3 & -3 & $\boldsymbol{\omega}_{2}$ & 5 & -3 & -5 & -3 \\
\hline $\boldsymbol{\omega}_{\mathbf{3}}$ & -4 & -2 & -3 & -9 & $\boldsymbol{\omega}_{\mathbf{3}}$ & -4 & -1 & -4 & -9 \\
\hline \hline $\boldsymbol{\rho}\left(\boldsymbol{X}_{\boldsymbol{S}}\right)$ & 5 & 5 & 3 & 9 & $\boldsymbol{\rho}\left(\boldsymbol{X}_{\boldsymbol{S}}\right)$ & 5 & 3 & 5 & 9 \\
\hline \hline $\boldsymbol{\varphi}_{\boldsymbol{i}}^{\boldsymbol{K}}\left(\boldsymbol{X}_{\boldsymbol{N}}^{\boldsymbol{\rho}}\right)$ & 3 & 3 & 3 & & $\boldsymbol{\varphi}_{\boldsymbol{i}}^{\boldsymbol{K}}\left(\boldsymbol{Y}_{\boldsymbol{N}}^{\boldsymbol{\rho}}\right)$ & 2,5 & 2 & 4,5 & \\
\hline
\end{tabular}

Összevetve a két tőkeallokációs szituációt ${ }^{23}$ látható, hogy $X_{1}=Y_{1}, X_{N}=Y_{N}$, de $\varphi_{1}^{K}\left(X_{N}^{\rho}\right)=$ $3 \neq 2,5=\varphi_{1}^{K}\left(Y_{N}^{\rho}\right)$, azaz a DI feltétel nem teljesül.

\subsubsection{MARGINÁLIS KOCKÁZATI HOZZÁJÁRULÁS}

A marginális kockázati hozzájárulás népszerűsége ellenére nem egy egységesen definiált módszer, azaz az irodalomban számos különböző formában megtalálható. Mi az alábbiakban mind a parciális, mind az iránymenti deriváltként való értelmezésével foglalkozunk. Mindkét esetben a módszer lényege, hogy a nagykoalíció kockázatának számítása során figyelembe vett világállapotokat használjuk az allokáció során.

${ }^{23} X_{N}^{\rho}$ esetében a kockázatnövekmények rendre 1, 1, 3, a gammák 4, 4, $0 . Y_{N}^{\rho}$ esetében a kockázatnövekmények rendre $1,1,4$, a gammák pedig 3,2, 1 . 
Az első lehetőség az iránymenti deriváltként való értelmezés (1d. pl. Cherny és Orlov, 2011), amely jól mutatja a módszer intuitív tartalmát.

Egy $X_{N}^{\rho} \in R C A S_{N}$ tőkeallokációs szituáció és $i \in N$ alegység esetében a marginális kockázati hozzájárulás, iránymenti deriváltként értelmezve a következöképp allokálja a teljes kockázatot:

$$
\varphi_{i}^{M K H I}\left(X_{N}^{\rho}\right)=\rho^{\prime}\left(X_{N}, X_{i}\right)=\lim _{\varepsilon \rightarrow 0^{+}} \frac{\rho\left(X_{N}+\varepsilon X_{i}\right)-\rho\left(X_{N}\right)}{\varepsilon},
$$

vagyis $\rho^{\prime}\left(X_{N}, X_{i}\right) \rho^{\prime}$ iránymenti deriváltja $X_{N}$ helyen, $X_{i}$ mentén. Az iránymenti deriváltakat gyakran alkalmazzák az operációkutatásban, ld. pl. Girsanov (1972).

A marginális kockázati hozzájárulás megadható egy másik, szűkebb körben értelmezett definíció szerint is. Ez esetben egy $X_{N}^{\rho} \in R C A S_{N}$ tőkeallokációs szituáció és $i \in N$ alegység esetében a marginális kockázati hozzájárulás, parciális deriváltként értelmezve (ld. pl. Denault, 2001, vagy Buch és Dorfleitner, 2008) a következöképp allokálja a teljes kockázatot:

$$
\varphi_{i}^{M K H P}\left(X_{N}^{\rho}\right)=\lim _{\varepsilon \rightarrow 0} \frac{\rho\left(X_{N}+\varepsilon X_{i}\right)-\rho\left(X_{N}\right)}{\varepsilon},
$$

Megjegyezzük, hogy ha minden $i \in N$-re a $\rho$ kockázatmérték iránymenti deriváltja létezik $X_{N}$-ben mind $X_{i}$, mind pedig $-X_{i}$ irányban, és a két derivált egymás ellentettje, akkor definiált $\varphi_{i}^{M K H P}\left(X_{N}^{\rho}\right)$.

Iránymenti deriváltként értelmezve a marginális kockázati hozzájárulást, a következő tulajdonságokkal rendelkezik.

2.2.15. állítás. A marginális kockázati hozzájárulás iránymenti deriváltként értelmezve kielégíti az MÉ, Km, K és DI tulajdonságokat, de nem H, M, Div, EM, Ö és EK. 
Bizonyitás. Cherny és Orlov (2011, p558) megmutatja, hogy a marginális kockázati hozzájárulás iránymenti deriváltként értelmezve mindig definiált, így MÉ teljesül.

A koherens kockázatmértékek pozitív homogenitás és transzláció invariancia tulajdonságából adódóan Km és K teljesül.

DI definíciószerűen fennáll.

A H, M és Div tulajdonságok vizsgálatára vegyük a következő példát.

2.2.16 példa. Tekintsük ismét a 2.2.8. példában szereplő tőkeallokáció szituációt:

15. táblázat. A marginális kockázati hozzájárulás iránymenti deriváltként értelmezve nem teljesíti a hatékony, diverzifikáló és magbeli tulajdonságokat

\begin{tabular}{|c|c|c|c|}
\hline $\boldsymbol{\Omega} / \boldsymbol{Y}_{\boldsymbol{S}}$ & $Y_{1}$ & $Y_{2}$ & $Y_{\{1,2\}}$ \\
\hline \hline $\boldsymbol{\omega}_{1}$ & -2 & -7 & -9 \\
\hline $\boldsymbol{\omega}_{2}$ & -9 & 0 & -9 \\
\hline \hline $\boldsymbol{\rho}\left(\boldsymbol{X}_{\boldsymbol{S}}\right)$ & 9 & 7 & 9 \\
\hline $\boldsymbol{\varphi}_{\boldsymbol{i}}^{\boldsymbol{M} \boldsymbol{K} \boldsymbol{H} \boldsymbol{I}}\left(\boldsymbol{Y}_{\boldsymbol{N}}^{\boldsymbol{\rho}}\right)$ & 9 & 7 & \\
\hline
\end{tabular}

Ekkor $\varphi_{2}^{M K H I}\left(Y_{N}^{\rho}\right)=7$, vagyis $\varphi_{1}^{M K H I}\left(Y_{N}^{\rho}\right)+\varphi_{2}^{M K H I}\left(Y_{N}^{\rho}\right)=16>9=\rho\left(Y_{N}\right)$, azaz H, így M és Div sem teljesül.

Ö és EM vizsgálatához tekintsük a következő példát.

2.2.17. példa. Tekintsük az $X_{N}^{\rho}$ és az $Y_{N}^{\rho}$ tőkeallokációs szituációkat, ahol mindkét esetben az $(\Omega, \mathcal{M}, P)$ valószínüségi mezőn $\Omega$ olyan, hogy $\Omega=\left\{\omega_{1}, \omega_{2}\right\}, \mathcal{M}$ jelöli $\Omega$ lehetséges részhalmazait, $P$ pedig olyan, hogy $P=P\left(\left\{\omega_{1}\right\}\right)=P\left(\left\{\omega_{2}\right\}\right)=1 / 2$. Két alegységünk van, $N=\{1,2\}$, és az alkalmazott $\rho$ kockázatmérték az 50\%-Expected Shortfall (ismét a 
maximális veszteség). Az $X_{N}^{\rho}$ és az $Y_{N}^{\rho}$ tőkeallokációs szituációkat és a marginális kockázati hozzájárulás által allokált tőkét az alábbi táblázat tartalmazza.

16. táblázat: $X_{N}^{\rho}$ és $Y_{N}^{\rho}$ tökeallokációs szituációk, melyekben a marginális kockázati hozzájárulás nem ösztönzö és nem erösen monoton

\begin{tabular}{|c|c|c|c||c|c|c|c|}
\hline $\boldsymbol{\Omega} / \boldsymbol{X}_{\boldsymbol{S}}$ & $X_{1}$ & $X_{2}$ & $X_{\{1,2\}}$ & $\boldsymbol{\Omega} / \boldsymbol{Y}_{\boldsymbol{S}}$ & $Y_{1}$ & $Y_{2}$ & $Y_{\{1,2\}}$ \\
\hline \hline $\boldsymbol{\omega}_{1}$ & 3 & 0 & 3 & $\boldsymbol{\omega}_{1}$ & 3 & 0 & 3 \\
\hline $\boldsymbol{\omega}_{2}$ & 0 & 4 & 4 & $\boldsymbol{\omega}_{2}$ & 0 & 1 & 1 \\
\hline \hline $\boldsymbol{\rho}\left(\boldsymbol{X}_{\boldsymbol{S}}\right)$ & 0 & 0 & -3 & $\boldsymbol{\rho}\left(\boldsymbol{Y}_{\boldsymbol{S}}\right)$ & 0 & 0 & -1 \\
\hline $\boldsymbol{\varphi}_{\boldsymbol{i}}^{\boldsymbol{M K H I}}\left(\boldsymbol{X}_{\boldsymbol{N}}^{\boldsymbol{\rho}}\right)$ & -3 & 0 & & $\boldsymbol{\varphi}_{\boldsymbol{i}}^{M K H I}\left(\boldsymbol{Y}_{\boldsymbol{N}}^{\boldsymbol{\rho}}\right)$ & 0 & -1 & \\
\hline \hline $\boldsymbol{\varphi}_{\boldsymbol{i}}^{M K H P}\left(\boldsymbol{X}_{\boldsymbol{N}}^{\boldsymbol{\rho}}\right)$ & -3 & 0 & & $\varphi_{\boldsymbol{i}}^{M K H P}\left(\boldsymbol{Y}_{\boldsymbol{N}}^{\boldsymbol{\rho}}\right)$ & 0 & -1 & \\
\hline
\end{tabular}

Vegyük észre, hogy a fenti példában a marginális kockázati hozzájárulás két verziója egybeesik, mindkettőt úgy számítjuk, hogy az alegységek portfóliójának értékének ellentettjét vesszük abban a világállapotban, amelyikben a fő egység portfóliójának értéke a legalacsonyabb. Azt látjuk, hogy az $X_{N}^{\rho}$-ről az $Y_{N}^{\rho}$ szituációra áttérve a második alegység hozama a második világállapotban csökken, miközben a rá allokált kockázati tőke 0-ról -1re csökken, ami sérti az Ö (és így az EM) feltételt is.

A 2.2.1. példa alapján látható, hogy a módszer nem EK, mivel az 1. és 2. alegységek kockázata azonos, valamint azonos mértékben növelik az őket nem tartalmazó koalíciók kockázatát, de a rájuk allokált kockázati tőke eltér.

A parciális deriváltként értelmezett marginális kockázati hozzájárulás tulajdonságait az alábbi állításban összegezzük.

2.2.18. állítás. A marginális kockázati hozzájárulás parciális deriváltként értelmezve kielégíti a H, M, Div, Km, K és DI tulajdonságokat, de nem MÉ, EM, Ö és EK. 
Bizonyitás. Buch és Dorfleitner (2008) megmutatta, hogy a módszer H, M (így Div) és Km. A koherens kockázatmértékek pozitív homogenitás és transzláció invariancia tulajdonságából adódóan Km és K teljesül.

DI definíciószerüen fennáll.

MÉ nem teljesül, mivel az Expected Shortfall kockázatmérték nem mindig differenciálható (ld. pl. $Y_{N}^{\rho}$ a 2.2.16. példában). Amennyiben a parciális derivált létezik, akkor egybeesik az ún. Aumann-Shapley értékkel (Aumann és Shapley, 1974; Denault, 2001). Boonen et al. (2012) és Grechuk (2015) kiterjesztette a módszert a koherens kockázatmértékek teljes osztályára. A kiterjesztett verzió tulajdonságainak vizsgálata sokat ígérő jövőbeli kutatási téma.

Az Ö (valamint EM) tulajdonságokra vonatkozóan ismét alkalmazható a 2.2.17. példa.

A 2.2.1. példa pedig ez esetben is mutatja, hogy a módszer nem EK, mivel az 1. és 2. alegységek kockázata azonos, valamint azonos mértékben növelik az őket nem tartalmazó koalíciók kockázatát, de a rájuk allokált kockázati tőke eltér.

\subsubsection{SHAPLEY-MÓDSZER}

A Shapley-módszer (Shapley, 1953) a következőképp allokálja a kockázati tőkét az egyes alegységekre: tetszőleges $X_{N}^{\rho} \in R C A S_{N}$ tőkeallokációs szituáció és $i \in N$ alegység esetében

$$
\varphi_{i}^{S}\left(X_{N}^{\rho}\right)=\sum_{S \subseteq N \backslash\{i\}} \frac{(|S|) ! \cdot(|N|-|S|-1) !}{|N| !}\left(\rho\left(X_{S \cup\{i\}}\right)-\rho\left(X_{S}\right)\right),
$$

ahol $|S|$ a S koalícióban lévő alegységek számát jelöli. 
Shapley 1953-as müvében arra kereste a választ, hogy létezik-e olyan érték, amely egyértelműen reprezentálja azt a hasznosságot, amelyet az adott játékosnak a játékban való részvétel okoz. E probléma megoldására javasolta a később róla elnevezett Shapleymódszert, amely veszi az alegységek összes lehetséges permutációját, és az $i$ egységre annak az őt megelőző alegységekből álló koalíciókhoz való átlagos határ-hozzájárulását allokálja. A tulajdonságait az alábbiakban összegezzük.

2.2.19. állítás. $A$ Shapley érték kielégíti az MÉ, Div, $H, E K, E M, O ̈, K$ és $\mathrm{Km}$ tulajdonságokat, de nem M és DI.

Bizonyitás. Mivel a $\rho$ kockázatmérték mindig definiált, így a határ-hozzájárulásokat és ezek átlagát is mindig ki lehet számítani, így MÉ teljesül.

Szintén teljesül a DI feltétel, ld. pl. Peleg és Sudhölter (2007).

Csóka és Pintér (2016) bebizonyítják, hogy ez az egyetlen módszer, amely teljesíti a H, EK és EM (így Ö) tulajdonságokat.

Továbbá, a módszer definíciójából következik, hogy K és Km is teljesülnek.

Tekintsük az alábbi példát M és DI vizsgálatára.

2.2.20. példa. Tekintsük az $X_{N}^{\rho}$ és az $Y_{N}^{\rho}$ tőkeallokációs szituációkat, ahol mindkét esetben $\Omega=\left\{\omega_{1}, \omega_{2}\right\}, \mathcal{M}$ jelöli $\Omega$ lehetséges részhalmazait, $\mathrm{P}$ pedig olyan, hogy $P=P\left(\left\{\omega_{1}\right\}\right)=$ $P\left(\left\{\omega_{2}\right\}\right)=1 / 2$. Három alegységünk van, $N=\{1,2,3\}$, és az alkalmazott $\rho$ kockázatmérték az 50\%-Expected Shortfall (ismét a maximális veszteség). Az $X_{N}^{\rho}$ és az $Y_{N}^{\rho}$ tőkeallokációs szituációkat és a Shapley-módszer által allokált tőkét az alábbi táblázat tartalmazza. 
17. táblázat: A Shapley-módszer nem magbeli és nem dekompozíció invariáns

\begin{tabular}{|c|c|c|c|c||c|c|c|c|c|}
\hline $\boldsymbol{\Omega} / \boldsymbol{X}_{\boldsymbol{S}}$ & $X_{1}$ & $X_{2}$ & $X_{3}$ & $X_{\{1,2,3\}}$ & $\boldsymbol{\Omega} / \boldsymbol{Y}_{\boldsymbol{S}}$ & $Y_{1}$ & $Y_{2}$ & $Y_{3}$ & $Y_{\{1,2,3\}}$ \\
\hline \hline $\boldsymbol{\omega}_{\boldsymbol{1}}$ & -12 & 5 & 5 & -2 & $\boldsymbol{\omega}_{1}$ & -12 & 22 & -12 & -2 \\
\hline $\boldsymbol{\omega}_{2}$ & -4 & -3 & -3 & -10 & $\boldsymbol{\omega}_{2}$ & -4 & -6 & 0 & -10 \\
\hline $\boldsymbol{\rho}\left(\boldsymbol{X}_{\boldsymbol{S}}\right)$ & 12 & 3 & 3 & 10 & $\boldsymbol{\rho}\left(\boldsymbol{Y}_{\boldsymbol{S}}\right)$ & 12 & 6 & 12 & 10 \\
\hline \hline $\boldsymbol{\varphi}_{\boldsymbol{i}}^{\boldsymbol{S}}\left(\boldsymbol{X}_{\boldsymbol{N}}^{\boldsymbol{\rho}}\right)$ & $5 / 3$ & $5 / 3$ & $20 / 3$ & & $\boldsymbol{\varphi}_{\boldsymbol{i}}^{\boldsymbol{S}}\left(\boldsymbol{Y}_{\boldsymbol{N}}^{\boldsymbol{\rho}}\right)$ & 6 & -4 & 8 & \\
\hline
\end{tabular}

Ekkor a fenti $X_{N}^{\rho}$ szituációban a bal oldalon $\varphi_{1}^{S}\left(X_{N}^{\rho}\right)+\varphi_{3}^{S}\left(X_{N}^{\rho}\right)=\frac{25}{3}>7=\rho\left(X_{\{1.3\}}\right)$, így M nem teljesül.

Összevetve a két tőkeallokációs szituációt látható, hogy $X_{1}=Y_{1}, X_{N}=Y_{N}$, de $\varphi_{1}^{S}\left(X_{N}^{\rho}\right)=$ $5 / 3 \neq 6=\varphi_{1}^{S}\left(Y_{N}^{\rho}\right)$, azaz a DI feltétel nem teljesül.

\subsubsection{NUKLEOLUSZ MÓDSZER}

A nukleolusz módszer (Schmeidler, 1969) a következők szerint határozza meg az egyes egységekre allokált kockázati tőkét: tetszőleges $X_{N}^{\rho} \in R C A S_{N}$ tőkeallokációs szituációra és $i \in N$ alegységre

$$
\varphi_{1}^{N u}\left(X_{N}^{\rho}\right)=\left\{x \in I\left(X_{N}^{\rho}\right): E(x) \geq_{l e x} E(y) \text { minden } y \in I\left(X_{N}^{\rho}\right)-r e\right\}
$$

ahol $\quad I\left(X_{N}^{\rho}\right)=\left\{x \in \mathbb{R}^{N}: \sum_{j \in N} x_{j}=\rho\left(X_{N}\right)\right.$ és minden $j \in N-$ re $\left.x_{j} \leq \rho\left(X_{j}\right)\right\} \quad$ a diverzifikáló allokációk halmaza. $E(x)=\left(\ldots \leq \rho\left(X_{S}\right)-\sum_{i \in N} x_{i} \leq \cdots\right)_{S \subset N}\left(\ldots \leq \rho\left(X_{S}\right)-\right.$ $\left.\sum_{i \in N} x_{i} \leq \cdots\right)$ tartalmazza minden $\mathrm{S}$ koalícióra $\mathrm{S}$ önálló kockázatának és az $\mathrm{S}$ tagjaira allokált kockázatok különbségét (nevezzük „elégedettségnek”) gyengén növekvő sorrendben, $\geq_{\text {lex }}$ pedig a lexikografikus rendezést jelenti. Azaz a módszer lexikografikusan maximalizálja a koalíciók elégedettséget, először a legkisebb elégedettséget, és így tovább. 
Kicsit kevésbé formalizáltan, az elégedettség azt mutatja meg, hogy mennyit nyer egy-egy koalíció a nagykoalícióban való részvétellel; a nukleolusz pedig az az elosztás, melyben a koalíciók elégedettsége bizonyos szempontból maximális (legyen a legalacsonyabb többlet a lehető legnagyobb, majd legyen a második legalacsonyabb többlet is a lehető legnagyobb, és így tovább).

Hasonló módszert (többlet alapú allokáció) vizsgál van Gulick et al. (2012), de az közvetlenül a portfóliókon definiált.

2.2.21. állítás. A nukleolusz módszer teljesíti az MÉ, M, Div, H, EK, Km és K feltételeket, de nem EM, Ö és DI.

Bizonyitás. Csóka et al. (2009) alapján $I\left(X_{N}^{\rho}\right) \neq 0$ egy $X_{\mathrm{N}}^{\rho} \in \operatorname{RCAS}_{\mathrm{N}}$ tőkeallokációs szituációra sem, így a nukleolusz módszer mindig definiált, azaz MÉ teljesül. Közismert (Peleg és Sudhölter, 2007), hogy a módszer EK és M (így Div), de nem Ö (EM) (Young, 1985; Csóka és Pintér, 2016). H definíciószerüen teljesül. Továbbá a koherens kockázatmértékek pozitív homogenitás tulajdonságából és a játékokon érvényes kovarianciájából adódik (Peleg és Sudhölter, 2007), hogy teljesíti a Km és K feltételeket.

DI vizsgálatának érdekében tekintsük az alábbi példát.

2.2.22. példa. Tekintsük ismét a 2.2.20. példából az $X_{N}^{\rho}$ és az $Y_{N}^{\rho}$ tökeallokációs szituációkat, melyeket ismét megjelenítünk az alábbi táblázatban: 
18. táblázat: A nukleolusz módszer nem dekompozíció invariáns

\begin{tabular}{|c|c|c|c|c||c|c|c|c|c|}
\hline $\boldsymbol{\Omega} / \boldsymbol{X}_{\boldsymbol{S}}$ & $X_{1}$ & $X_{2}$ & $X_{3}$ & $X_{\{1,2,3\}}$ & $\boldsymbol{\Omega} / \boldsymbol{Y}_{\boldsymbol{S}}$ & $Y_{1}$ & $Y_{2}$ & $Y_{3}$ & $Y_{\{1,2,3\}}$ \\
\hline \hline $\boldsymbol{\omega}_{1}$ & -12 & 5 & 5 & -2 & $\boldsymbol{\omega}_{1}$ & -12 & 22 & -12 & -2 \\
\hline $\boldsymbol{\omega}_{2}$ & -4 & -3 & -3 & -10 & $\boldsymbol{\omega}_{2}$ & -4 & -6 & 0 & -10 \\
\hline \hline $\boldsymbol{\rho}\left(\boldsymbol{X}_{\boldsymbol{S}}\right)$ & 12 & 3 & 3 & 10 & $\boldsymbol{\rho}\left(\boldsymbol{Y}_{\boldsymbol{S}}\right)$ & 12 & 6 & 12 & 10 \\
\hline \hline $\boldsymbol{\varphi}_{\boldsymbol{i}}^{\boldsymbol{N u}}\left(\boldsymbol{X}_{\boldsymbol{N}}^{\boldsymbol{\rho}}\right)$ & -4 & 6 & 8 & & $\boldsymbol{\varphi}_{\boldsymbol{i}}^{\boldsymbol{N u}}\left(\boldsymbol{Y}_{\boldsymbol{N}}^{\boldsymbol{\rho}}\right)$ & 3 & 3 & 4 & \\
\hline
\end{tabular}

Összevetve a két tőkeallokációs szituációt látható, hogy $X_{1}=Y_{1}, X_{N}=Y_{N}$, de $\varphi_{1}^{N u}\left(X_{N}^{\rho}\right)=$ $-4 \neq 3=\varphi_{1}^{N u}\left(Y_{N}^{\rho}\right)$, azaz a DI feltétel nem teljesül.

\subsubsection{AZ ANALITIKUS EREDMÉNYEK ÖSSZEGZÉSE}

Az analitikus eredményeinket az alábbi táblázatban összegezzük. Az $\sqrt{ }$ jel jelenti, hogy az adott sorban szereplő módszer megfelel az adott oszlopban szereplő tulajdonságnak, $\oslash$ pedig értelemszerüen ennek ellenkezőjét. 
19. táblázat: A vizsgált tőkeallokációs módszerek tulajdonságai

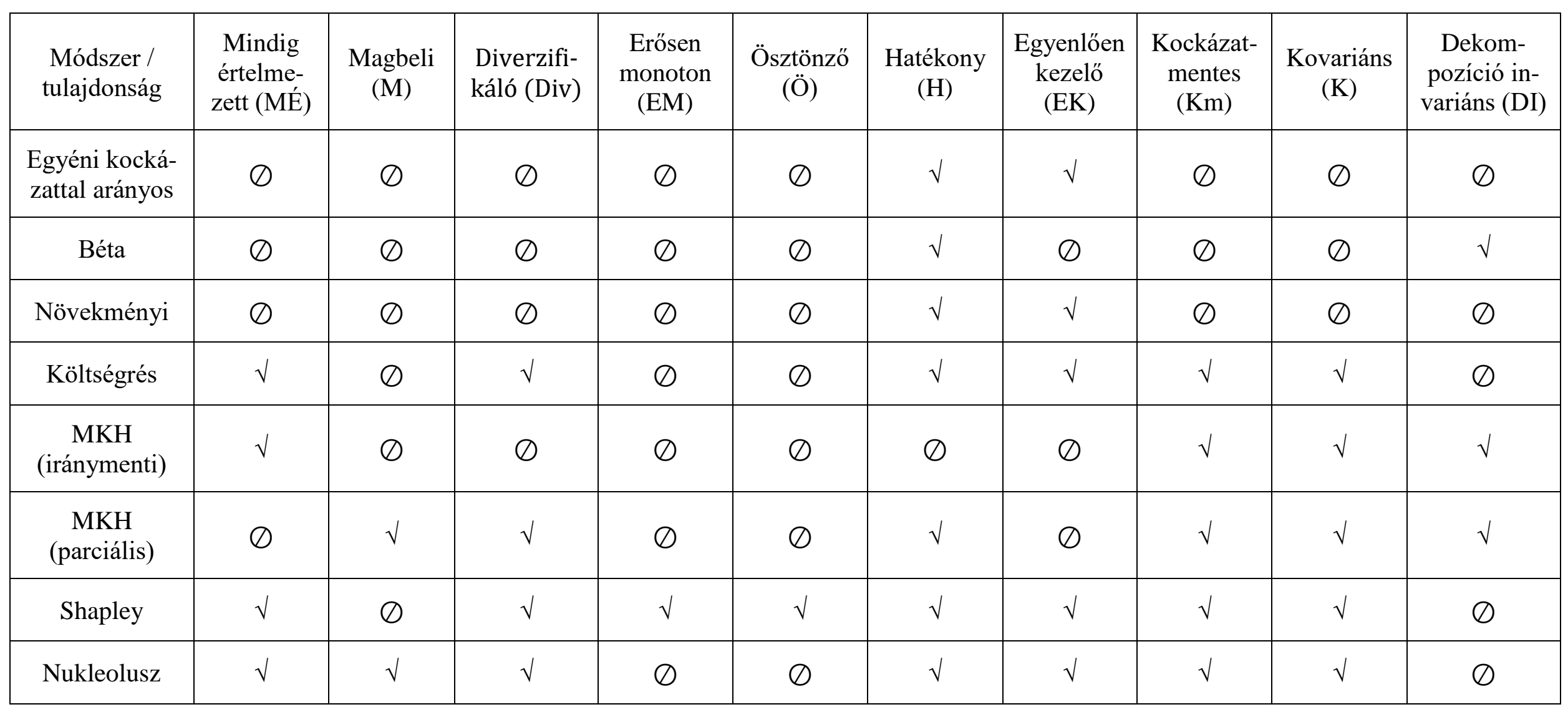


Összegezve az eredményeinket, a kooperatív játékelméletben használt módszerek (a Shapley-módszer, a nukleolusz módszer és a költségrés módszer), valamint a marginális kockázati hozzájárulás (parciális deriváltként értelmezve) felelnek meg a legtöbbnek a vizsgált tulajdonságok közül. Az elözetes várakozásoknak megfelelően a kooperatív játékelméletben használt, koalíciókon értelmezett módszerek nem teljesítik a DI kritériumot, és külön figyelmet érdemel, hogy a marginális kockázati hozzájárulás (parciális deriváltként értelmezve) nem teljesíti az Ö és EK tulajdonságokat. Szintén érdekes, hogy az Ö és EM követelményeknek kizárólag a Shapley-módszer felel meg.

Ugyanakkor a fenti tulajdonságok közül nem mindegyik teljesítése ugyanolyan fontos, sőt, vannak bizonyos tulajdonságok, melyek teljesítése nem is feltétlenül kívánatos. A módszerek alkalmazása során véleményem szerint a fentiek közül a leginkább a diverzifikáló tulajdonságnak való megfelelés a fontos (amely implikálja a hatékonyságot is). A hatékonyságot (a teljes kockázat kerüljön szétosztásra az alegységek között) számos szerző alapvető elvárásként kezeli az irodalomban, és a gyakorlatban felmerülő problémák során is a legtöbb esetben szükséges elvárás (pl. tőke allokációja üzletágakra vagy leányvállalatokra). A diverzifikáló tulajdonság pedig az elosztás igazságosságát biztosítja, s bár a magallokáció követelményénél gyengébb feltétel, de Homburg és Scherpereel (2008) valós szereplők segítségével végzett kísérlete is azt támasztotta alá, hogy a gyakorlatban (a valós gazdasági szereplők korlátozott racionalitása miatt) az elosztás „észlelt” igazságosságát jobban befolyásolja, mint a magallokáció feltételének kielégítése. Érdekes módon, önmagában csak a diverzifikáló tulajdonságot vizsgálva ismét a fent említett négy, a tízből legtöbb kritériumnak megfelelő módszer marad fenn a rostán (a Shapley-módszer, a nukleolusz módszer és a költségrés módszer, valamint a parciális deriváltként értelmezett marginális kockázati hozzájárulás). 
E négy módszert tovább elemezve azt látjuk, hogy az elosztás igazságossága szempontjából szintén igen fontos magbeliségnek két módszer (a nukleolusz és a marginális kockázati hozzájárulás) eleget tesz, míg másik kettő nem. Mint látni fogjuk, e probléma ráadásul a gyakorlatban is jelentős, nem csak elméleti. A két módszer közül a nukleolusz egyenlően kezelő, még a marginális kockázati hozzájárulás nem, a dekompozíció invariancia esetében pedig fordított a helyzet. Ez alapján a nukleolusz módszer alkalmazása javasolt, hiszen az egyforma egységek azonos kezelése meglehetősen „logikus elvárás”, a dekompozíció invariancia viszont már jóval kevésbé egyértelműen kedvező tulajdonság, hiszen az a diverzifikációhoz is szorosan kapcsolódik (hiszen pont az alegységek egymásra hatásából keletkezik a felosztandó diverzifikációs haszon, ha van ilyen).

A magbeliség mellett a másik fontos különbséget a négy legjobban teljesítő módszer között az ösztönzés, illetve az erős monotonitás jelenti, s bár az ösztönzés gyengébb követelmény, ennek is mindössze egy, a Shapley-érték felel meg (ahogyan az erős monotonitás elvárásnak is).

Ha egy módszer egy adott tulajdonságot nem teljesít, az még nem biztos, hogy problémát jelent az alkalmazás során, ha a tulajdonság megsértése csak bizonyos elméletileg lehetséges, ám a gyakorlatban nem releváns esetekben fordul elő. Ilyen például a mindig értelmezettség kérdése a parciális deriváltként értelmezett marginális kockázati hozzájárulás esetében - mint a szimulációs vizsgálatnál is látni fogjuk, ez például a gyakorlatban általában nem releváns probléma. Mivel egyrészt az MÉ, az M és Ö követelményeknek nem lehetséges egyszerre megfelelni (2.1.3. tétel), másrészt viszont mindig el lehet osztani úgy a kockázatot, hogy egyik koalícióra sem allokálunk több tőkét, mint amennyi az ő önálló tőkekövetelménye lenne, így az M követelményre fókuszálunk. Hogy tisztábban lássunk, a következő fejezetben megvizsgáljuk, hogy legfeljebb kilenc alegységet tartalmazó portfóliók esetén, véletlenszerüen generált tőkeallokációs szituációkban milyen arányban 
eredményeznek magbeli elosztást azok a módszerek, melyek az analitikus eredményeink alapján nem felelnek meg az M követelménynek. Ahogyan látni fogjuk, az, hogy egy módszer milyen arányban eredményez magbeli elosztást, nagyban függ a szimuláció során használt feltételezéseinktől - így attól is, hogy milyen problémára alkalmazzák a gyakorlatban.

\subsection{SZIMULÁCIÓS EREDMÉNYEK A MAGKOMPATIBILITÁS ELLENŐRZÉSÉRE}

Jelen fejezetben három-kilenc alegységet tartalmazó, véletlenszerüen generált tőkeallokációs szituációkat vizsgálunk olyan szempontból, hogy milyen arányban eredményeznek magbeli elosztást az egyéni kockázattal arányos, a béta, a növekményi, a költségrés és a Shapley-módszer alkalmazása esetén. A marginális kockázati hozzájárulást (iránymenti deriváltként értelmezve) nem vizsgáljuk, mivel a gyakorlatban három-kilenc véletlen szám összege soha nem lesz egyenlö, így nem várható a 2.2.16. példában szereplőhöz hasonló eset előfordulása. A kétféleképp értelmezett marginális kockázati hozzájárulás egybeesik, és a szimulált környezetben teljesítik az M feltételt.

A vizsgálat során 3-9 alegységből álló pénzügyi egységek napi hozamait (veszteségeit) szimuláltuk ${ }^{24}, 10000$ tőkeallokációs szituációt generálva, különböző verziókban. A verziók felénél minden alegység megegyező értékü, 100 millió \$ értékű kezdeti portfólióval rendelkezett. A verziók másik felében az alegységek befektetései különböző értéküek voltak, a kezdeti befektetések 10 millió \$ és 1000 millió \$ között változtak exponenciálisan, pontosabban az $i$ egység befektetésének értéke $10 \times\left(\frac{1000}{10}\right)^{i / n}$ volt.

\footnotetext{
${ }^{24}$ A használt MATLAB kódok itt elérhetők:

https://sites.google.com/site/batyitamaslaszlo/risksharing_code.zip.
} 
Minden egyes szituációban, hogy megkapjuk a profitot (veszteséget) leíró valószínűségi változót, napi hozamokat szimuláltunk, és ezek segítségével számítottuk a nominális nyereséget (veszteséget). Hogy megkapjuk a hozamokból álló idősorokat, első lépésben egy korrelációs mátrixot és az eszközök szórásait állítottuk elö. Lewandrowski et al. (2009) ún. Vine-C módszerét használtuk a korrelációs mátrixok generálásához (egyenletes eloszlású véletlen korrelációs együtthatókkal). A hozamok szórását a verziók egyik felében egyenletes eloszlással választottuk véletlenül a $(0,1)$ intervallumból (nagy szórás), a verziók másik felében pedig a $(0,0,1)$ intervallumból (kis szórás). A hozamok idősorának generálásához a verziók felében normális, a másik felében pedig Student-t eloszlást használtunk, 3 szabadságfokkal (pénzügyi alkalmazásokban ez egy tipikus érték), hogy lássuk, a hozamok eloszlásának vastagszélüsége hogyan befolyásolja az eredményeket (Cont, 2001; Mandelbrot, 1963).

1000 elemből álló hozam idősorokat generáltunk, amely hozzávetőlegesen 4 évnyi adatnak felel meg. Ha strukturális törésekkel nem kell számolnunk, akkor ez igen hosszú adatsornak tekinthetö. Mindkét esetben független, 0 várható értékü eloszlásokkal kezdtünk, és a véletlenszerüen generált korrelációs mátrixok Cholesky dekompozíciója segítségével kaptuk a többváltozós normál és Student-t eloszlásokat. Az alkalmazott kockázatmérték a 90\%-, 95\%- és a 99,9\%-Expected Shortfall volt (ez utóbbi a maximális veszteség esetünkben). Így összesen 10000 tőkeallokációs szituációt generáltunk, 3-9 alegység mellett, mindegyiket $2 \times 2 \times 2 \times 3=24$ verzióban.

A vizsgált hét módszerből a nukleolusz és a marginális kockázati hozzájárulás (parciális deriváltként) eleget tesznek M követelménynek. Ugyanakkor nem szükséges vizsgálnunk a marginális kockázati hozzájárulást iránymenti deriváltként sem, mivel annak valószínűsége 0, hogy a szimuláció során kétszer ugyanazt az értéket kapjuk egy pénzügyi egység portfóliójára. Azaz a szimuláció során soha nem jutnánk a 2.2.16. példában szereplőhöz 
hasonló esethez, a kétféleképpen értelmezett marginális kockázati hozzájárulás megegyezik és mindkettő M. Így a szimulációk során az egyéni kockázattal arányos, a béta, a növekményi, a költségrés és a Shapley-módszerrel ${ }^{25}$ kellett számolunk, minden egyes tőkeallokációs szituációban. A becsült M-arány a magbeli allokációk arányát jelenti: a vizsgált 10000 szituáció átlagaként számoltunk, ezek mindegyikének értéke 0 (nem magbeli allokáció) vagy 1 (magbeli allokáció), a standard hibát pedig bootstrap módszerrel számítottuk, 1000 ismétléssel. Az eredményül kapott standard hibák igen alacsonyak, így biztosak lehetünk abban, hogy az 10000 szimuláció elegendő az M-arány pontos becsléséhez.

A 24 verzióból 7 kiválasztottat fogunk bemutatni 3-9 alegység mellett. A normálisról vastagszélü Student-t, majd eltérő portfólió nagyságokra való áttérés eredményeit a 20. táblázat-22. táblázatok tartalmazzák. A kis szórás, illetve a maximális veszteség alkalmazásának eredményeit a 28. táblázat-30. táblázatokban mutatjuk be, a 2. mellékletben.

\footnotetext{
${ }^{25}$ A Shapley érték számításához egy publikus, a Matlab Central File Exchange webhelyen elérhető kódot használunk. A kódot Czupy Gergely (BCE) írta, 2016 június 18-i állapot szerint a következő linken elérhető: http://www.mathworks.com/matlabcentral/fileexchange/57735-shapley-value--fast-.
} 
20. táblázat: M-arányok és standard hibák azonos portfólió méret, nagy szórás, normális eloszlás és 95\%-Expected Shortfall mellett

\begin{tabular}{|c|c|c|c|c|c|}
\hline & \multicolumn{5}{|c|}{ Tőkeallokációs módszer } \\
\hline $\mathrm{N}$ & $\begin{array}{l}\text { Egyéni kock. } \\
\text { arányos }\end{array}$ & Béta & Növekményi & Költségrés & Shapley \\
\hline \multirow{2}{*}{3} & $60,65 \%$ & $25,14 \%$ & $39,64 \%$ & $100,00 \%$ & $94,68 \%$ \\
\hline & $(0,49 \%)$ & $(0,43 \%)$ & $(0,49 \%)$ & $(0,00 \%)$ & $(0,22 \%)$ \\
\hline \multirow{2}{*}{4} & $38,82 \%$ & $14,98 \%$ & $20,11 \%$ & $99,98 \%$ & $89,89 \%$ \\
\hline & $(0,51 \%)$ & $(0,37 \%)$ & $(0,40 \%)$ & $(0,01 \%)$ & $(0,30 \%)$ \\
\hline \multirow{2}{*}{5} & $24,78 \%$ & $9,34 \%$ & $9,42 \%$ & $99,67 \%$ & $86,52 \%$ \\
\hline & $(0,44 \%)$ & $(0,29 \%)$ & $(0,29 \%)$ & $(0,06 \%)$ & $(0,35 \%)$ \\
\hline \multirow{2}{*}{6} & $16,97 \%$ & $6,53 \%$ & $5,04 \%$ & $99,40 \%$ & $81,67 \%$ \\
\hline & $(0,38 \%)$ & $(0,25 \%)$ & $(0,23 \%)$ & $(0,08 \%)$ & $(0,40 \%)$ \\
\hline \multirow{2}{*}{7} & $11,26 \%$ & $3,91 \%$ & $2,25 \%$ & $99,05 \%$ & $77,22 \%$ \\
\hline & $(0,32 \%)$ & $(0,19 \%)$ & $(0,15 \%)$ & $(0,10 \%)$ & $(0,41 \%)$ \\
\hline \multirow{2}{*}{8} & $7,66 \%$ & $2,57 \%$ & $1,32 \%$ & $98,69 \%$ & $72,82 \%$ \\
\hline & $(0,27 \%)$ & $(0,16 \%)$ & $(0,12 \%)$ & $(0,11 \%)$ & $(0,46 \%)$ \\
\hline \multirow{2}{*}{9} & $5,22 \%$ & $1,84 \%$ & $0,51 \%$ & $98,86 \%$ & $68,00 \%$ \\
\hline & $(0,22 \%)$ & $(0,13 \%)$ & $(0,07 \%)$ & $(0,10 \%)$ & $(0,46 \%)$ \\
\hline
\end{tabular}


21. táblázat: M-arányok és standard hibák azonos portfólió méret, nagy szórás, t-eloszlás és 95\%-Expected Shortfall mellett

\begin{tabular}{|c|c|c|c|c|c|}
\hline & \multicolumn{5}{|c|}{ Tőkeallokációs módszer } \\
\hline $\mathrm{N}$ & $\begin{array}{c}\text { Egyéni kock. } \\
\text { Arányos }\end{array}$ & Béta & Növekményi & Költségrés & Shapley \\
\hline \multirow{2}{*}{3} & $61,34 \%$ & $14,58 \%$ & $35,48 \%$ & $100,00 \%$ & $93,48 \%$ \\
\hline & $(0,49 \%)$ & $(0,37 \%)$ & $(0,48 \%)$ & $(0,00 \%)$ & $(0,25 \%)$ \\
\hline \multirow{2}{*}{4} & $38,60 \%$ & $5,58 \%$ & $17,03 \%$ & $100,00 \%$ & $88,62 \%$ \\
\hline & $(0,47 \%)$ & $(0,23 \%)$ & $(0,36 \%)$ & $(0,00 \%)$ & $(0,32 \%)$ \\
\hline \multirow{2}{*}{5} & $25,20 \%$ & $2,17 \%$ & $8,60 \%$ & $99,53 \%$ & $83,60 \%$ \\
\hline & $(0,43 \%)$ & $(0,15 \%)$ & $(0,28 \%)$ & $(0,07 \%)$ & $(0,37 \%)$ \\
\hline \multirow{2}{*}{6} & $16,57 \%$ & $0,91 \%$ & $3,73 \%$ & $99,03 \%$ & $79,02 \%$ \\
\hline & $(0,38 \%)$ & $(0,09 \%)$ & $(0,19 \%)$ & $(0,10 \%)$ & $(0,41 \%)$ \\
\hline \multirow{2}{*}{7} & $10,54 \%$ & $0,35 \%$ & $1,92 \%$ & $98,64 \%$ & $74,88 \%$ \\
\hline & $(0,32 \%)$ & $(0,06 \%)$ & $(0,14 \%)$ & $(0,11 \%)$ & $(0,44 \%)$ \\
\hline \multirow{2}{*}{8} & $7,58 \%$ & $0,21 \%$ & $0,94 \%$ & $98,18 \%$ & $71,19 \%$ \\
\hline & $(0,27 \%)$ & $(0,05 \%)$ & $(0,09 \%)$ & $(0,13 \%)$ & $(0,43 \%)$ \\
\hline \multirow{2}{*}{9} & $4,61 \%$ & $0,07 \%$ & $0,47 \%$ & $97,91 \%$ & $67,61 \%$ \\
\hline & $(0,22 \%)$ & $(0,03 \%)$ & $(0,07 \%)$ & $(0,14 \%)$ & $(0,46 \%)$ \\
\hline
\end{tabular}


22. táblázat: M-arányok és standard hibák különbözö portfólió méret, nagy szórás, t-eloszlás és 95\%-Expected Shortfall mellett

\begin{tabular}{|c|c|c|c|c|c|}
\hline & \multicolumn{5}{|c|}{ Tőkeallokációs módszer } \\
\hline $\mathrm{N}$ & $\begin{array}{c}\text { Egyéni kock. } \\
\text { Arányos }\end{array}$ & Béta & Növekményi & Költségrés & Shapley \\
\hline \multirow{2}{*}{3} & $56,25 \%$ & $23,73 \%$ & $19,71 \%$ & $100,00 \%$ & $92,75 \%$ \\
\hline & $(0,49 \%)$ & $(0,41 \%)$ & $(0,39 \%)$ & $(0,00 \%)$ & $(0,26 \%)$ \\
\hline \multirow{2}{*}{4} & $37,96 \%$ & $11,01 \%$ & $10,48 \%$ & $100,00 \%$ & $85,52 \%$ \\
\hline & $(0,46 \%)$ & $(0,31 \%)$ & $(0,31 \%)$ & $(0,00 \%)$ & $(0,36 \%)$ \\
\hline \multirow{2}{*}{5} & $29,14 \%$ & $4,78 \%$ & $4,82 \%$ & $99,42 \%$ & $76,63 \%$ \\
\hline & $(0,47 \%)$ & $(0,21 \%)$ & $(0,22 \%)$ & $(0,08 \%)$ & $(0,44 \%)$ \\
\hline \multirow{2}{*}{6} & $22,63 \%$ & $2,31 \%$ & $2,15 \%$ & $98,20 \%$ & $67,09 \%$ \\
\hline & $(0,42 \%)$ & $(0,15 \%)$ & $(0,14 \%)$ & $(0,13 \%)$ & $(0,45 \%)$ \\
\hline \multirow{2}{*}{7} & $19,02 \%$ & $1,44 \%$ & $1,05 \%$ & $97,61 \%$ & $59,69 \%$ \\
\hline & $(0,40 \%)$ & $(0,12 \%)$ & $(0,10 \%)$ & $(0,15 \%)$ & $(0,50 \%)$ \\
\hline \multirow{2}{*}{8} & $15,36 \%$ & $0,59 \%$ & $0,43 \%$ & $96,70 \%$ & $50,30 \%$ \\
\hline & $(0,37 \%)$ & $(0,08 \%)$ & $(0,06 \%)$ & $(0,18 \%)$ & $(0,51 \%)$ \\
\hline \multirow{2}{*}{9} & $12,26 \%$ & $0,30 \%$ & $0,22 \%$ & $95,86 \%$ & $42,35 \%$ \\
\hline & $(0,34 \%)$ & $(0,06 \%)$ & $(0,05 \%)$ & $(0,20 \%)$ & $(0,48 \%)$ \\
\hline
\end{tabular}

Homburg és Scherpereel (2008) hasonló vizsgálatot végzett, de kizárólag normális eloszlás mellett és az $\alpha$-VaR (kockáztatott érték) kockázatmérték mellett, ami az nyereség/veszteség eloszlás $(1-\alpha)$ percentilisének ellentettje, ami általános esetben nem koherens kockázatmérték. A szimulációs módszerünk első tesztjeként reprodukáltuk a szerzők eredményeit (84,14\%-os szignifikancia szint mellett számított VaR-ral), és jó közelítést kaptunk, ld. a 2. mellékletben található 31. táblázatban. Az eredmények közötti kisebb eltérésnek két oka van. Egyrészt, különböző módszereket használtunk a korrelációs mátrixok generálására. Másrészt, Homburg és Scherpereel nem generált hozam idősorokat, hanem 
analitikus számították ki a kockázatot, a portfólió értékek kovariancia mátrixa alapján. Ezt vagy a mögöttes eloszlás ismereteként, vagy végtelenül hosszú idősorok alkalmazásaként értelmezhetjük. Mi ezzel szemben a realizációs vektorok használatával és korlátos hosszúságú idősorok alkalmazásával kis zajt hoztunk a rendszerbe, ami a pénzügyi piacok fontos velejárója (ld. pl. Kondor et al., 2007). Homburg és Scherpereel (2008) munkájával összevetve szintén különbség, hogy mi az eltérő portfóliónagyságok, a kisebb és nagyobb szórás, valamint vastagszélü eloszlás alkalmazásának a hatását is vizsgáltuk. A normális eloszlású esetben az Expected Shortfall kockázatmérték alkalmazásának nincsen hozzáadott értéke a VaR-hoz képest, hiszen közismert, hogy az csak konstans-szorosa a VaR-nak, és ebben az esetben a VaR is koherens. Ugyanakkor vastagszélü eloszlás alkalmazása mellett az Expected Shortfall jobb, mint a VaR, hiszen az a VaR-t meghaladó veszteségeket is figyelembe veszi. Ennek eredményeképp a szimulációnkban, szemben Homburg és Scherpereel (2008) eredményeivel, a béta módszer nem mindig eredményez magbeli elosztást, az M-aránya akár 1\% alatti is lehet (ld. 20. táblázat).

Az egyes verziók összehasonlítása során, amikor csak egy-egy paramétert változtattunk, a következő eredményeket kaptuk. Általánosságban elmondható, hogy minden allokációs módszer esetében az M-arány csökken az alegységek számának növelésével, valamint az Expected Shortfall számítása során alkalmazott szignifikancia szint $(\alpha)$ növelésével.

Az azonos értékű portfóliókról különböző értéküekre való áttérés általában csökkentette az M-arányt az egyéni kockázattal arányos, a növekményi, a költségrés és a Shapley-módszer esetében; a béta módszernél viszont csökkenésre és növekedésre is láttunk példát.

Kicsiröl nagy szórásra való áttérés eredményeképp az M-arány általában nőtt az egyéni kockázattal arányos és a költségrés módszernél, miközben a többi módszer esetében csökkent. 
A vastagszélü, Student-t eloszlásra való váltás hatására a béta módszernél csökkent az Marány, még a többi módszer esetében a változás iránya a szimuláció egyéb paramétereinek függvényében változott.

Minden vizsgált verzióban a legmagasabb M-arányt a költségrés módszer esetében kaptuk, ami azzal magyarázható, hogy a költségréseken keresztül a módszer figyelembe veszi az egyes alegységek alkupozícióját. Általában az egyéni kockázattal arányos módszer jobban teljesített a növekményi módszernél, de a 2. mellékletben található 29. táblázatban ellenpéldát is találunk. Ugyanakkor egyik szimulációs verzióról a másikra való áttérés, vagy akár csak az alegységek számának megváltoztatása is könnyen módosítja az egyes módszerek közötti sorrendet.

A gyakorlatban való alkalmazásra vonatkozó következtetésünk, hogy a vizsgált módszerek közül a költségrés módszer teljesít legjobban, de ennek az M-aránya is lemehet akár 30\% alá. A többi vizsgált módszer közötti választáshoz érdemes figyelembe venni, hogy az alkalmazás leginkább melyik szimulációs verziónak felel meg, és az alapján választani.

\subsection{KÖVETKEZTETÉSEK}

Csóka és Pintér (2016) megmutatták, hogy koherens kockázatmérték alkalmazása mellett nincs olyan tőkeallokációs módszer, amely eleget tesz az MÉ, M és Ö tulajdonságoknak. Meg kell jegyeznünk, hogy a szerzők általános koherens kockázatmértékre bizonyítják az állítást, de az eredményük érvényes bármekkora százalék mellett számított Expected Shortfall esetén, kivéve a 0\%-ot (amely az átlagos vesztséget (nyereséget) jelenti). Példának okáért az ellenpéldák, melyeket hozunk, ugyanígy müködnének 1\%-Expected Shortfall mellett is, ha a legrosszabb kimenetel valószínüségét 99\%-ra változtatnánk, és ugyanez a

logika alkalmazható Csóka és Pintér (2016) bizonyítására is. A 0\%-Expected Shortfall 
alkalmazása esetén nincsen diverzifikációs hatás a várható érték additív tulajdonsága miatt, és a Shapley-módszer (és számos másik módszer is) kielégíti az MÉ, M, Ö feltételeket, az egyes alegységekre az általuk elszenvedett átlagos veszteséget allokálva. A gyakorlati alkalmazások túlnyomó többségében az Expected Shortfall esetében alkalmazott szignifikancia szint jóval magasabb, mint 0\%, jellemzően $90 \%$ feletti.

A koherens kockázatmértékek osztályán, melyen az MÉ, M és Ö kritériumok összeegyeztethetetlenek, hét módszert elemeztünk (egyéni kockázattal arányos; béta; növekményi; költségrés módszer; marginális kockázati hozzájárulás parciális, illetve iránymenti deriváltként értelmezve; továbbá a Shapley- és nukleolusz módszerek) tíz lehetséges tulajdonság szempontjából (mindig értelmezettség, magbeliség, diverzifikáció, erős monotonitás, ösztönzés, hatékonyság, egyenlően kezelés, kockázatmentes allokáció, kovariancia, dekompozíció invariancia). A 19. táblázat és a mögöttes állítások hasznos útmutatóként szolgálhatnak a gyakorlati alkalmazóknak, amikor módszert választanak, vagy egy-egy kiválasztott módszer kapcsán potenciálisan felmerülő problémákra szeretnének felkészülni.

Szintén megvizsgáltuk, hogy véletlenszerüen generált tőkeallokációs szituációk esetében milyen arányban eredményez magbeli allokációt az egyéni kockázattal arányos, a béta, a növekményi, a költségrés és a Shapley-módszer legfeljebb 9 alegység esetén, 24 különböző verzióban. Megmutattuk, hogy a vizsgált módszerek közül a költségrés módszer teljesít legjobban, általában 90\% feletti arányban magbeli elosztást eredményezve, bár az arány akár $30 \%$ alá is csökkenhet. Általánosságban elmondható, hogy az egyes módszerek M aránya erősen függ a vizsgált verziótól, de az alegységek számának növelésével mindig csökken. Mint említettük, bár az elosztás igazságosságát elméletben a magallokáció követelményének való megfelelés biztosítja, de a gyakorlatban az elosztás észlelt igazságosságához a diverzifikáció követelménye is elegendő, ezért következő lépésben érdemes lenne ezt is 
hasonló vizsgálatnak alávetni. Szintén hasznos lenne további kutatási kérdésként hasonló vizsgálatot végezni a kockázatmentes allokáció, kovariancia és dekompozíció invariancia tulajdonságok kapcsán, komoly kihívás az ösztönzés, az erős monotonitás és az egyenlően kezelés tulajdonságok esetében; a mindig értelmezettség és a hatékonyság kritériumok esetében viszont nem szükséges.

A pénzügyi idősorok jellemzően zajosak, amit realizációs vektorokat szimulálásával modelleztünk. Kiderült, hogy a realizációs vektorok alkalmazásának előnye (akár historikus szimulációval, akár az elméleti eloszlásból történő mintagenerálással), hogy a marginális hozzájárulás mindkét definíció szerint értelmezett és teljesíti az M feltételt.

Mivel Csóka és Pintér (2016) megmutatta, hogy egyedül a Shapley-módszer teljesíti az MÉ, EK, EM (így Ö) és H tulajdonságokat, különös figyelmet érdemel, hogy az M kritériumot viszont nem teljesíti. A szimulációs vizsgálatunk megmutatta, hogy a Shapley-módszer minden verzióban az esetek szignifikáns részében a magon kívüli elosztást eredményez. Így a Csóka és Pintér (2016) által azonosított probléma nem csak elméletben, hanem a gyakorlatban is jelentőséggel bír. 


\section{RÉSZ: A TŐKEALLOKÁCIÓ GYAKORLATI ALKALMAZÁSA}

A disszertáció előző része hét lehetséges, a tőkeallokációs probléma megoldása során alkalmazható módszert, és ezek legfontosabb tulajdonságait elemezte részletesen. Ahogyan a bevezetőben is említettem, a tőkeallokáció elméletével foglalkozó irodalom rendkívül széleskörü, azonban - hasonlóan jelen disszertáció 2. részéhez - leginkább elméleti jellegü, a módszertani kérdésekre koncentrál. Számos szerző vizsgálja a kérdést az itt is alkalmazott játékelméleti megközelítésben (pl. Denault, 2001; Csóka et al., 2009, Csóka és Pintér, 2016), de szintén jellemző az opcióárazási (pl. Myers és Read, 2001; Sherris, 2006; Kim és Hardy, 2007) és egyéb statisztikai megközelítés is (pl. Kalkbrener, 2005; Homburg és Scherpereel, 2008; Buch és Dorfleitner, 2008). A gyakorlati alkalmazás kérdéseiről ezzel szemben jóval kevesebb szó esik, ahogyan Kim és Hardy (2007, p23) írja, ,, a tőkeallokációs módszerek nagyobb részt axiómák alapján kerültek kialakitásra, nem pedig [a felhasználás $\left.{ }^{26}\right]$ céljai szerint, és kevés kutatási eredmény áll rendelkezésre a célok fényében történő alkalmazásra vonatkozóan”. Hasonló véleményt fogalmaz meg Meyers (2005, p26) is: „Sajnos kiderült, hogy a gazdasági allokáció nem ekvivalens az axiomatikus allokációval”. Tanulmányom jelen részének célkitüzése ezt a rést csökkenteni: a témában olyan áttekintést nyújtani, amely gyakorlati oldalról közelíti meg a tőkeallokáció kérdését. Ugyanakkor erősen támaszkodom majd az előző részre is, jelölésekben is mindenhol a 2.1. fejezetben definiáltakat fogom követni. Mivel szofisztikált tőkeallokációs módszertanok alkalmazása leginkább a biztosítók körében jellemző, a vizsgálat során erre az iparágra fókuszálok. (Ugyanakkor a következőkben tárgyaltak nagy része analóg módon alkalmazható lenne a bankszektorban is.)

\footnotetext{
${ }^{26}$ A fordító kiegészítése
} 
A tanulmány jelen részének további felépítése a következö. A 3.1. fejezetben mutatom be a lehetséges alkalmazásokat, azaz, hogy miért fontos, mire használják a biztosítótársaságok a tőkeallokációt. A 3.2. fejezetben, az 1. részben definiált fogalmakra támaszkodva azt vizsgálom, hogy mit, milyen típusú tőkét osztunk szét a tőkeallokáció során. A további fejezetekben a lehetséges alkalmazások fényében mutatom be a tökeallokáció gyakorlati alkalmazásának egy-egy aspektusát, illetve teszek javaslatokat annak implementációjára vonatkozóan. A 3.3. fejezetben a mire kérdéssel foglalkozom: milyen egységek között osztjuk fel a tőkét - hiszen az egyes üzletágak mellett akár termékenként, termékcsoportonként, vagy leányvállalatonként is allokálhatjuk azt. A 3.4. fejezetben arra keresem a választ, hogy hogyan történjen a szétosztás: a különböző alkalmazható módszerekkel, illetve az ezektől elvárható tulajdonságokkal foglalkozom. A 3.5. fejezetben összefoglalom a legfontosabb eredményeket.

\subsection{MIÉRT - A TŐKEALLOKÁCIÓ KÜLÖNBÖZÖ ALKALMAZÁSAI}

A tőkeallokációnak számos különböző felhasználási területe létezik, használják bankokban (pl. Balogh, 2006; Homburg és Scherpereel, 2008), alapkezelőknél, biztosítóknál (pl. Butsic, 1999, Albrecht, 2006; De Angelis és Granito, 2015) továbbá a tőke helyett költségallokációként értelmezve számos egyéb, nem pénzügyi területen is. A fent említetteknek megfelelően a következőkben csak a biztosítási szektorra koncentrálok, azonban itt is többféle alkalmazással találkozhatunk, melyeket az alábbiakban mutatok be.

\subsubsection{TELJESÍTMÉNYÉRTÉKELÉS}

A teljesítményértékelés kétségkívül a tőkeallokáció legfontosabb és legelterjedtebb alkalmazási területe. Ilyenkor üzletágak (vagy pl. leányvállalatok) teljesítményének 
értékelése során azok elért teljesítményét (hozamát) az általa lekötött tőkéhez viszonyítva mérjük. Ez hasonlóan jellemzően a bankokra is, ugyanakkor a biztosítók üzletágai a bankokhoz képest sokkal inkább homogének, összemérhetők, így a teljesítményük egymáshoz való hasonlításának is nagyobb a relevanciája. A kockázattal korrigált teljesítmény értékelésére a leggyakrabban alkalmazott mutató a RORAC (Return On Risk Adjusted Capital), melyet Tasche (2008)-at követve a következőképp adható meg a teljes biztosítóra vonatkozóan:

$$
\operatorname{RORAC}(X)=\frac{E\left(X_{N}\right)}{\rho\left(X_{N}\right)}=\frac{\sum_{i=1}^{n} E\left(X_{i}\right)}{\rho\left(X_{N}\right)}
$$

ahol a 2.1. fejezet jelöléseit használva $X_{1}, \ldots, X_{n}$ valós értékü valószínüségi változók az egyes üzletágak nyereségei (veszteségei), $\sum_{i=1}^{n} X_{i}=X_{N}$ a teljes biztosító nyeresége/vesztesége; $\rho\left(X_{N}\right)$ pedig a biztosító $\rho$ kockázatmértékkel mért tőkeigénye. Az egyes üzletágak RORAC mutatója pedig:

$$
\operatorname{RORAC}\left(X_{i} \mid X\right)=\frac{E\left(X_{i}\right)}{\varphi_{i}\left(X_{N}^{\rho}\right)}
$$

ahol $\varphi_{i}\left(X_{N}^{\rho}\right)$ az $i$ üzletágra allokált tőkét jelöli. Bár jelen tanulmány fő témája a fenti kifejezés nevezője, meg kell jegyezni, hogy nagyon fontos körültekintően eljárni a nevező mellett a számláló tartalmának meghatározásakor is. Az első fontos kérdés, hogy a RORAC mutatót ex ante, vagy ex post alkalmazzunk. Az elöbbi eset stratégiai döntések (pl. nagyobb tranzakciók hatásának elemzése) kapcsán jellemző, míg a teljesítményértékelés kapcsán általában ex post használjuk, azaz a számlálóban várható érték helyett a ténylegesen realizált hozam szerepel (ahogyan később az esettanulmányban mi is alkalmazzuk majd, ld. az 4. részben). A RORAC számításakor a biztosítók általában a nettó jövedelmet veszik figyelembe, az adók és veszteségleírások után (Cummins, 2000). Ahogy később még visszatérek rá, fontos kérdés továbbá, hogy hogyan kerül figyelembe vételre a különböző 
termékek által generált befektethető forrásokon elért hozam. A biztosítók általános gyakorlata e tekintetben, hogy az egyes üzletágak tényleges eredményéhez hozzáadják az általuk generált forrásokkal elérhető kockázatmentes hozamot, a befektetési üzletág értékeléskor pedig csak az ezt meghaladó összeget veszik figyelembe. Egy amerikai biztosítónál müködő teljesítményértékelési és tőkeallokációs modellt mutat be például Bingham (2014).

Az üzletágak mellett elképzelhető még leányvállalatok, egyes üzletágakon belül termékportfóliók, egyes termékek teljesítményének értékelése is (ld. a 3.3. fejezetben). Továbbá az allokációs módszerek elméletben a javadalmazás, egyéni teljesítményértékelés során is alkalmazhatóak, azonban a gyakorlatban ez jóval kevésbé jellemző.

\subsubsection{STRATÉGIAI DÖNTÉSEK}

A tőkeallokációs módszerek stratégiai döntések során való alkalmazása igen fejlett vállalati kockázatkezelési gyakorlatot feltételez. A tőkeallokációs technikák tervezett felvásárlások és összeolvadások értékelése, valamint új üzletágak indításáról és meglévő üzletágak megszüntetéséről való döntések során is alkalmazhatóak.

Egy-egy tranzakció előzetes elemzésének igen fontos eleme a tőkeszükséglet változásának felmérése (ld. pl. Mueller, 2004). A tőkeallokáció segítségével nem csak a teljes biztosító szintjén jelentkező tőkeigény változást tudjuk megbecsülni, de azt is, hogy hogyan változik egy-egy meglévő üzletág hozzájárulása a biztosító teljes kockázatához. Ez igen fontos információ, hiszen akár jelentős változás is bekövetkezhet az üzletágak mért jövedelmezőségében.

A kockázattal korrigált eredmény (ld. az előző alfejezetben) igen fontos input a stratégiai tervezés során is, hiszen ez alapján dönthető el, hogy melyik üzletág fejlesztése növeli 
legnagyobb mértékben a vállalat értékét, s melyiket érdemes inkább leépíteni (ld. pl. Venter, 2004). Amikor a tőkeallokáció célja a stratégiai döntések támogatása, az alkalmazott módszertan nagyon hasonló a teljesítményértékeléshez, azonban nem múltbeli, hanem várható jövedelmezőségi és kockázati mutatók felhasználásával történik az értékelés.

\subsection{3 ÁrAZÁS}

A harmadik fontos felhasználási terület biztosítók esetében az árazás. Venter (2009) szerint a biztosítási szakma képviselői az egyéb pénzügyi intézmények képviselőivel szemben kisebb mértékben fogadják el a hagyományos (CAPM, arbitrázsmentes árazás) árazási modelleket, elsősorban az életbiztosítási üzletágra jellemző vastagszélü veszteségeloszlás miatt, amely az első és második momentumok segítségével nem modellezhető megfelelően. Ennek következtében a biztosítók körében felmerül az igény a tőkeallokációs módszereken alapuló árazási modellekre. A Mueller et al. (2004) által a Society of Actuaries ${ }^{27}$ égisze alatt készített gazdasági tőkéről szóló felmérés is azt mutatta, hogy a biztosítók nagy arányban használják fel az allokált gazdasági tőkét a termékárazás során. Általános megközelítésben egy biztosítási termék ára (a prémium) a következő tényezőkből adódik (Werner és Modlin, 2016, p5):

Prémium = Szerzödésekböl származó követelések + Kifizetésekhez kapcsolódó költségek +

$$
\text { Szerzési költségek + Profit }
$$

A fenti felírásban a profitnak optimális esetben fedeznie kell a tőkétől elvárt hozamot is: minél nagyobb a tőkeigénye egy adott terméknek, annál nagyobb profitot várunk el tőle. Az egyes termékek tőkeigénye pedig ismét a tőkeallokációs módszerek segítségével határozható

${ }^{27}$ Aktuárisok Szövetsége 
meg. Bár elméletben lehetséges lenne közvetlenül a termékekre is tőkét allokálni, de a gyakorlatban ez sokszor túlságosan is bonyolult, s a szükséges adatok sem állnak rendelkezésre termék szinten. Emiatt a biztosítók egy-egy termék tőkeköltségének meghatározásakor az adott üzletágra allokált tőkét osztják a termékekre valamilyen lineáris közelítés segítségével. Az egyes termékek árában szereplő profit tényező tehát $(H R-r) *$ $\varphi_{i}\left(X_{N}^{\rho}\right)$-ként írható fel, ahol $H R$ a tőke elvárt hozama (,hurdle rate”), $r$ a kockázatmentes hozam (a tökét biztosító eszközökön elért hozam), $\varphi_{i}\left(X_{N}^{\rho}\right)$ pedig jelen esetben az adott termékre allokált tőkét jelenti.

Az árazással kapcsolatban megjegyzendő azonban, hogy nincs egyetértés arra vonatkozóan, hogy a tőke költségét be kell-e ilyen módon építeni a termékek árába. Más megközelítésben ugyanis a tőkének nem lehet szerepe az árazásban, melynek csak a biztosított kockázat eloszlásán kell alapulnia. Ezen érvelés szerint a biztosítókra vonatkozó szigorú tőkeszabályozásnak köszönhetően már nincsen addicionális hozzáadott értéke az elvártnál magasabb tőke tartásának, a biztosítottak nem fizetnek többet ugyanazért a biztosításért a biztosítást nyújtó tőkeellátottságától függően. (Ez azonban nem jelenti, hogy nincs szükség a tőkeallokációs módszerekre, hiszen attól függetlenül, hogy nem az árazásban használják, az üzletágak teljesítményének értékelése során az allokált tőke meghatározására továbbra is szükség van: a vezetőség számára a legfontosabb információ a befektetett tőkén elért megtérülés.)

\subsection{MILYEN TÍPUSÚ TŐKÉT ALLOKÁLUNK?}

A tőkeallokációhoz vezető út első lépéseként fontos tisztázni, hogy pontosan mi is az, amit valójában allokálni szeretnénk, vagyis mit nevezünk a biztosító tőkéjének. Bár a kérdés triviálisnak tűnhet, valójában rengeteg tőkefogalommal találkozunk akár az irodalomban, 
akár egy-egy biztosító mérlegét tanulmányozva (szabályozói tőkekövetelmény, gazdasági tőkeszükséglet, különböző számviteli kategóriák). A tőkeallokációval foglalkozó tanulmányok nagy része jelentős egyszerüsítéssel kezeli a tőke meghatározásának kérdését (ami persze érthető, hiszen a módszerek számos problémára alkalmazhatóak, melyeknél más és más jelenti az allokálandó tőkét vagy kockázatot; akár csak egy bank és egy biztosító esetében is más a terminológia és a tartalom is).

\subsubsection{TŐKEFOGALMAK - ISMÉTLÉS}

A tanulmány 1.2. fejezetében részletesen foglalkoztam a különböző tökefogalmakkal, az alábbiakban röviden felidézem ezeket.

A rendelkezésre álló tőke (vagy fizikai tőke) számviteli kategória, amely a biztosító mérlegéből olvasható ki, kis egyszerüsítéssel az eszközök és kötelezettségek különbsége.

A tőkekövetelmény ezzel szemben valamilyen kockázatmérési módszerrel számszerüsített, elvárt tőkeigény. Két osztályra bonthatjuk: szabályozói tőkekövetelményre és gazdasági tőkeigényre.

Szabályozói tőkeszükséglet alatt a szabályozó által előírt kötelező minimum tőkekövetelményt értjük, Európában a Szolvencia II követelményei az irányadók. A Szolvencia II szabályozás értelmében a tőkeszámítás során a biztosítók választhatnak, hogy standard módszert, részleges vagy teljes belső modellt alkalmazásnak. Maga a Szolvencia II tőkekövetelmény (SCR) akár belső modellel, akár a standard módszerrel kerül kiszámításra, 99,5\%-os szignifikancia szint és egy éves időhorizont mellett számított kockázatott értéknek felel meg (ld. 1.1.3.2. fejezet).

Gazdasági tőkeigény alatt a társaság belső kockázatértékelése alapján számított tőkeszükségletet értjük. Gazdasági tőkeszükséglet a fenti második pilléres belső 
tőkeszámítás eredményeként előálló tőkeigény, de gazdasági tőkeszükséglet számítást egyéb belső célokra a biztosítók a Szolvencia II elöírásaitól teljesen függetlenül is végez(het)nek. A gazdasági tőkeszükséglet számítás célja, hogy a lehető legpontosabban kerüljenek felmérésre a biztosító tevékenysége során felmerülő kockázatok. A gyakorlatban a gazdasági tőkeszükséglet az, amelyet valamely kiválasztott kockázatmérték segítségével számszerüsítünk.

\subsubsection{TÖKEFOGALMAK MEGFELELTETÉSE}

A 2. részben tárgyalt, illetve a szakirodalomban elérhető egyéb módszerek alkalmazásához első lépésben meg kell feleltetnünk egymásnak az elméletben, illetve a gyakorlatban használt tőkefogalmakat. A tőkeallokáció módszertani kérdéseivel foglalkozó tanulmányok többsége a 2.1. fejezetben felírt, vagy ahhoz hasonló problémaként tekint a kérdésre, azaz a tőkét valamilyen kockázatmérték segítségével számszerüsített kockázatként $(\rho(X))$ értelmezi. Így tesz többek között Kalkbrener (2005), Tasche (2008), Dhaene et al. (2012), Assa (2016), ahogyan jelen disszertáció 2. része is ezzel a megközelítéssel dolgozik. E felfogásban $\rho(X)$ az elvárt tőke fogalmának felel meg, hiszen a társaság kockázatainak értékelése alapján ennyi tőke kell(ene), hogy rendelkezésre álljon. Már itt jól látszik, hogy az alkalmazott terminológia távolról sem standard, ugyanis az irodalomban jellemző (pl. Tasche, 2008) az ilyen módon definiált tőkére gazdasági tőkeként hivatkozni. Ennek oka, hogy korábban valójában csak a gazdasági tőke felelt meg a $\rho(X)$ felírásnak, ez tükrözte leginkább a szóban forgó portfólió tényleges, mérhető kockázatait, a szabályozás jelentős fejlődésének eredményeképp azonban mára már a szabályozói - legalábbis a Szolvencia II értelmezésében - tőkekövetelmény is e szemléletben meghatározott. 
Más megközelítést alkalmaznak az opcióárazással dolgozó tanulmányok (Myers és Read, 2001; Sherris, 2006; Kim és Hardy, 2007), melyek tőkének az eszközök értékének és a várható kárigény jelenértékének különbségét tekintik, a következő sematikus mérleg szerint.

4. ábra: A biztositó sematikus mérlege

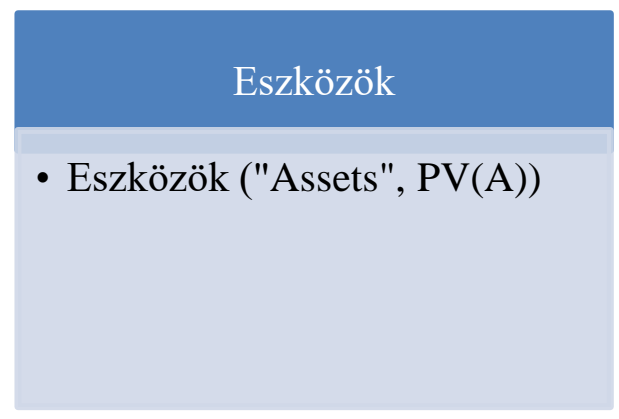

\section{Források}

• Többlettőke ("Surplus", S)

- Kárigény jelenértéke $(\mathrm{PV}(\mathrm{L}))$

Ebben a megközelítésben gyakori a „surplus” elnevezés használata, melyet talán leginkább többlettőkének érdemes fordítani. A többlettőke értéke a mérlegazonosság alapján határozódik meg: $S=P V(A)-P V(L)$, ahol $P V(A)$ az eszközök, $P V(L)$ pedig a várható kárigény jelenértéke. Ezzel a felírással kapcsolatban fontos azonban észben tartani a következőt: a bal oldalon az eszközök piaci értéken szerepelnek, azaz PV(A) már figyelembe veszi a biztosító csődjének lehetőségét, míg PV(L) ezzel nem kalkulál. A biztosító ugyanis a korlátozott felelőssége miatt tulajdonképpen egy put opcióval rendelkezik, melyet az irodalom csődopciónak (default option ${ }^{28}$; D) nevez. Amennyiben a vállalat kötelezettségeinek értéke a figyelembe vett periódus végén meghaladja eszközeinek értékét ( $L>A)$, abban az esetben is csak A-t kell kifizetnie, az opció értéke tehát $D=$ $P V(\max (0 ; L-A))$. A saját tőke (,equity”; E) értéke a modellben úgy adódik, ha a kötelezettségek értékelésében is figyelembe vesszük a csődopció értékét, azaz

$$
E=P V(A)-(P V(L)-D)=S+D
$$

\footnotetext{
${ }^{28}$ Gyakori a „solvency exchange option” elnevezés használata is.
} 
A fenti többlettőke fogalom (S) tehát egy bemeneti változó a saját tőke („equity”, E) kiszámításához. ${ }^{29}$

Fontos észrevennünk, hogy ebben az értelmezésben használt többlettőke („surplus”) fogalom nem azonos a Szolvencia II Irányelv által definiált többlettőkével (ld. 2. ábra). Az ábrára visszatekintve a kötelezettségek piaci értéke, amely Myers és Read (2001) értelmezésében $P V(L)-D$, az ábrán a biztosítástechnikai tartaléknak (legjobb becslés + kockázati ráhagyás) felel meg. A saját tőke (E) értéke pedig az ábrán szereplő SCR és a többlettőke összege. A fenti, Myers és Read (2001) szerinti megközelítéssel az a gond, hogy ilyen értelmezésben a tőke gyakorlatilag csak egy mérlegazonosságból származtatott, könyvelési kategória, melynek önmagában kevés köze van a társaság kockázati profiljához.

\subsubsection{KERÜLJÖN SZÉTOSZTÁSRA?}

A tőkeallokációval kapcsolatban ez az egyetlen kérdés, amelyre (szinte) általános érvényü válasz adható: mindig gazdasági tökeszükségletet javasolt allokálni. Ahogy Vrieze és Brehm (2003) is megjegyzi Myers és Read (2001) modelljének gyakorlati implementálási lehetőségéről szóló elemzésükben: a gazdasági tőkeszükséglet jellemzi az adott intézmény tényleges kockázati profilját megfelelő, így az allokációt is értelemszerüen ezen célszerü vizsgálni - konzisztensen azokkal a szerzőkkel, akik az allokálandó tőkét $\rho(X)$-ként definiálják.

A biztosítók a teljesítményértékelés során sokáig a szabályozói tőkekövetelményt vették alapul, azonban egyre inkább terjed a gazdasági tőkeszükséglet használata (Mueller et al., 2004). Ez - a mellett, hogy a gazdasági tőkeszükséglet pontosabb képet ad a cégek által

\footnotetext{
${ }^{29}$ Butsic (1994) egyáltalán nem is tesz különséget a Myers és Read (2001) által használt többlettőke és a biztosító tőkéje között.
} 
vállalt tényleges kockázatokról, mint a szabályozói ${ }^{30}$ - azért is praktikus, mert a több országban is jelen lévő biztosítóknál probléma, hogy az egyes országokban jelentősen eltérhet a szabályozói tőkekövetelmény, melyeket ilyen módon összevetni sem ésszerü. A teljesítményértékelés során történő felhasználásra koncentrálva az alkalmazni javasolt tőke típusokról, s az elvégzendő korrekciókról részletes útmutatót ad Albrecht ${ }^{31}$ (2006). Szintén a kockázatok pontosabb értékelése, és a szabályozói tőkekövetelmény esetleges országonkénti eltérései miatt mind az árazás, mind az egyéni teljesítményértékelés során érdemesebb inkább a gazdasági, mint a szabályozói tőkekövetelményt alapul venni.

\subsection{MILYEN EGYSÉGEKRE IRÁNYUL A TŐKE SZÉTOSZTÁSA?}

A 2.1. fejezetben a tőkeallokációs probléma felírása során az egyszerüség kedvéért üzletágaknak neveztem a biztosító alegységeit, melyekre a tőke felosztásra kerül. Ugyanakkor az allokáció más egységekre is irányulhat: találkozhatunk még a kockázat leányvállalatokra, termékekre vagy termékcsoportokra, különböző földrajzi régiókra, vagy akár értékesítési csatornákra történő szétosztásával is - természetesen mindig az allokáció céljával összhangban.

A gyakorlatban a legjellemzőbb alkalmazás, hogy a biztosítók tőkéjüket az egyes üzletágaik között allokálják. Az üzletágak felosztása országonként, biztosítónként más és más lehet. A Szolvencia II irányelv az alábbi csoportosítást alkalmazza:

- életbiztosítás ${ }^{32}$;

\footnotetext{
${ }^{30}$ Kivéve ha a kettő egybeesik.

${ }^{31}$ Albrecht (2006) a szabályozó tőkekövetelményt külső kockázat alapú tőkének nevezi, a cég-specifikus, belső modell alapján számolt tőkekövetelményt pedig virtuális kockázat alapú tőkekövetelménynek (,,virtual risk based capital"); a teljesítményértékelés során a kockázat alapú tőkekövetelmény módosított verzióját, a kockázattal korrigált tőkét javasolja alkalmazni.

${ }^{32}$ Részletesebb bontás az irányelv II. mellékletében található.
} 
- egészségbiztosítás;

- nem-élet biztosítás, ezen belül (az irányelv V. melléklete alapján) ${ }^{33}$ :

○ baleset- és betegségbiztosítás;

○ gépjármü biztosítás;

○ tüz- és egyéb vagyoni kár;

- légi, tengeri és fuvarozási biztosítás;

○ általános felelősségbiztosítás;

○ hitel- és kezesség biztosítás;

○ egyéb ágazatok.

Az üzletágak meghatározása elsőre szintén triviális gyakorlatnak tünhet, azonban a tőkeallokáció során van egy igen fontos kérdés, amelyet az alkalmazónak kezelnie kell: mi történjen a biztosító eszköz oldali kockázataival, azaz a fentiekben nem szereplő befektetési divízió által generált kockázatokkal? A biztosítási üzlet jellegéből adódóan (biztosítási díjak beszedése, majd a keletkező károk kifizetése egy későbbi időpontban) ugyanis a biztosítóknál jelentős mennyiségű befektethető forrás keletkezik, s el kell döntenünk, hogy mi történjen a befektetésből származó kockázatokkal. Két lehetséges választ adhatunk: vagy eszközarányosan elosztjuk az egyes üzletágak között (tehát pl. az életbiztosítások díjából keletkező befektethető állomány kockázatát az életbiztosítási üzletág kockázataként kezeljük), vagy a befektetési divíziót külön üzletágnak tekintjük az allokáció során. A két megközelítés közül az alapján érdemes választani, hogy mi a tőkeallokáció célja. Amennyiben teljesítményértékelés, akkor logikus, hogy elkülönítve kezeljük a befektetéseket, a következők miatt. A biztosítási kockázatok vállalása, valamint a befektetési döntések az esetek túlnyomó többségében teljesen elkülönítetten születnek, a biztosítók

\footnotetext{
${ }^{33}$ Részletesebb bontás az irányelv I. mellékletében található.
} 
általános gyakorlata szerint a két tevékenységet külön kezelik. Ugyanakkor tény, hogy a befektethető források a biztosítások értékesítése során keletkeznek, emiatt az egyes üzletágak teljesítményének értékeléskor implicit módon azt feltételezi a biztosító, hogy azokat az üzletágak kockázatmentes befektetésekbe fektetik, a várható jövőbeli cash flowjához igazított lejárati szerkezetben (ez történne, ha nem lenne külön befektetési üzletág a biztosítóban). A befektetések nyereségét pedig úgy számolják el, hogy csak a kockázatmentes hozamon felül elért nyereséget (veszteséget) írják a befektetési üzletág „számlájára”. Alap esetben tehát az egyes üzletágtól külön kezelendő a befektetési tevékenység, kivételt jelenthet azonban az árazás. Ha ugyanis a befektetések nyereségét a biztosítási termékeknél számoljuk el, az az árazás során a termék árának csökkentésével ekvivalens - ezt erősen kompetitív piac esetén a biztosítók gyakran meg is teszik.

A termékcsoportok, illetve termékek szerinti felosztás az üzletágankénti felosztással analóg, csak a szegmentáció részletesebb, e felosztásoknak elsősorban a termékárazásban lehet relevanciája. Az allokáció továbbá irányulhat még leányvállalatokra, különböző értékesitési csatornákra, vagy földrajzi régiókra.

\subsection{AZ ALLOKÁCIÓS MÓDSZER KIVÁLASZTÁSA}

A tőkeallokációval kapcsolatosan talán a legfontosabb kérdés a megfelelő allokációs módszer kiválasztása. A szakirodalomban számos eltérő tulajdonsággal bíró módszer található, az alkalmazók számára pedig komoly fejtörést okozhat a különböző fogalmi keretekben definiált módszerek és kritériumok közötti eligazodás. A feladatot tovább nehezíti, hogy egyazon tulajdonságra sok esetben a különböző szerzők eltérő néven hivatkoznak. Az alkalmazók számára az eligazodást megkönnyítendő, összefoglaltam,

hogyan feleltethetők meg egymásnak (illetve az általunk a 2.1. fejezetben definiált 
kritériumoknak) a különböző tanulmányok eltérő megközelítéseiben definiált tulajdonságok (3. melléklet).

Bár a kockázati tőke allokálására számtalan lehetséges módszer létezik, nincsen általánosan elfogadott legjobb megoldás. Ez részben annak köszönhető, hogy nincs olyan módszer, amely egyszerre teljesíteni tudná az összes, 2.1. fejezetben szereplő tulajdonságot. Csóka és Pintér (2016) bebizonyította, hogy koherens kockázatmérték alkalmazása esetén nincs olyan módszer, amely erősen monoton ${ }^{34}$, egyenlően kezelő és magbeli allokációt eredményez azaz e három, természetesen felmerülő követelmény közül legalább az egyikről le kell mondanunk. Ugyanezen tételből következik az is (ld. a 2. rész eredményeit), hogy nincs mindig értelmezett, ösztönző és magallokációt eredményező módszer. Tehát mindig a konkrét tőkeallokációs szituáció függvényében kell az alkalmazónak választania az egyes elvárt tulajdonságok, s így az allokációs módszerek között. Fontos mindemellett azt is látnunk, hogy a döntés meglehetősen komplex folyamat a gyakorlatban, hiszen számos, különböző motivációval rendelkező szereplő vehet részt benne - ha például üzletágakra szeretnénk allokálni a biztosító tőkéjét, akkor az egyes üzletágak vezetőinek, a kockázatkezelési vezetőnek és a cég menedzsmentjének más-más szempontokat kell szem elött tartania.

A módszerválasztás megkönnyítése érdekében az alábbiakban előbb csoportosítom az alkalmazható módszereket, majd néhány, a gyakorlatban fontos szempont alapján javaslok módszer(típus)t a különböző alkalmazásokhoz.

\footnotetext{
${ }^{34}$ Az egyes tulajdonságok magyarázata a 2.1. fejezetben található.
} 


\subsubsection{AZ ALKALMAZHATÓ MÓDSZEREK CSOPORTOSÍTÁSA}

\subsubsection{Arányos szétosztások}

Az ebbe a csoportba sorolható módszerek a teljes kockázatot $\left(\rho\left(X_{N}\right)\right)$ valamilyen arányszám segítségével osztják szét az alegységek között: $\varphi_{i}\left(X_{N}^{\rho}\right)=\alpha \rho\left(X_{i}\right)$, úgy, hogy $\sum_{i=1}^{N} \varphi_{i}\left(X_{N}^{\rho}\right)=\rho\left(X_{N}\right)$. E módszerek nagy előnye, hogy alkalmazásuk egyszerü, ugyanakkor matematikai tulajdonságaik kevésbé kedvezőek. Az arányos szétosztások között két módszert érdemes mindenképp említenünk. Az egyéni kockázattal arányos módszer (Hamlen et al., 1977) az egyes egységek által vállalt kockázat $\left(\rho\left(X_{i}\right)\right)$ arányában osztja szét a kockázatot, ami kézenfekvő megoldásnak tünhet, azonban nagy hibája, hogy nem veszi figyelembe a diverzifikációs hatást az egyes egységek között (vagyis, hogy az adott egység mennyivel járul hozzá a teljes biztosító kockázataihoz). Az arányos szétosztások közé sorolható még az ún. béta, vagy kovariancia módszer (ld. pl. Dhaene et al., 2012), amelynek számítása szintén viszonylag egyszerü, de már figyelembe veszi a diverzifikációs hatást is. Mindkét módszer tulajdonságainak részletes elemzése megtalálható a 2. részben.

\subsubsection{Kockázatnövekmény alapú szétosztások}

A kockázatnövekmény alapú módszerek - elnevezésüknek megfelelően - a kockázatot az egyes alegységek között az általuk okozott kockázatnövekményt figyelembe véve osztják szét. Két típust érdemes megkülönböztetni e módszereken belül is: az „utolsó belépő” típusú módszereket (Venter, 2009), melyek a teljes portfólión értelmezik a növekményt ( $\rho\left(X_{N}\right)$ $\left.\rho\left(X_{N \backslash\{i\}}\right)\right)$, illetve a Shapley-módszert, amely az adott egység átlagos határ-hozzájárulását veszi alapul.

Az „utolsó belépő” típusú módszerek a kockázatot tehát az adott egység által a teljes portfólión okozott kockázatnövekmény $\left(\rho\left(X_{N}\right)-\rho\left(X_{N \backslash\{i\}}\right)\right)$ alapján osztják szét. Ebbe a 
típusba sorolható a növekményi módszer (ld. 2.2.3. fejezet), a költségrés módszer (ld. 2.2.4. fejezet), illetve a Merton és Perold által javasolt módszer (Merton és Perold, 1993).

A fenti módszereknél szofisztikáltabb megoldást ad a játékelméletből jól ismert Shapleymódszer (Shapley, 1953), amely a kockázatot még mindig az adott egység által okozott kockázatnövekmény alapján osztja szét, de már nem csak a teljes biztosító adott egység nélküli portfóliójához $(N \backslash\{i\})$, hanem minden lehetséges $S \subseteq N \backslash\{i\}$ halmazhoz képest értékelve, s ezek átlagát véve. A Shapley-módszer nem véletlenül terjedt el: számos kedvező matematikai tulajdonsággal rendelkezik (ld. az analitikus vizsgálat eredményeit a 2.2.8. fejezetben).

\subsubsection{Marginális kockázati hozzájárulás alapú szétosztások}

A marginális kockázati hozzájárulás alapú szétosztások közé soroljuk az irodalomban sokat tárgyalt Euler-módszert (ld. pl. Tasche, 2008, illetve a 2.2.5. fejezetben), amely a kockázatmérték parciális deriválásával allokálja kockázatot, valamint az iránymenti deriválttal való szétosztást (ld. 2.2.5. fejezet). Az Euler-módszer, amennyiben definiált, optimális megoldás lehet az árazás során is; Tasche (2008) szerint továbbá teljesítményértékelés során is ideális választás, mivel összeegyeztethető a RORAC számítással ${ }^{35}$. Ebbe a csoportba sorolhatjuk még a szintén népszerủ Myers-Read módszert is (Myers és Read, 2001), amely a Merton-Perold módszerhez hasonlóan a biztosító tőkéjét a csődopció értékét alapul véve osztja szét üzletágakra, az Euler-módszer alkalmazásával. A Merton-Perold módszerrel szemben a Myers-Read allokáció a teljes tőkét felosztja az egyes alegységek között (azaz hatékony), és a kapott szétosztás egyértelmü.

\footnotetext{
${ }^{35}$ Formálisan egy módszer akkor RORAC-kompatibilis (Tasche, 2008), ha hatékony és léteznek olyan $\varepsilon_{i}>0$ számok, hogy $\operatorname{RORAC}\left(X_{i} \mid X\right)>\operatorname{RORAC}(X) \Rightarrow \operatorname{RORAC}\left(X+h X_{i}\right)>\operatorname{RORAC}(X)$ minden $0<h<\varepsilon_{i}$-re, ahol RORAC $\left(X_{i} \mid X\right)$ és $R O R A C(X)$ a 3.1.1. fejezetben definiált kifejezések.
} 


\subsubsection{MóDSZERVÁLASZTÁS AZ ALKALMAZÁS FÜGGVÉNYÉBEN}

Mint említettem, a tőkeallokációs módszerek között nincsen általánosan alkalmazható legjobb megoldás, a módszer választását mindig az felhasználás céljához szükséges igazítani. Az alkalmazott módszer kiválasztásához Albrecht (2006) a 2.1. fejezetben definiált egzakt követelményekkel szemben (a teljes allokációt ő is alapfeltételnek tekinti) a gyakorlati alkalmazás szempontjából releváns szempontokat fogalmaz meg. Eszerint fontos, hogy az allokáció a teljes vállalati szinten alkalmazott gazdasági kockázatméréssel konzisztens módon történjen; hogy milyen tulajdonságokkal rendelkező kockázatmértéket használ a vállalat; hogy az egyes szegmensek veszteségei közötti függőségek hogyan kerülnek figyelembe vételre; a gyakorlatban hogyan implementálható az adott módszer; illetve, hogy a választott allokációs módszer az alkalmazási célnak megfelelő tulajdonságokkal rendelkezzen. Ruhm és Wolf (2015) szintén fontos szempontként veti fel, hogy az alkalmazott allokációs módszer legyen elfogadható a szervezet minden szereplöje számára, időben stabil legyen és ne allokáljon egy alegységre sem negatív tőkét.

Az alábbiakban a gyakorlati alkalmazásra koncentrálva a matematikai tulajdonságok közül a diverzifikáció követelményére fókuszálok, amely azt az elvárást fejezi ki, hogy az egyes egységekre allokált tőke ne haladja meg az adott egység önálló kockázatát. Bár az „önálló kockázat” egy-egy üzletág, vagy termékportfólió vonatkozásában nem feltétlenül releváns viszonyítási alap, hiszen az egyes üzletágak jellemzően nem tudnának önálló egységként müködni, a követelmény mégis fontos kritériuma a módszer ,igazságos” voltának, s ezáltal nagyban segíti a módszer elfogadtatását az érintett döntéshozókkal. Emellett fontos szempont az allokációs mechanizmus átláthatósága, viszonylagos egyszerüsége is. A gyakorlati alkalmazás során a fenti szempontok elsődleges szerepét támasztotta alá Homburg és Scherpereel (2008) valós szereplők segítségével végzett kísérlete. A szerzők 
azt találták, hogy valós gazdasági szereplők korlátozott racionalitása miatt az elosztás „észlelt” igazságosságát jobban befolyásolja az allokációs mechanizmus átláthatósága, egyszerüsége, illetve az individuális racionalitásnak követelményének való megfelelés, mint az irodalomban legtöbbször megjelenő magallokáció feltételének kielégítése. Szintén nagyon fontos szempont a gyakorlatban a módszer hatékonysága, vagyis azt, hogy a módszer a teljes kockázatot ossza szét az egyes üzletágak között, így Kalkbrenerrel (2005), Albrechttel (2006) és számos további szerzővel összhangban, a táblázatban csak ennek a kritériumnak megfelelő módszereket szerepeltetek - így azt nem is tüntetem fel külön az egyes módszerek előnyei között.

Rátérve a különböző alkalmazásokra, stratégiai döntések (tervezett felvásárlások, összeolvadások, új üzletág indításának értékelése, vagy létező üzletág megszüntetéséről való döntés) támogatására a kockázatnövekmény alapú módszerek, ezek közül is az utolsó belépő típusúak alkalmasak leginkább, hiszen ilyen esetekben valóban fixnek feltételezhetjük a teljes portfóliót, s a szóban forgó üzletág ehhez való viszonya alapján döntünk. Így érvel Merton és Perold $(1993, p 29)$ is, akik szerint, ,a marginális döntések ${ }^{36}$ során a tőke marginális költségét figyelembe venni”, illetve Buch et al. (2011), akik szerint a módszerválasztást az alegységek összetételéhez, jellegéhez is kell igazítani: kisszámú, heterogén alegység esetén (ilyenek az üzletágak megszüntetéséről, új üzletágak indításáról való döntések, és az üzletágak teljesítményének értékelése) inkább valamely kockázatnövekmény alapú allokációs módszer a megfelelő. Teljesítményértékelés során szintén optimális megoldás lehet a Shapley-módszer használata, amelynek számítása ugyan bonyolultabb, de az eredménye stabilabb, és talán igazságosabbnak is tekinthető, mint az utolsó belépő típusú módszereké.

\footnotetext{
${ }^{36}$ Értelmezésükben ez az adott üzletágból történő kilépésre, vagy új üzletág indítására vonatkozik.
} 
Termékárazás során, amikor az alegységek többé-kevésbé homogének, és a portfóliójukban nagyszámú szerződés szerepel, a differencia alapú módszerek megfelelőbbek. Emiatt, bár Tasche (2008) szerint az Euler-módszer ideális teljesítményértékelés során is, én inkább az árazásban való alkalmazását javaslom. Hasonló következtetésre jut Myers és Read (2001) is, akik megmutatják, hogy az általuk ajánlott allokációs módszer megfelelő az árazásban való használathoz, mivel az egyes üzletágakra allokált tőke nem reagál érzékenyen új üzletágak hozzáadására - ugyanezen okból viszont új üzletágakkal, üzletágak megszüntetésével kapcsolatos döntések során kevésbé alkalmas.

Amennyiben a tőkeallokáció célja kizárólag külső (szabályozói, vagy akár anyavállalati) elvárásnak való megfelelés, akkor indokolt lehet a legegyszerübben alkalmazható arányos módszerek alkalmazása is (a kettő közül az egyéni kockázattal arányos módszer implementálható a legkönnyebben).

Az alábbi összefoglaló táblázatban áttekintem, hogy az egyes alkalmazásokhoz mely módszerek illeszkednek leginkább. Az egyes módszereknél (módszertípusoknál) feltüntetem a gyakorlati alkalmazás során leginkább releváns előnyöket és hátrányokat. A megfelelő módszer kiválasztásához további segítségként szolgálhat a korábbi, analitikus vizsgálat eredményeit összegző 19. táblázat is. 


\begin{tabular}{|c|c|c|c|c|}
\hline $\begin{array}{l}\text { Az allokáció } \\
\text { célja }\end{array}$ & $\begin{array}{l}\text { Javasolt } \\
\text { módszer típus }\end{array}$ & $\begin{array}{l}\text { Javasolt } \\
\text { módszer }\end{array}$ & Előnyök & Hátrányok \\
\hline $\begin{array}{l}\text { Teljesítmény- } \\
\text { értékelés }\end{array}$ & $\begin{array}{l}\text { Kockázat- } \\
\text { növekmény } \\
\text { alapú }\end{array}$ & $\begin{array}{l}\text { Shapley- } \\
\text { módszer }\end{array}$ & $\begin{array}{ll}\text { - } & \text { Div }^{37} \\
\text { - } & \text { Világos } \\
\text { interpretáció } \\
\text { - Kedvező egyéb } \\
\text { matematikai } \\
\text { tulajdonságok } \\
\end{array}$ & $\begin{array}{l}\text { - Számítása } \\
\text { viszonylag } \\
\text { bonyolult }\end{array}$ \\
\hline \multirow[t]{2}{*}{$\begin{array}{l}\text { Teljesítmény- } \\
\text { értékelés \& } \\
\text { Stratégiai } \\
\text { döntések }\end{array}$} & \multirow[t]{2}{*}{$\begin{array}{l}\text { Kockázat- } \\
\text { növekmény } \\
\text { alapú (utolsó } \\
\text { belépö) }\end{array}$} & $\begin{array}{l}\text { Növekményi } \\
\text { módszer }\end{array}$ & $\begin{array}{l}\text { - Alkalmazása } \\
\text { egyszerü } \\
\text { - Világos } \\
\text { interpretáció }\end{array}$ & $\begin{array}{ll}\text { - } & \text { Nem Div } \\
\text { - A növekmény lehet } \\
\text { negatív, ami } \\
\text { intuíció-ellenes } \\
\text { szétosztást } \\
\text { eredményez } \\
\end{array}$ \\
\hline & & Költségrés & $\begin{array}{l}\text { - Div } \\
\text { - Világos } \\
\text { interpretáció }\end{array}$ & $\begin{array}{l}\text { - Számítása } \\
\text { viszonylag } \\
\text { bonyolult }\end{array}$ \\
\hline Árazás & $\begin{array}{l}\text { Marginális } \\
\text { kockázati } \\
\text { hozzájárulás }\end{array}$ & $\begin{array}{l}\text { Euler-módszer } \\
\text { / Myers-Read } \\
\text { módszer }\end{array}$ & $\begin{array}{l}\text { - A gyakorlatban Div } \\
\text { - Számítása egyszerü } \\
\text { az RMK } \\
\text { algoritmus } \\
\text { segítségével } \\
\end{array}$ & $\begin{array}{l}\text { - } \text { Bizonyos } \\
\text { körülmények között } \\
\text { instabil eredmény }\end{array}$ \\
\hline $\begin{array}{l}\text { Külső elvárás } \\
\text { esetén }\end{array}$ & Arányos & $\begin{array}{l}\text { Egyéni } \\
\text { kockázattal } \\
\text { arányos / Béta } \\
\text { módszer }\end{array}$ & $\begin{array}{l}\text { - Egyszerü } \\
\text { alkalmazás } \\
\text { - Világos } \\
\text { interpretáció }\end{array}$ & $\begin{array}{ll}\text { - } & \text { Nem Div } \\
\text { - } & \text { Legkevésbé } \\
\text { kedvezö } \\
\text { matematikai } \\
\text { tulajdonságok }\end{array}$ \\
\hline
\end{tabular}

\footnotetext{
${ }^{37}$ Diverzifikáló, azaz individuálisan racionális és hatékony.

${ }^{38}$ RMK: Ruhm-Mango Kreps algoritmus, ld. pl. Ruhm és Mango (2003)

${ }^{39}$ A módszer lényege, hogy az egyes portfóliókra allokált kockázat az alapján határozódik meg, hogy milyen a realizációjuk a teljes portfólió kockázatát meghatározó világállapotokban. (Pl.: maximális veszteség alkalmazás esetén mennyi az egyes alegységek vesztesége, amikor a teljes portfólió vesztesége maximális.) Amennyiben kevés adatpontot használunk a nagykoalíció kockázatának meghatározása során, akkor az eredmény esetlegessé válhat.
} 


\subsection{KöVETKEZTETÉSEK}

Bár a tőkeallokáció szakirodalma igen gazdag, s számos különböző lehetséges módszert alkottak a terület szakértői, a témában született tanulmányok túlnyomó többségében a szerzők kívánatos, vagy kívánatosnak vélt matematikai tulajdonságokból származtatják módszereiket, nem pedig a biztosítók tőkeallokációs gyakorlata során felmerült igények alapján. A disszertáció jelen részének célja az elmélet és gyakorlat közti távolság áthidalása, egyfajta útmutatót szolgáltatva a különféle módszerek közötti választáshoz, a kiválasztott módszer implementálásához, de talán már magának a tőkeallokációs problémának a megfogalmazásához is.

A tőkeallokáció első lépése annak meghatározása, hogy milyen típusú tőkét allokálunk. Fontos megkülönböztetni a szabályozó tőkekövetelményt, a gazdasági tőkeszükségletet, valamint a rendelkezésre álló tőkét. Megállapítottuk, hogy allokálni mindig gazdasági tőkeszükségletet érdemes, hiszen ez tükrözi valójában a vállalat kockázati profilját.

Mivel a tőkeallokációs problémára nem létezik univerzális, minden helyzetben alkalmazható legjobb megoldás, a módszerválasztás során mindig a felhasználás céljához szükséges igazodni. Azonosítottam a biztosítóknál a tőkeallokáció három fő alkalmazási területét, és javaslatot tettem arra vonatkozóan, hogy az egyes esetekben mely típusú módszereket érdemes alkalmazni, s ezek milyen előnyökkel és hátrányokkal rendelkeznek (23. táblázat). Mind a teljesítményértékelés során történő alkalmazásra, mind pedig stratégiai döntések támogatására leginkább a kockázatnövekmény alapú módszerek megfelelőek, melyek az egyes alegységek között az általuk okozott kockázatnövekményt figyelembe véve osztják szét a teljes kockázatot. Stratégiai döntések során a legalkalmasabbak az „utolsó belépő” típusú módszerek (amelyek azt vizsgálják, hogyan változik a teljes portfólió kockázata az adott egység hozzáadásával/elvételével), míg teljesítményértékelés során stabilabb és 
kedvező tulajdonságokkal bíró allokációt eredményez a játékelméletből jól ismert Shapleymódszer. A harmadik fontos alkalmazási terület az árazás, bár itt a szakértők között vita zajlik a tekintetben, hogy szükséges-e allokációs módszerek használata. Amennyiben a tőkeallokáció segítségével történik az árazás, akkor e célból a legmegfelelőbbek a marginális kockázati hozzájárulás alapú módszerek: az Euler-módszer, és ennek speciális alkalmazása, a Myers-Read módszer. Külső elvárásnak való megfelelés céljából, amikor a biztosító ténylegesen nem használja fel az allokáció eredményét, a legcélszerübb az egyszerủ arányos szétosztások alkalmazása.

Az adott szituációban leginkább megfelelő módszer választásához további segítségként összefoglaló táblázatban jelenítettem meg, hogy a különböző szerzők milyen különböző neveken hivatkoznak a módszerek lehetséges matematikai tulajdonságaira (3. melléklet). 


\section{RÉSZ: ESETTANULMÁNY - TELJESÍTMÉNYÉRTÉKELÉS AZ ABC}

\section{BiZTosíTó ZRT.-NÉL}

A tőkeallokációs probléma kézzelfoghatóbbá tételének érdekében a dolgozat jelen, utolsó részében a korábban tárgyaltakat egy gyakorlati példa segítségével is illusztrálom. A tőkeallokációt egy fiktív biztosítótársaság, az ABC Zrt. példáján mutatom be a következő esettanulmányban. Az $\mathrm{ABC}$ Zrt.-nek három üzletága van: a gépjármü biztosítás, lakásbiztosítás, és szakmai felelősségbiztosítás, illetve saját befektetési részleggel is rendelkezik, melynek egyetlen feladata a biztosító által beszedett díjak befektetése.

Az ABC Zrt. minden évben egységes módszertan szerint értékeli az üzletágai teljesítményét. Mivel a befektetési divízió - hasonlóan a másik három üzletághoz - is önálló profit centerként müködik, így annak teljesítményét is külön egységként értékeli a biztosító. A teljesítményértékelés eredménye egyrészt a javadalmazás során kerül felhasználásra (meghatározza az egyes üzletágakban dolgozók között szétosztható prémium „,pool”-ok nagyságát), másrészt fontos inputként szolgál az üzleti stratégia alakítása során is.

A biztosító üzletágainak teljesítményét a RORAC mutató segítségével értékeli, azaz az egyes üzletágak által elért jövedelmet a vállalt kockázathoz, pontosabban a lekötött tőkéhez viszonyítva értékeli, melyet a biztosító a gazdasági tőkéjének üzletágakra történő allokálásával mér.

Egyszerüsített modellel dolgozom, üzletáganként mindössze a kárigényeket, a müködési költséget, valamint a befektetési részleg esetében az elért hozamot modellezem. Egy adott időperiódust, és zárt állományokat vizsgálok (azaz a szerződések száma fix, a vizsgált időszakban nem köttetnek újabb szerződések, illetve nem is szünnek meg). A vizsgálat során feltételezem, hogy a biztosító a teljes kárigényt megtéríti még az adott időperiódusban, így 
tartalékolással sem foglalkozom. Szintén nem képezik a vizsgálat tárgyát adózási kérdések sem.

\subsection{A MODELL FELÉPÍTÉSE}

\subsubsection{GÉPJÁRMŰ FELELŐSSÉGBIZTOSÍTÁS}

Modellemben a gépjármü felelősségbiztosítás állománya $N_{G F}=1000$ szerződésböl áll. Feltesszük, hogy egy szerződésre legfeljebb egy kárigény kerül benyújtásra. Az egyedi kárigények eloszlása exponenciális $\lambda=0,05$ paraméterrel, azaz az egyedi károk várható értéke és szórása az alábbiak szerint alakul:

$$
\begin{aligned}
& E\left(X_{G F}\right)=\frac{1}{\lambda}=\frac{1}{0,05}=20, \\
& D\left(X_{G F}\right)=\frac{1}{\lambda}=\frac{1}{0,05}=20,
\end{aligned}
$$

vagyis egy kár várható értéke és szórása is 20 pénzegység (a továbbiakban PE).

A szerződések nagy számára való tekintettel, a centrális határeloszlás tétele alapján a teljes állomány kárigényét normális eloszlással közelítem, melynek várható értéke és szórása az alábbiak szerint alakul:

$$
\begin{gathered}
E\left(S_{G F}\right)=N * E\left(X_{G F}\right)=1000 * 20=20000, \\
D\left(S_{G F}\right)=\left(N * D^{2}\left(X_{G F}\right)\right)^{0,5}=(1000 * 400)^{0,5} \approx 632,46 .
\end{gathered}
$$

Az állomány kárigénye mellett a modellben véletlen változónak tekintem még a müködési költség alakulását is, amely tartalmazza a kifizetésekhez, illetve a szerzéshez kapcsolódó költségeket is. Az egyszerüség kedvéért a müködési költségről szintén tegyük fel, hogy normális eloszlású, a gépjármü felelösségbiztosítás üzletág esetében $E\left(O P_{G F}\right)=1000$ 
várható értékekkel és $D\left(O P_{G F}\right)=100$ szórással, amely várható értékben 5\%-os költséghányadot jelent a díjbevételhez viszonyítva.

A beszedett díjat $\left(F_{G F}\right)$ fixnek tekintem. A biztosító úgy árazza termékeit, hogy egy szerződés díja 75\%-os valószínüséggel fedezze a kockázati költséget, továbbá ehhez adódik hozzá az egy szerződésre eső várható müködési költség, vagyis:

$$
\begin{aligned}
& F_{G F}=\frac{\Phi^{-1}(0,75) * D\left(S_{G F}\right)+E\left(S_{G F}\right)}{1000}+\frac{E\left(O P_{G F}\right)}{1000} \approx \frac{0,67 * 632,46+20000}{1000}+\frac{1000}{1000} \\
& \approx 21,43 .
\end{aligned}
$$

A fenti paramétereknek megfelelően minden üzletág esetében 10000 futtatást végeztem, hogy szimuláljam az üzletág által elért müködési eredményt. Az eredmények összevethetőségének érdekében ezeket a fejezet végén, egy közös ábrán (5. ábra) jelenítettem meg.

\subsubsection{LAKÁSBIZTOSÍTÁS}

A gépjármü felelősségbiztosítással teljesen analóg módon modelleztem a lakásbiztosítás üzletágat, egyedül az alkalmazott paraméterek különböztek. Az állomány ezúttal $N_{L}=800$ szerződést tartalmaz. Az egyedi károk exponenciális eloszlásának paramétere $\lambda_{L}=0,1$, vagyis az egyedi káresemények várható értéke és szórása:

$$
E\left(X_{L}\right)=D\left(X_{L}\right)=\frac{1}{\lambda}=\frac{1}{0,1}=10
$$

A teljes állomány kárigényét ismét normális eloszlással közelítem, a következő paraméterekkel:

$$
\begin{gathered}
E\left(S_{L}\right)=N * E\left(X_{L}\right)=800 * 10=8000, \\
D\left(S_{L}\right)=\left(N * D^{2}\left(X_{L}\right)\right)^{0,5}=(800 * 100)^{0,5} \approx 283,84 .
\end{gathered}
$$


A továbbra is normális eloszlásúnak tekintett müködési költség várható értéke $E\left(O P_{L}\right)=$ 500 , szórása pedig $D\left(O P_{L}\right)=50$, azaz a költséghányad a lakásbiztosítás esetében $6 \%$.

A díjakat ismét úgy határozza meg a biztosító, hogy a kockázati költséget 75\%-os biztonsággal fedezze, valamint fedezze a működési költség várható értékét:

$$
F_{L}=\frac{\Phi^{-1}(0,75) * D\left(S_{L}\right)+E\left(S_{L}\right)}{800}+\frac{E\left(O P_{L}\right)}{800} \approx \frac{0,67 * 283,84+8000}{800}+\frac{500}{800} \approx 10,86
$$

\subsubsection{SZAKMAI FELELÖSSÉGBIZTOSÍTÁS}

Az ABC Zrt. harmadik vizsgált üzletága szakmai felelősségbiztosítást értékesít egészségügyi és szociális dolgozók számára. Az üzletág szerződésállománya kicsi $\left(N_{S z F}=\right.$ 100). Ennek következtében az állomány normális eloszlásának feltételezése helyett külön modelleztem az egyedi kárnagyságot, illetve külön az állományban bekövetkező károk számát, s így kaptam a teljes állomány kárnagyságát.

Az egyedi kárnagyságra lognormális eloszlást feltételeztem, $m=2,5$, illetve $s=1,5$ paraméterek mellett, így az egyedi káresemények várható értéke és szórása:

$$
\begin{gathered}
E\left(X_{S Z F}\right)=e^{m+\frac{1}{2} s^{2}} \approx 37,52, \\
D\left(X_{S Z F}\right)=e^{m+\frac{1}{2} s^{2}} * e^{s^{2}-1}=130,97 .
\end{gathered}
$$

Látható, hogy jelen esetben a gépjármü felelősségbiztosításnál, illetve a lakásbiztosításnál alkalmazott egyedi káreloszláshoz képest nagyobb szórású eloszlással dolgoztam, mivel a szakmai felelősségbiztosítás jellegéből adódóan az egyedi károk nagysága jóval nagyobb mértékben szóródik, mint a másik két üzletág esetében.

A kárgyakoriság modellezésére az irodalomban jellemzően negatív binomiális, binomiális vagy Poisson eloszlást alkalmaznak, én a modellemben binomiális eloszlást választottam, 
$n=100$, és $p=0,1$ paraméter mellett, azaz a 100 szerződésből álló állományban egy év alatt 10 káresemény bekövetkezésére számítunk.

A jelen esetben is normális eloszlásúnak tekintett müködési költség várható értéke $E\left(O P_{S z F}\right)=200$, szórása pedig ismét $D\left(O P_{S z F}\right)=50$.

A díjakat a szakmai felelősségbiztosítás esetében is az elözőekkel analóg módon határozza meg a biztosító, azonban az állomány kockázatosabb jellegéből adódóan a kockázati költségek 95\%-os valószínűséggel való megtérülésével számol. A díjat a fenti paraméterek mellett (50 000 elemszámú) szimuláció segítségével határoztam meg:

$$
F_{S Z F}=11,52
$$

\subsubsection{BEFEKTETÉSEK}

$\mathrm{Az} \mathrm{ABC}$ biztosítónak a három üzletága mellett befektetési részlege is van. Ennek feladata, hogy a biztosító által beszedett díjak egy részét (melyet az adott időszakban várhatóan nem használnak fel kárkifizetésre vagy egyéb költségekre) befektesse. Az ABC Zrt. a vizsgált periódusban a beszedett díjak 50\%-át fekteti be - ez egy tetszőlegesen választott érték, a tartalékolás kérdésével itt nem foglalkozom, csak a tőkeallokáció bemutatására koncentrálok. A müködési költségeket itt is normális eloszlásúnak tekintettem. A müködési költség a befektetési részleg esetében a legkevésbé volatilis, várható értéke $E\left(O P_{B}\right)=200$, szórása pedig $D\left(O P_{B}\right)=30$.

A befektetési részleg által elért hozamot a pénzügyi adatok esetében gyakran alkalmazott, vastagszélü Student-t eloszlással modelleztem (Cont, 2001; Mandelbrot, 1963), 5 szabadságfokkal. 


\section{Az egyes üzletágak múködési eredménye}

A fentiekben bemutatott paraméterek segítségével előállítható az egyes üzletágak (szimulált) müködési eredménye - tekintsük ezt az éves eredménynek. A modellt 10 000-szer lefuttattam, azaz 10000 évnyi adatot szimuláltam, ebböl pedig nagy pontossággal ki tudtam számítani az ABC biztosító tőkekövetelményét, valamint az egyes üzletágakra allokált tőkét is.

Az egyes üzletágak által elért eredmény eloszlását a lenti 5. ábra mutatja. Az eloszlásokon jól látszanak a feltételezett mögöttes eloszlások közötti különbségek: az első két üzletág eredménye a normális eloszlás haranggörbéje szerint alakul, a szakmai felelösségbiztosításé jellegzetesen balra ferde, míg a befektetéseké szimmetrikus, de a normális eloszlásnál vastagabb szélekkel rendelkezik. Az egyes üzletágak által elért eredményt függetlennek tekintjük, ami a károk esetében reális feltételezés az egyes üzletágak által értékesített termékek különböző jellegéböl adódóan. (A müködési költségeknél már kevésbé, ugyanakkor csak feleslegesen bonyolítanánk a modellt a korreláció figyelembevételével.)

5. ábra: Az ABC Zrt. egyes üzletágai által elért müködési eredmény

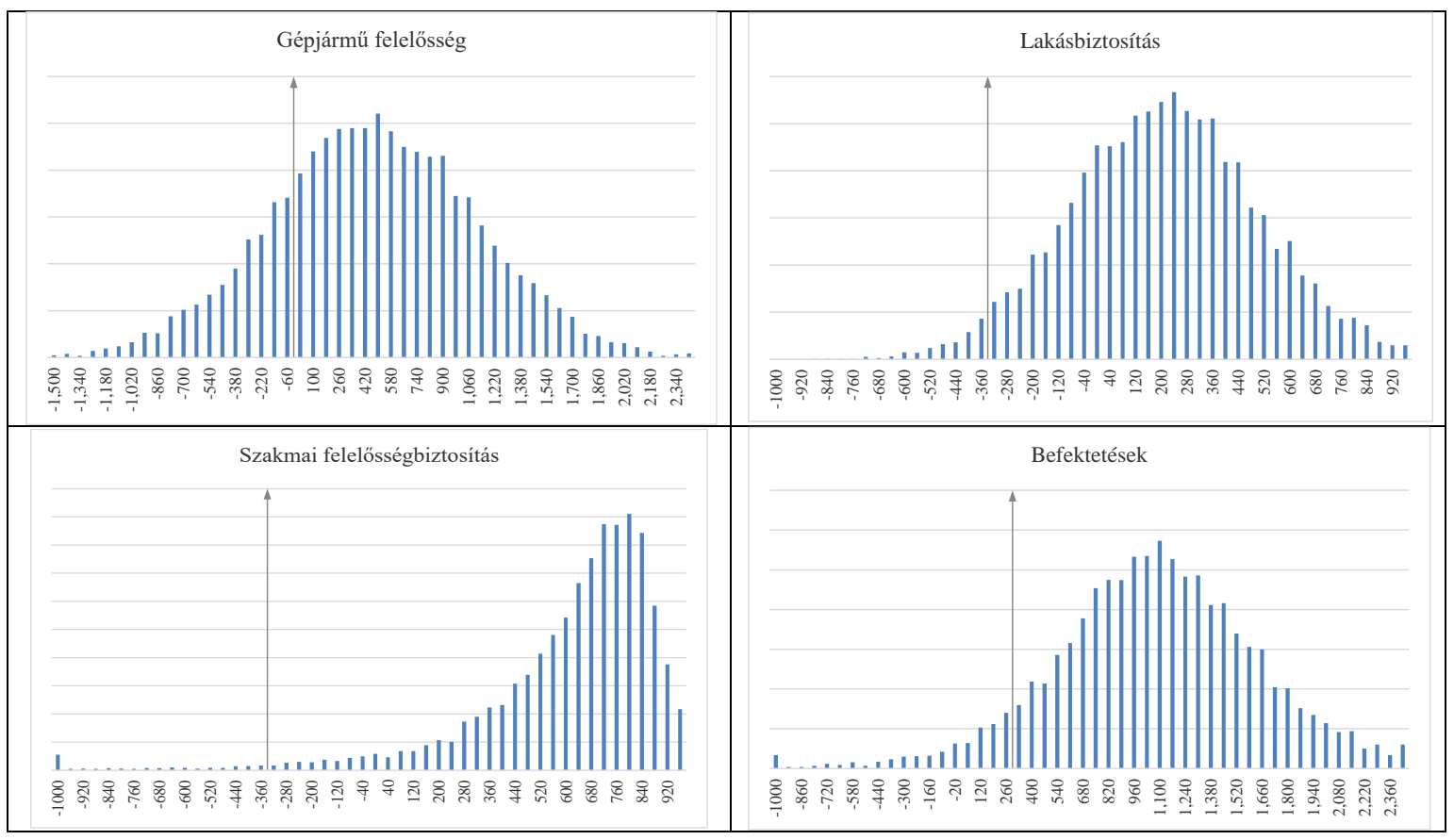




\subsection{KOCKÁZAT- ÉS TŐKEKÖVETELMÉNY SZÁMÍTÁS}

Az ABC Zrt. a teljesítményértékelés során a saját belső módszertana szerint számított gazdasági tőkéjét használja a kockázattal korrigált hozam (RORAC) számításakor. A társaság, összhangban a kockázati stratégiájában meghatározott prudens kockázatértékelési alapelvekkel, belső gazdasági tőkéjét 99\%-os szignifikancia szint melletti Expected Shortfall-lal számszerüsíti, amely a modellben a Szolvencia II szabályozás által elvárt 99,5\%-os VaR-nál konzervatívabb kockázatértékelést eredményez. A tőkekövetelmény kiszámításához első lépésként összesítettem az egyes üzletágak eredményét, hogy megkapjam a teljes vállalat éves eredményét. Az ABC Zrt. eredményének eloszlását, illetve a 10 000-es elemszámú szimuláció segítségével számított 99,5\%-os VaR-t, illetve a 99\%-os Expected Shortfall-t az alábbi ábra mutatja.

6. ábra: Az ABC Zrt. éves nettó eredményének eloszlása és kockázata

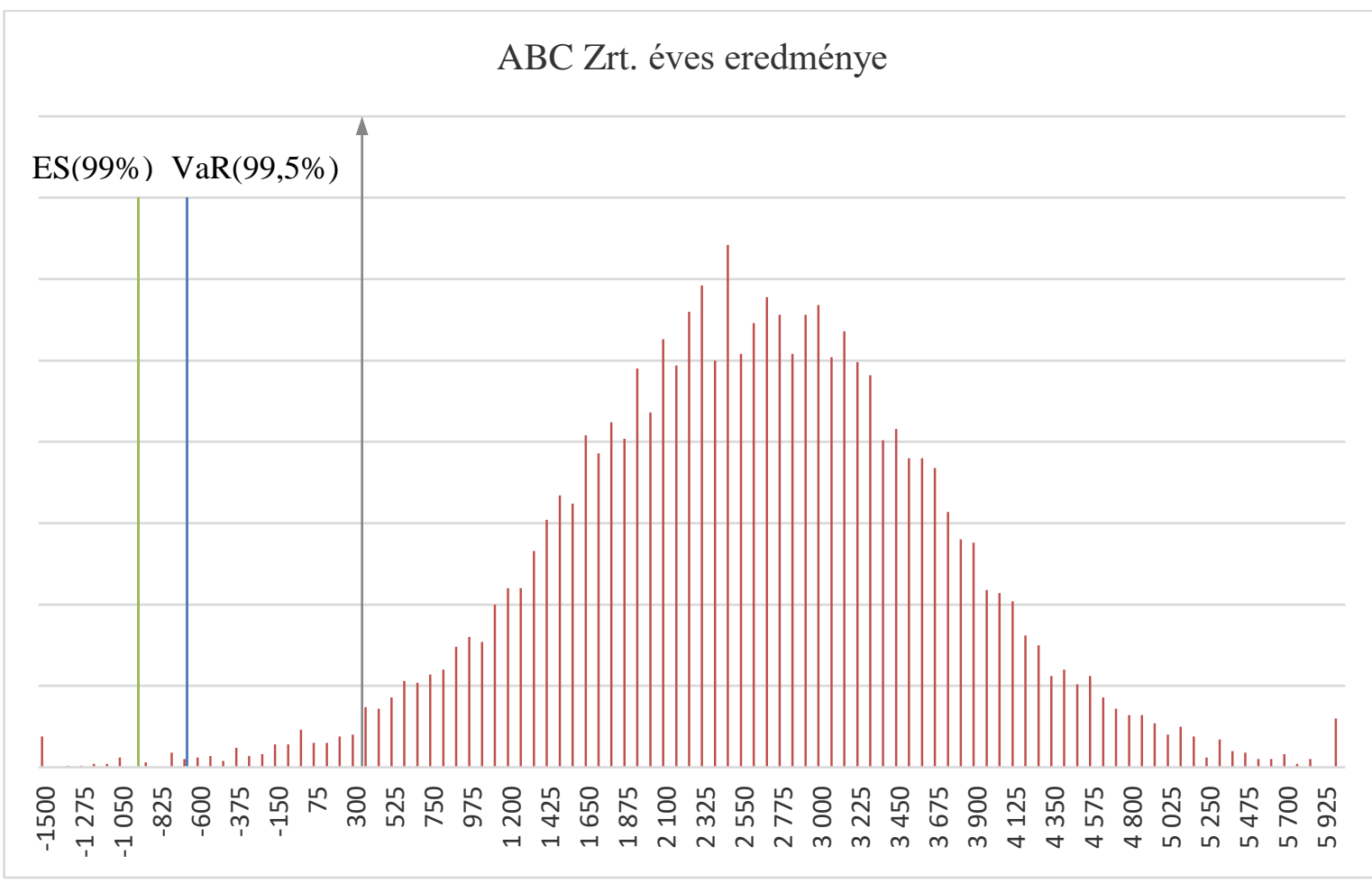


A 99,5\%-os VaR a modell szerint 646 PE, a 99\%-os Expected Shortfall 1012 PE-nek adódott.

\subsubsection{TŐKEALLOKÁCIÓ ÉS TELJESÍTMÉNYÉRTÉKELÉS}

Az ABC Zrt. a 3.1.1. fejezetben definiált RORAC koncepció szerint értékeli üzletágainak teljesítményét. Egy adott üzletág RORAC-ja tehát (figyelembe véve, hogy jelen esetben ex post teljesítményt értékelünk):

$$
\operatorname{RORAC}\left(X_{i} \mid X\right)=\frac{X_{i}}{\varphi_{i}\left(X_{N}^{\rho}\right)}
$$

ahol $X_{i}$ az adott üzletág által elért nettó eredmény, $\varphi_{i}\left(X_{N}^{\rho}\right)$ pedig az $i$ üzletágra allokált tőkét jelöli.

\subsubsection{NETTÓ EREDMÉNYEK}

A nettó eredmény értékeléséhez a 3.3. fejezetben már említett korrekciót végzi el a biztosító a befektetési divízió esetében: a részleg eredményének a kockázatmentes befektetéshez képest elért többlethozamot tekinti (azaz a kockázatmentesen elérhető hozammal csökkenti a ténylegesen elért eredményt), a többi üzletág eredményéhez pedig hozzáadja ezt a kockázatmentesen elérhető hozamot (értelemszerüen a befektetésre átadott díjállomány arányában). Így ahhoz az alternatív szcenárióhoz képest értékeljük az eredményt, mintha a befektetési részleg nem létezne, $\mathrm{s}$ egyszerüen kockázatmentes befektetésbe (pl. állampapírba) fektetné azt a biztosító. Esetünkben az ABC Zrt. egyes üzletágainak nettó eredményei, a befektetésekkel kapcsolatos korrekció, illetve a korrigált nettó eredmény az alábbiak szerint alakultak: 


\begin{tabular}{|c|c|c|c|c|}
\hline & Gépjármü fel. & Lakás & Szakmai fel. & Befektetés \\
\hline Nettó eredmény & 315 & 218 & 300 & 825 \\
\hline Korrekció & 171 & 70 & 9 & -250 \\
\hline Korr. eredmény & 486 & 288 & 309 & 575 \\
\hline
\end{tabular}

\subsubsection{TöKEALLOKÁCIÓ}

Nézzük meg első lépésben kicsit közelebbről az ABC Zrt. gazdasági tőkekövetelményét! Számítsuk ki külön-külön minden üzletágra a 99\%-os Expected Shortfall-t, és vessük össze ezek összegét a kapott tőkekövetelménnyel!

25. táblázat: Az egyes üzletágak és a teljes ABC Zrt. kockázata (99\% Expected Shortfall)

\begin{tabular}{|c|c|c|c|c|}
\hline Gépjármú fel. & Lakásbiztosítás & Szakmai fel. & Befektetés & ABC Zrt. \\
\hline 1290 & 585 & 1456 & 1384 & 1012 \\
\hline
\end{tabular}

Láthatjuk, hogy igen jelentős megtakarítás keletkezik a diverzifikáció eredményeképp, hiszen ha összeadnánk az egyes üzletágak önálló kockázatát, ezek összege 4715 PE lenne, ezzel szemben az ABC Zrt. tőkekövetelménye mindössze 1012 PE. A diverzifikációs megtakarítást az 2.2. fejezetben bemutatott módszerek segítségével tudunk szétosztani az egyes üzletágak között. Az ABC Zrt. esetében négy módszer szerint is elvégeztem a tőkekövetelmény allokációját. A 3.4.1. fejezetben felsorolt mindhárom kategóriából választottam módszert: az egyéni kockázattal arányos módszert az arányos szétosztások közül; a Shapley, valamint a növekményi módszert a kockázatnövekmény alapú elosztások közül; a marginális kockázat alapú hozzájárulások közül pedig a leggyakrabban alkalmazott 
parciális deriváltként értelmezett marginális kockázati hozzájárulást, más néven az Euler módszert.

26. táblázat: A gazdasági tőke allokációja 4 különbözö módszer segitségével

\begin{tabular}{|c|c|c|c|c|}
\hline & Gépjármú fel. & Lakásbizt. & Szakmai fel. & Befektetés \\
\hline Egyéni kock. arányos & 277 & 126 & 313 & 297 \\
\hline Shapley & 334 & 88 & 372 & 217 \\
\hline Növekményi & 149 & 100 & 229 & 534 \\
\hline Euler & 231 & -15 & 397 & 400 \\
\hline
\end{tabular}

Látható, hogy az egyes módszerek jelentősen eltérő értékeket eredményeznek, még a sorrend sem egyezik. Ez ismét arra hívja fel a figyelmet, hogy a tőkeallokációs módszerek nem rutinszerüen alkalmazható eljárások, és rendkívül fontos körültekintően eljárni az adott szituációban megfelelő módszer kiválasztásakor.

Az ABC Zrt. a teljesítményértékelés során történő alkalmazáshoz a Shapley-módszert választja a tőke allokációjára. Az egyéni kockázattal arányos módszer a korábban említetteknek megfelelően általában nem javasolt módszer, hiszen nem veszi figyelembe a diverzifikációs hatást az egyes üzletágak között. Az Euler módszert azért zárta ki a biztosító, mert egyrészt a kockázatnövekmény alapú módszerek jobban illeszkednek a teljesítményértékelés során való alkalmazáshoz, másrészt pedig, mint látható, a lakásbiztosítási üzletágra az Euler módszer negatív tőkét allokál, melynek értelmezése problémás. A Shapley- és a növekményi módszer közül az ABC Zrt. végül - részben a módszer kedvező tulajdonságai (ld. az 2.2.6. fejezetben) miatt, részben pedig azért, mert stabilabb eredményt ad, mint akár az Euler, akár a növekményi módszer - a Shapleymódszer alkalmazása mellett dönt. A szimulációk során azt tapasztaltuk ugyanis, hogy ha a 
növekményi módszer alapját képező kockázatnövekmények összege (amely a számítás során a nevezőben szerepel) viszonylag kicsi, akkor meglehetősen extrém értékeket is eredményezhet a módszer, a Shapley módszer eredménye jóval kisebb ingadozást mutatott.

\subsubsection{TELJESÍTMÉNYÉRTÉKELÉS}

Végül tehát a biztosító egyes üzletágainak RORAC mutatója a korrigált nettó eredményt, valamint a Shapley-módszer eredményezte tőkeallokációt alapul véve a következő szerint alakult.

27. táblázat: A RORAC mutató alakulása üzletáganként

\begin{tabular}{|c|c|c|c|c|}
\hline & Gépjármú fel. & Lakásbizt. & Szakmai fel. & Befektetés \\
\hline Korr. eredmény & 529 & 305 & 312 & 512 \\
\hline Allokált kockázat & 334 & 88 & 372 & 217 \\
\hline RORAC & $158 \%$ & $345 \%$ & $84 \%$ & $236 \%$ \\
\hline
\end{tabular}

A kockázattal korrigált jövedelmezöség alapján tehát a lakásbiztosítás üzletág teljesít a legjobban, a leggyengébb teljesítményt pedig a szakmai felelösségbiztosítás üzletág produkálja. Az ABC Zrt. az elve kis szerződésállományra való tekintettel végül egyéb üzleti okok miatt, de a fenti elemzés által is megerősítve a szakmai felelősségbiztosítás üzletág leépítése mellett dönt a középtávú stratégiájának kialakítása során. 


\section{ÖSSZEGZÉS}

Nem megkérdőjelezve az alapkutatás jelentőségét, személy szerint hozzám jóval közelebb áll az alkalmazott kutatás, melynek haszna kézzelfoghatóbb és rövidebb távon érzékelhető. Az általam vizsgált tőkeallokációs téma igen hálás ilyen szempontból, hiszen miközben matematikailag is nagyon jól vizsgálható probléma, a gyakorlati felhasználása is egyértelmüen adott. Ezzel együtt a tőkeallokációval kapcsolatos kutatások fontos hiányossága, hogy az akadémiai kutatás és az alkalmazás között ma még elég jelentős a távolság. Dolgozatomban megkíséreltem tehát a tőkeallokációs probléma részletes módszertani vizsgálata mellett a gyakorlati alkalmazással kapcsolatos kérdéseket is áttekinteni, s ezáltal egyfajta hidat képezni, amely segít csökkenteni ez előbb említett távolságot.

A bevezető és szükséges fogalmakat tisztázó fejezeteket követően a dolgozat első fő részét az elméleti kutatás eredményeit összegző 2. rész adja. Ebben a koherens kockázatmértékek osztályán hét módszert elemeztünk (egyéni kockázattal arányos; béta; növekményi; költségrés módszer; marginális kockázati hozzájárulás parciális, illetve iránymenti deriváltként értelmezve; továbbá a Shapley- és nukleolusz módszerek) tíz lehetséges tulajdonság szempontjából (mindig értelmezettség, magbeliség, diverzifikáció, erős monotonitás, ösztönzés, hatékonyság, egyenlően kezelés, kockázatmentes allokáció, kovariancia, dekompozíció invariancia). A vizsgálatot részben Csóka és Pintér (2016) tétele indokolja, mely szerint koherens kockázatmérték alkalmazása mellett nincs olyan tőkeallokációs módszer, amely egyszerre lenne mindig értelmezett, magbeli és ösztönző. Az egyes módszerek tulajdonságait összefoglaló táblázatban jelenítettük meg (19. táblázat), amely már önmagában segítséget nyújthat az alkalmazóknak, amikor módszert választanak, 
vagy egy-egy kiválasztott módszer kapcsán potenciálisan felmerülő problémákra szeretnének felkészülni.

Szintén megvizsgáltuk, hogy véletlenszerüen generált tőkeallokációs szituációk esetében milyen arányban eredményez magbeli allokációt az egyéni kockázattal arányos, a béta, a növekményi, a költségrés és a Shapley-módszer legfeljebb 9 alegység esetén, 24 különböző verzióban. Megmutattuk, hogy a vizsgált módszerek közül a költségrés módszer teljesít legjobban, általában 90\% feletti arányban magbeli elosztást eredményezve, bár az arány akár 30\% alá is csökkenhet. Általánosságban elmondható, hogy az, hogy az egyes módszerek milyen arányban adnak magbeli allokációt erősen függ a konkrét tőkeallokációs szituáció paramétereitől, de az alegységek számának növelésével mindig csökken. Szintén hasznos lenne további kutatási kérdésként hasonló vizsgálatot végezni a diverzifikáció, a kockázatmentes allokáció, kovariancia és dekompozíció invariancia tulajdonságok kapcsán, komoly kihívás az ösztönzés, az erős monotonitás és az egyenlően kezelés tulajdonságok esetében; a mindig értelmezettség és a hatékonyság kritériumok esetében viszont nem szükséges.

A pénzügyi idősorok jellemzően zajosak, amit realizációs vektorokat szimulálásával modelleztünk. Kiderült, hogy a realizációs vektorok alkalmazásának előnye (akár historikus szimulációval, akár az elméleti eloszlásból történő mintagenerálással), hogy a marginális hozzájárulás mindkét definíció szerint értelmezett és magbeli elosztást eredményez.

Mivel Csóka és Pintér (2016) megmutatta, hogy egyedül a Shapley-módszer teljesíti a mindig értelmezettség, az egyenlően kezelés, erős monotonitás (így ösztönzés), és a hatékonyság tulajdonságokat, különös figyelmet érdemel, hogy a magbeliség elvárásának viszont nem tesz eleget. Szimulációs vizsgálatunk megmutatta, hogy a Shapley-módszer minden verzióban az esetek szignifikáns részében a magon kívüli elosztást eredményez. Így 
a Csóka és Pintér (2016) által azonosított probléma tehát nem csak elméletben, hanem a gyakorlatban is jelentőséggel bír.

A 3. részben ezután a tőkeallokáció biztosítótársaságoknál történő alkalmazásával kapcsolatos gyakorlati kérdésekre fókuszáltam. Ahogyan az módszertani rész eredményei is megerősítették: a tőkeallokációs problémára nem létezik univerzális, minden helyzetben alkalmazható legjobb megoldás, s felmerül a kérdés, hogy akkor mégis hogyan, milyen szempontok alapján érdemes módszert választani a gyakorlati felhasználás során. E választást elősegítendő, a módszerválasztás során fontos szempontokat gyüjtöttem össze, $\mathrm{s}$ a tőkeallokáció implementálása során felmerülő kérdéseket tekintettem át. Legfontosabb megállapításom e tekintetben, hogy az alkalmazni kívánt módszer minden esetben a felhasználás céljához kell, hogy illeszkedjen.

A biztosítási szektorban az alábbi legfontosabb felhasználási területeket azonosítottam: teljesítményértékelés, stratégiai döntések támogatása, illetve árazás. Az alkalmazható módszereket három csoportba soroltam, s meghatároztam, hogy az egyes felhasználási területekhez mely módszerek felelnek meg leginkább.

Megállapítottam, hogy a teljesítményértékelés során való alkalmazásra, és a stratégiai döntések támogatására is leginkább a kockázatnövekmény alapú módszerek megfelelőek. Ezek a kockázatot az egyes alegységek között az általuk okozott kockázatnövekményt figyelembe véve osztják szét. Az „utolsó belépő” típusú módszerek (Venter, 2009) a teljes portfólión értelmezik a növekményt $\left(\rho\left(X_{N}\right)-\rho\left(X_{N \backslash\{i\}}\right)\right), \mathrm{s}$ ez alapján osztják szét a kockázatot, különböző típusú korrekciókat alkalmazva (vagy nem alkalmazva) a teljes szétosztás, azaz a hatékonyság eléréséhez. E módszerek leginkább tervezett felvásárlások, összeolvadások, új üzletág indításának értékelése, vagy létező üzletág megszüntetéséről való döntés során alkalmasak leginkább, hiszen ilyen esetekben valóban fixnek feltételezhetjük a teljes portfóliót, s a szóban forgó üzletág ehhez való viszonya alapján döntünk. A 
kockázatnövekmény alapú szétosztások közé tartozik még a játékelméletböl jól ismert Shapley-módszer (Shapley, 1953), amely a kockázatot még mindig az adott egység által okozott kockázatnövekmény alapján osztja szét, de már nem csak a teljes biztosító adott egység nélküli portfóliójához $(N \backslash\{i\})$, hanem minden lehetséges $S \subseteq N \backslash\{i\}$ halmazhoz képest értékelve. A módszer számos kedvező tulajdonsággal rendelkezik, és kiválóan alkalmazható a teljesítményértékelés során.

Az egyes felhasználási területek áttekintésénél kitértem arra is, hogy nincs egyetértés arra vonatkozóan, hogy az árazás során szükséges-e tőkeallokációs módszereket alkalmazni (ld. pl. Bingham, 2015a). Ugyanis egyrészröl jogos elvárás a tulajdonosok részéről, hogy az egyes termékek árában jelenjen meg a tőke költsége is, másrészről viszont keresleti oldalról nézve a valóságban az ügyfelek nem (vagy csak nagyon kivételes esetben) fognak többet fizetni egy jobb tőkeellátottságú biztosító által kínált termékért, vagyis a verseny nem teszi lehetővé az allokált tőkeköltség beépítését a termék árába (ugyanakkor a menedzsment számára ez esetben is kétségkívül fontos információt hordoz az egyes üzletágakra, termékekre allokált tőke). Amennyiben azonban a biztosító úgy dönt, hogy használ tőkeallokációt az árazás során, akkor ehhez koncepciójukban leginkább a marginális kockázati hozzájárulás alapú módszerek illeszkednek, mivel ezek alkalmazása esetén az elosztás egy-egy egység hozzájárulásának infitezimálisan kis egységén alapul.

A módszerek harmadik csoportját az arányos szétosztások alkotják (egyéni kockázattal arányos módszer, béta módszer). Ezek a módszerek igen egyszerüen implementálhatóak, ugyanakkor tulajdonságaik kevésbé kedvezőek, ebből következően leginkább külső (jellemzően szabályozói) előírás esetén lehet indokolt az alkalmazásuk.

A módszerek fenti struktúrába rendezése mellett az alkalmazók számára szintén segítséget jelenthet a módszerek kiválasztása során az az összefoglaló táblázat, amelyben azt 
gyüjtöttem össze, hogy az egyes általunk is vizsgált tulajdonságok milyen különböző neveken találhatóak meg az irodalomban.

A tőkeallokáció gyakorlati felhasználásával kapcsolatban két további lehetséges kutatási irányt azonosítottam. Egyrészt, bár kevésbé jellemző, mint a biztosítási szektorban, de a bankszektorban is alkalmaznak tőkeallokációs módszereket, s hasznos lenne a banki specifikumokat is megvizsgálni (elméleti szempontból viszont a két esetben az alapkérdés teljesen azonos). Másrészt, bár ez meglehetősen nehéz feladat az adatok bizalmas volta miatt, de rendkívül hasznos lenne egy-egy biztosító gyakorlatban ténylegesen alkalmazott tőkeallokációs módszertanát feldolgozása esettanulmány formájában. Ahogyan Bingham (2015b, p54) is fogalmaz: „Bár az irodalomban igen szerteágazó a kockázat és hozam viszonyának technikai elemzése, sokkal több figyelmet érdemelnének azon ténylegesen müködö megoldások, melyeket valóban alkalmaznak is."

A dolgozatot az utolsó részben végül egy (a fenti okokból) fiktív esettanulmány zárja, amelynek segítségével a tőkeallokáció egy lehetséges alkalmazását szemléltetem. 


\section{MELLÉKLETEK}

\section{1. melléklet: Vállalati kockázatkezelés (Enterprise Risk Management, ERM) a biztosítási szektorban}

A biztosítók alap üzleti tevékenysége a kockázatvállalásra épül, továbbá a klasszikus biztosítási kockázatok mellett a szektor szereplői számos egyéb kockázattípusnak is ki vannak téve (pl. piaci kockázat, müködési kockázat, hitelkockázat), aminek eredményeképp a legtöbb biztosító meglehetősen szofisztikált kockázatmérési és -kezelési technikákat alkalmaz. Azonban a fejlett kockázatmérési technikák megléte csak egyfajta minimum elvárásnak való megfelelést jelent a szektorban, az egyes biztosítókat egymástól elválasztó kritérium sokkal inkább a teljes vállalati kockázatkezelési, az ún. Enterprise Risk Management (továbbiakban ERM) rendszer fejlettsége. Röviden összefoglalva, az ERM rendszer legfőbb feladata a kockázatkezelési információk integrálása a vállalatirányítási folyamatokba, amely a Szolvencia II bevezetésével mára részben szabályozói elvárássá is várt az ORSA, illetve (belső modellt használó biztosítók esetében) a Use Test keretében. Minél fejlettebb egy biztosító ERM rendszere, a kockázatkezelési funkció annál inkább válik a szabályozói megfelelést biztosító, elszigetelten müködő szervezeti egységből a vállalat értékének növeléséhez nagyban hozzá járuló, az üzleti területekkel és a menedzsmenttel szoros kapcsolatban müködő területté.

Az ERM keretrendszer feladatainak és céljainak pontos megértését nagyban segíti az ERM rendszer különböző fejlettségi szintjeinek megismerése, melyet az alábbiakban Bongiovanni et al. (2016) alapján mutatok be.

A kevésbé fejlett vállalati kockázatkezelési rendszerrel rendelkező vállalatokban a kockázatkezelési feladat leginkább monitoring jellegü: a cél a vállalatot érintő kockázatok 
számszerüsítése, és elsősorban reaktív kezelése. Ezen a szinten a biztosító még nem rendelkezik szofisztikált belső kockázatmérési modellekkel (gazdasági tőkeszámítás), a kockázatkezelési terület feladata elsősorban a szabályzatok elkészítésére, riportok készítésére korlátozódik.

Az ERM következő szintje már proaktív kockázat megközelítést és az üzleti folyamatokba beépülő kockázatkezelési gyakorlatot feltételez. A kockázatkezelésnek itt már fontos szerepe van a vállalat értékének megőrzésében. A kockázatkezelési szakemberek folyamatos kapcsolatot tartanak az üzleti területekkel, véleményezik az üzleti döntéseket. Proaktívan azonosítják és jelzik az esetleges problémákat.

A legfejlettebb ERM rendszerrel rendelkező biztosítóknál a kockázatkezelés már fontos és elengedhetetlen tényezője a vállalati értékteremtésnek. Ekkor már nem csak a napi szintü üzleti döntésekben, de a biztosító stratégiájának kialakításában is részt vesz a kockázati terület, amely a szervezet teljesen integrált része. A vezetőség a kockázat-hozam összefüggések átlátása mellett hozza döntéseit. 


\section{2. melléklet: Szimulációs eredmények a magbeliség ellenőrzésére, négy további verzió}

Az alábbiakban 4 szimulációs verziót mutatunk be 3-9 alegység mellett. A kis szórás és a maximális veszteség kockázatmérték alkalmazásának hatásai a 28 . táblázat-30. táblázatokban találhatóak. A 31. táblázatban Homburg és Scherpereel (2008) eredményeit reprodukáljuk.

28. táblázat: M-arányok és standard hibák azonos portfólió méret, kis szórás, normális eloszlás és 95\%-Expected Shortfall mellett

\begin{tabular}{|c|c|c|c|c|c|}
\hline & \multicolumn{5}{|c|}{ Tőkeallokációs módszer } \\
\hline $\mathrm{N}$ & $\begin{array}{l}\text { Egyéni kock. } \\
\text { arányos }\end{array}$ & Béta & Növekményi & Költségrés & Shapley \\
\hline \multirow{2}{*}{3} & $62,65 \%$ & $83,07 \%$ & $36,77 \%$ & $100,00 \%$ & $92,06 \%$ \\
\hline & $(0,49 \%)$ & $(0,36 \%)$ & $(0,48 \%)$ & $(0,00 \%)$ & $(0,26 \%)$ \\
\hline \multirow{2}{*}{4} & $39,34 \%$ & $75,23 \%$ & $18,71 \%$ & $99,95 \%$ & $85,07 \%$ \\
\hline & $(0,50 \%)$ & $(0,44 \%)$ & $(0,39 \%)$ & $(0,02 \%)$ & $(0,35 \%)$ \\
\hline \multirow{2}{*}{5} & $25,34 \%$ & $67,14 \%$ & $10,60 \%$ & $98,83 \%$ & $76,59 \%$ \\
\hline & $(0,44 \%)$ & $(0,47 \%)$ & $(0,32 \%)$ & $(0,11 \%)$ & $(0,43 \%)$ \\
\hline \multirow{2}{*}{6} & $15,20 \%$ & $59,83 \%$ & $5,83 \%$ & $98,00 \%$ & $69,21 \%$ \\
\hline & $(0,35 \%)$ & $(0,51 \%)$ & $(0,23 \%)$ & $(0,14 \%)$ & $(0,45 \%)$ \\
\hline \multirow{2}{*}{7} & $9,74 \%$ & $52,51 \%$ & $3,43 \%$ & $96,78 \%$ & $63,26 \%$ \\
\hline & $(0,31 \%)$ & $(0,50 \%)$ & $(0,18 \%)$ & $(0,17 \%)$ & $(0,50 \%)$ \\
\hline \multirow{2}{*}{8} & $6,35 \%$ & $45,88 \%$ & $1,75 \%$ & $95,83 \%$ & $56,33 \%$ \\
\hline & $(0,25 \%)$ & $(0,51 \%)$ & $(0,13 \%)$ & $(0,21 \%)$ & $(0,49 \%)$ \\
\hline \multirow{2}{*}{9} & $3,76 \%$ & $40,38 \%$ & $0,89 \%$ & $95,70 \%$ & $49,91 \%$ \\
\hline & $(0,18 \%)$ & $(0,50 \%)$ & $(0,09 \%)$ & $(0,20 \%)$ & $(0,50 \%)$ \\
\hline
\end{tabular}


29. táblázat: M-arányok és standard hibák azonos portfólió méret, kis szórás, t-eloszlás és maximális veszteség mellett

\begin{tabular}{|c|c|c|c|c|c|}
\hline & \multicolumn{5}{|c|}{ Tőkeallokációs módszer } \\
\hline $\mathrm{N}$ & $\begin{array}{l}\text { Egyéni kock. } \\
\text { arányos }\end{array}$ & Béta & Növekményi & Költségrés & Shapley \\
\hline \multirow{2}{*}{3} & $56,33 \%$ & $45,33 \%$ & $30,97 \%$ & $100,00 \%$ & $74,96 \%$ \\
\hline & $(0,49 \%)$ & $(0,48 \%)$ & $(0,44 \%)$ & $(0,00 \%)$ & $(0,43 \%)$ \\
\hline \multirow{2}{*}{4} & $36,53 \%$ & $28,24 \%$ & $17,82 \%$ & $99,17 \%$ & $58,63 \%$ \\
\hline & $(0,47 \%)$ & $(0,45 \%)$ & $(0,39 \%)$ & $(0,09 \%)$ & $(0,49 \%)$ \\
\hline \multirow{2}{*}{5} & $23,94 \%$ & $17,92 \%$ & $12,07 \%$ & $90,85 \%$ & $45,54 \%$ \\
\hline & $(0,43 \%)$ & $(0,39 \%)$ & $(0,33 \%)$ & $(0,29 \%)$ & $(0,51 \%)$ \\
\hline \multirow{2}{*}{6} & $15,33 \%$ & $11,08 \%$ & $10,03 \%$ & $78,97 \%$ & $33,56 \%$ \\
\hline & $(0,37 \%)$ & $(0,32 \%)$ & $(0,29 \%)$ & $(0,40 \%)$ & $(0,49 \%)$ \\
\hline \multirow{2}{*}{7} & $10,11 \%$ & $7,37 \%$ & $9,79 \%$ & $65,91 \%$ & $24,82 \%$ \\
\hline & $(0,30 \%)$ & $(0,26 \%)$ & $(0,29 \%)$ & $(0,47 \%)$ & $(0,43 \%)$ \\
\hline \multirow{2}{*}{8} & $6,29 \%$ & $4,33 \%$ & $9,95 \%$ & $52,79 \%$ & $17,50 \%$ \\
\hline & $(0,25 \%)$ & $(0,20 \%)$ & $(0,30 \%)$ & $(0,51 \%)$ & $(0,39 \%)$ \\
\hline \multirow{2}{*}{9} & $4,12 \%$ & $2,56 \%$ & $9,29 \%$ & $41,65 \%$ & $11,69 \%$ \\
\hline & $(0,20 \%)$ & $(0,16 \%)$ & $(0,29 \%)$ & $(0,50 \%)$ & $(3,20 \%)$ \\
\hline
\end{tabular}


30. táblázat: M-arányok és standard hibák különbözö portfólió méret, kis szórás, t-eloszlás és maximális veszteség mellett

\begin{tabular}{|c|c|c|c|c|c|}
\hline & \multicolumn{5}{|c|}{ Tőkeallokációs módszer } \\
\hline $\mathrm{N}$ & $\begin{array}{l}\text { Egyéni kock. } \\
\text { arányos }\end{array}$ & Béta & Növekményi & Költségrés & Shapley \\
\hline \multirow{2}{*}{3} & $50,34 \%$ & $28,36 \%$ & $26,44 \%$ & $100,00 \%$ & $82,10 \%$ \\
\hline & $(0,50 \%)$ & $(0,46 \%)$ & $(0,44 \%)$ & $(0,00 \%)$ & $(0,38 \%)$ \\
\hline \multirow{2}{*}{4} & $31,12 \%$ & $16,91 \%$ & $15,57 \%$ & $99,79 \%$ & $72,06 \%$ \\
\hline & $(0,46 \%)$ & $(0,38 \%)$ & $(0,37 \%)$ & $(0,05 \%)$ & $(0,46 \%)$ \\
\hline \multirow{2}{*}{5} & $22,59 \%$ & $9,48 \%$ & $10,97 \%$ & $97,09 \%$ & $61,32 \%$ \\
\hline & $(0,43 \%)$ & $(0,29 \%)$ & $(0,31 \%)$ & $(0,16 \%)$ & $(0,50 \%)$ \\
\hline \multirow{2}{*}{6} & $16,58 \%$ & $5,89 \%$ & $8,14 \%$ & $91,93 \%$ & $52,88 \%$ \\
\hline & $(0,37 \%)$ & $(0,24 \%)$ & $(0,28 \%)$ & $(0,27 \%)$ & $(0,49 \%)$ \\
\hline \multirow{2}{*}{7} & $13,07 \%$ & $3,26 \%$ & $7,08 \%$ & $85,32 \%$ & $43,21 \%$ \\
\hline & $(0,33 \%)$ & $(0,18 \%)$ & $(0,26 \%)$ & $(0,36 \%)$ & $(0,49 \%)$ \\
\hline \multirow{2}{*}{8} & $9,69 \%$ & $1,82 \%$ & $6,90 \%$ & $78,80 \%$ & $35,53 \%$ \\
\hline & $(0,30 \%)$ & $(0,13 \%)$ & $(0,24 \%)$ & $(0,42 \%)$ & $(0,48 \%)$ \\
\hline \multirow{2}{*}{9} & $7,75 \%$ & $1,35 \%$ & $6,14 \%$ & $70,67 \%$ & $28,60 \%$ \\
\hline & $(0,27 \%)$ & $(0,11 \%)$ & $(0,24 \%)$ & $(0,45 \%)$ & $(0,46 \%)$ \\
\hline
\end{tabular}


31. táblázat: M-arányok és standard hibák azonos portfólió méret, nagy szórás, normális eloszlás és 84,14\% VaR mellett

\begin{tabular}{|c|c|c|c|c|c|}
\hline & \multicolumn{5}{|c|}{ Tőkeallokációs módszer } \\
\hline $\mathrm{N}$ & $\begin{array}{l}\text { Egyéni kock. } \\
\text { arányos }\end{array}$ & Béta & Növekményi & Költségrés & Shapley \\
\hline \multirow{2}{*}{3} & $69,20 \%$ & $100,00 \%$ & $40,61 \%$ & $100,00 \%$ & $97,01 \%$ \\
\hline & $(0,45 \%)$ & $(0,00 \%)$ & $(0,48 \%)$ & $(0,00 \%)$ & $(0,17 \%)$ \\
\hline \multirow{2}{*}{4} & $52,91 \%$ & $100,00 \%$ & $25,67 \%$ & $100,00 \%$ & $94,41 \%$ \\
\hline & $(0,51 \%)$ & $(0,00 \%)$ & $(0,43 \%)$ & $(0,00 \%)$ & $(0,23 \%)$ \\
\hline \multirow{2}{*}{5} & $41,84 \%$ & $100,00 \%$ & $17,92 \%$ & $99,59 \%$ & $91,89 \%$ \\
\hline & $(0,50 \%)$ & $(0,00 \%)$ & $(0,38 \%)$ & $(0,06 \%)$ & $(0,20 \%)$ \\
\hline \multirow{2}{*}{6} & $33,95 \%$ & $100,00 \%$ & $12,41 \%$ & $99,11 \%$ & $88,33 \%$ \\
\hline & $(0,47 \%)$ & $(0,00 \%)$ & $(0,33 \%)$ & $(0,09 \%)$ & $(0,33 \%)$ \\
\hline \multirow{2}{*}{7} & $27,63 \%$ & $100,00 \%$ & $8,75 \%$ & $98,99 \%$ & $85,60 \%$ \\
\hline & $(0,42 \%)$ & $(0,00 \%)$ & $(0,27 \%)$ & $(0,10 \%)$ & $(0,34 \%)$ \\
\hline \multirow{2}{*}{8} & $22,35 \%$ & $100,00 \%$ & $6,02 \%$ & $98,80 \%$ & $81,58 \%$ \\
\hline & $(0,40 \%)$ & $(0,00 \%)$ & $(0,24 \%)$ & $(0,11 \%)$ & $(0,39 \%)$ \\
\hline \multirow{2}{*}{9} & $18,26 \%$ & $100,00 \%$ & $4,03 \%$ & $98,75 \%$ & $78,42 \%$ \\
\hline & $(0,38 \%)$ & $(0,00 \%)$ & $(0,19 \%)$ & $(0,10 \%)$ & $(0,40 \%)$ \\
\hline
\end{tabular}




\section{3. melléklet: A leggyakrabban előforduló tulajdonságok különböző elnevezései a szakirodalomban}

\begin{tabular}{|c|c|c|c|c|c|c|c|c|c|}
\hline $\begin{array}{l}\text { Tulajdonság / } \\
\text { Szerző }\end{array}$ & $\begin{array}{l}\text { Balog et al. } \\
\mathbf{( 2 0 1 7 )} \text { - jelen } \\
\text { tanulmány } 2 . \\
\text { fejezete }\end{array}$ & $\begin{array}{l}\text { Denault (2001), } \\
\text { Buch \& } \\
\text { Dorfleitner } \\
\text { (2008); De } \\
\text { Angelis \& } \\
\text { Granito (2015) }\end{array}$ & $\begin{array}{l}\text { Kalkbrener } \\
(2005)\end{array}$ & $\begin{array}{l}\text { Tasche } \\
(2008)\end{array}$ & $\begin{array}{l}\text { Homburg és } \\
\text { Scherpereel } \\
(2008)\end{array}$ & $\begin{array}{l}\text { Tsanakas et } \\
\text { al. }(2010)\end{array}$ & $\begin{array}{l}\text { Csóka és } \\
\text { Pintér (2016) }\end{array}$ & $\begin{array}{l}\text { Maume- } \\
\text { Deschamps } \\
\text { et al. }(\mathbf{2 0 1 6})\end{array}$ & $\begin{array}{l}\text { Balog et al. } \\
\text { (2011) }\end{array}$ \\
\hline 1) Hatékony & Efficiency & & & $\begin{array}{l}\text { Full } \\
\text { allocation }\end{array}$ & & $\begin{array}{l}\text { Full } \\
\text { allocation }\end{array}$ & Efficiency & $\begin{array}{l}\text { Full } \\
\text { allocation }\end{array}$ & \\
\hline $\begin{array}{l}\text { 2) Mindenhol } \\
\text { értelmezett }\end{array}$ & Full domain & & & & & & & & \\
\hline 3) Diverzifikáló & Diversification & & $\begin{array}{l}\text { Diversifi- } \\
\text { cation }\end{array}$ & & $\begin{array}{l}\text { Individual } \\
\text { core condition }\end{array}$ & & & & \\
\hline 4) Magallokáció & $\begin{array}{l}\text { Core compa- } \\
\text { tibility }\end{array}$ & No undercut & & & $\begin{array}{l}\text { Core compa- } \\
\text { tibility }\end{array}$ & & $\begin{array}{l}\text { Core comp. / } \\
\text { Coalitionally } \\
\text { rational }\end{array}$ & & Stabil \\
\hline $\begin{array}{l}\text { 5) Egyenlően } \\
\text { kezelő }\end{array}$ & $\begin{array}{l}\text { Equal } \\
\text { treatment prop. }\end{array}$ & Symmetry & & & & & $\begin{array}{l}\text { Equal } \\
\text { treatment prop. }\end{array}$ & Symmetry & $\begin{array}{l}\text { Szimmet- } \\
\text { rikus }\end{array}$ \\
\hline $\begin{array}{l}\text { 6) Kockázatmen- } \\
\text { tes allokáció }\end{array}$ & $\begin{array}{l}\text { Riskless } \\
\text { portfolio }\end{array}$ & $\begin{array}{l}\text { Riskless } \\
\text { allocation }^{40}\end{array}$ & & & & & & $\begin{array}{l}\text { Riskless } \\
\text { allocation }\end{array}$ & \\
\hline $\begin{array}{l}\text { 7) Erős } \\
\text { monotonitás }\end{array}$ & $\begin{array}{l}\text { Strong } \\
\text { monotonicity }\end{array}$ & & & & & & $\begin{array}{l}\text { Strong } \\
\text { monotonicity }\end{array}$ & & Ösztönzö \\
\hline 8) Ösztönző & $\begin{array}{l}\text { Incentive } \\
\text { compatibility }\end{array}$ & & & & & & $\begin{array}{l}\text { Incentive } \\
\text { compatibility }\end{array}$ & & \\
\hline $\begin{array}{l}\text { 9) Dekompozíció } \\
\text { invariancia }\end{array}$ & $\begin{array}{l}\text { Decomposition } \\
\text { invariance }\end{array}$ & & $\begin{array}{l}\text { Alapértelme- } \\
\text { zett elvárás }{ }^{41}\end{array}$ & & & & & & \\
\hline
\end{tabular}

${ }^{40}$ Deanult (2001) a kockázatmentes allokáció tulajdonságra „dummy player property” néven is hivatkozik.

${ }^{41}$ Külön néven nem szerepel 


\section{FelHaSznált irodalom}

Acerbi C, Scandolo G [2008]: Liquidity Risk Theory and Coherent Measures of Risk.

Quantitative Finance 8: 681-692, DOI: $\underline{\text { http://dx.doi.org/10.1080/14697680802373975 }}$

Acerbi C, Székely B [2017]: General Properties of Backtestable Statistics. Working Paper, DOI: http://dx.doi.org/10.2139/ssrn.2905109

Acerbi C, Tasche D [2002]: On the Coherence of Expected Shortfall. Journal of Banking and Finance 26: 1487-1504, DOI: http://dx.doi.org/10.1016/S0378-4266(02)00283-2

Albrecht P [2006]: Risk based capital allocation. In: Encyclopedia of Actuarial Science. Wiley, Chichester

Artzner PF, Delbaen F, Eber JM, Heath D [1999]: Coherent Measures of Risk. Mathematical Finance 9: 203-228, DOI: 10.1111/1467-9965.00068

Assa H, Morales M, Firouzi HO [2016]: On the Capital Allocation Problem for a New Coherent Risk Measure in Collective Risk Theory. Risks 4 (3): 30, DOI: 10.3390/risks4030030

Aumann RJ, Shapley LS [1974]: Values of Non-atomic Games. Princeton University Press, $w$ ww.jstor.org/stable/j.ctt13x149m

Balog D, Csóka P, Pintér MP, Bátyi TL [2011]: Tőkeallokációs módszerek és tulajdonságaik a gyakorlatban. Közgazdasági Szemle 7-8: 619-632

Balog D, Csóka P, Pintér MP, Bátyi TL [2017]: Properties and comparison of risk capital allocation methods. European Journal of Operational Research 259 (2): 614-625, DOI: http://dx.doi.org/10.1016/j.ejor.2016.10.052

Balogh Cs [2006]: Felmérés a banki belső tőkeallokáció hazai alkalmazásáról. Hitelintézeti Szemle 5 (4): $32-54$ 
BCoBS [2014]: Consultative Document. Fundamental Review of the Trading Book: Outstanding Issues. Tech. rep., Basel Committee on Banking Supervision. Basel: Bank for International Settlements

Bingham R [2014]: Using the Risk Coverage Ratio to Integrate Risk And Return. Contingencies 26 (6): 54-59, http://www.contingenciesonline.com/contingenciesonline/20141112?pg=57\#pg57

Bingham R [2015a]: Lessons Learned by an Insurance Financial Modeler. Contingencies 27 (1): 54-56, http://www.contingenciesonline.com/contingenciesonline/20150102?pg=56\#pg56

Bingham R [2015b]: Underwriting and Investment Alignment for CRM. Contingencies 27 (2): 49-53, http://www.contingenciesonline.com/contingenciesonline/20150304?pg=50\#pg50

Bolton P, Santos T, Scheinkman JA [2016]: Savings Gluts and Financial Fragility. Working Paper, DOI: http://dx.doi.org/10.2139/ssrn.2743700

Bondareva ON [1963]: Some applications of linear programming methods to the theory of cooperative games. Problemy Kybernetiki 10, 119-139

Bongiovanni C, Pancaldi L, Stegernann U, Taglioni G [2016]: Transforming enterprise risk management for value in the insurance industry. McKinsey \& Company Report. http://www.mckinsey.com/business-functions/risk/our-insights/transformingenterprise-risk-management-for-value-in-the-insurance-industry

Boonen T, De Waegenaere A, Norde H [2012]: A Generalization of the Aumann-Shapley Value for Risk Capital Allocation Problems. CentER Discussion Paper Series No. 2012-091, DOI: http://dx.doi.org/10.2139/ssrn.2181938

Borio C, Disyatat P [2011]: Global imbalances and the financial crisis: Link or no link? BIS Working Papers, no. 346, https://www.bis.org/publ/work346.pdf

Buch A, Doreitner G [2008]: Coherent Risk Measures, Coherent Capital Allocation and the Gradient Allocation Principle. Insurance: Mathematics and Economics 42 (1): 235242, DOI: $\underline{\text { ttp: } / / d x . \text { doi.org/10.1016/j.insmatheco.2007.02.006 }}$ 
Buch A, Dorfleitner G, Wimmer M (2011) Risk capital allocation for RORAC optimization. Journal of Banking and Finance 35: 3001-3009, DOI: http://dx.doi.org/10.1016/j.jbankfin.2011.04.001

Butsic RP (1994) Solvency Measurement for Property-Liability Risk-Based Capital Applications. Journal of Risk and Insurance, 61: 656-690, DOI: 10.2307/253643

Cherny A, Orlov D [2011]: On Two Approaches to Coherent Risk Contribution. Mathematical Finance 21 (3-4): 557-571, DOI: 10.1111/j.1467-9965.2010.00441.x

Cont R [2001]: Empirical Properties of Asset Returns: Stylized Facts and Statistical Issues. Quantitative Finance 1: 223-236, DOI: http://dx.doi.org/10.1080/713665670

Csóka P [2003]: Koherens kockázatmérés és tőkeallokáció. Közgazdasági Szemle 50 (10): $855-880$

Csóka P, Herings PJJ, Kóczy LÁ [2007]: Coherent Measures of Risk from a General Equilibrium Perspective. Journal of Banking and Finance 31 (8): 2517-2534, DOI: http://dx.doi.org/10.1016/j.jbankfin.2006.10.026

Csóka P, Herings PJJ, Kóczy LÁ [2009]: Stable Allocations of Risk. Games and Economic Behavior 67 (1): 266-276, DOI: http://dx.doi.org/10.1016/j.geb.2008.11.001

Csóka P, Herings PJJ [2014]: Risk Allocation under Liquidity Constraints. Journal of Banking and Finance 49: 1-9, DOI: http://dx.doi.org/10.1016/j.jbankfin.2014.08.017

Csóka P, Pintér M [2016]: On the Impossibility of Fair Risk Allocation. The B.E. Journal of Theoretical Economics 16 (1): 143-158, DOI: https://doi.org/10.1515/bejte-2014$\underline{0051}$

Cummins JD, Freifelder LR [1978]: A Comparative Analysis of Alternative Probable Yearly Aggregate Loss Estimators. The Journal of Risk and Insurance 45 (1): 27-52, DOI: $10.2307 / 251806$

Cummins JD [2000]: Allocation of Capital in the Insurance Industry. Risk Management and Insurance Review 3: 7-28, DOI: 10.1111/j.1540-6296.2000.tb00013.x 
Davis M, Etheridge A. [2006]: Louis Bachelier's Theory of Speculation: The Origins of Modern Finance. Princeton University Press. http://www.jstor.org/stable/j.ctt7scn4.9

De Angelis P, Granito I [2015]: Capital allocation and risk appetite under Solvency II framework. Mühelytanulmány. https://arxiv.org/abs/1511.02934

Denault M [2001]: Coherent Allocation of Risk Capital. Journal of Risk 4 (1): 1-34, DOI: 10.21314/JOR.2001.053

Dhaene J, Tsanakas A, Valdez EA, Vanduffel A [2012]. Optimal Capital Allocation Principles. Journal of Risk and Insurance 79 (1): 1-28, DOI: 10.1111/j.15396975.2011.01408.x

Dionne G [2013]: Risk Management: History, Definition and Critique. Working Paper. http://www.cirpee.org/fileadmin/documents/Cahiers_2013/CIRPEE13-02.pdf

European Commission [2009]: Directive 2009/138/EC of the European parliament and of the council of 25 November 2009 on the taking-up and pursuit of the business of insurance and reinsurance (Solvency II). Official Journal of the European Union, p. L335.

Farr I, Mueller H, Scanlon M, Stronkhorst S [2008]: Economic Capital for Life Insurance Companies. Society of Actuaries Report. https://www.soa.org/files/pdf/research-ecreport.pdf

Girsanov IV [1972]: Lectures on Mathematical Theory of Extremum Problems, Lecture Notes in Economics and Mathematical Systems, vol 67. Springer-Verlag

Goldfarb R [2010]: Risk-Adjusted Performance Measurement for P\&C Insurers. Working Paper. http://www.casact.org/library/studynotes/goldfarb8.2.pdf

Gordon JN [2002]: What Enron Means for the Management and Control of the Modern Business Corporation: Some Initial Reflections. The University of Chichago Law Review 69 (3): 1233-1250, DOI: 10.2307/1600646

Grechuk B [2015]: The Center of a Convex Set and Capital Allocation. European Journal of Operational Research 243:628-636, DOI: 10.1016/j.ejor.2014.12.004 
Greener I [2006]: Nick Leeson and the Collapse of Barings Bank: Socio-Technical Networks and the 'Rogue Trader'. Organization 13 (3): 421-441, DOI:

$10.1177 / 1350508406063491$

Hamlen SS, Hamlen WA, Tschirhart JT [1977]: The Use of Core Theory in Evaluating Joint Cost Allocation Games. The Accounting Review 52:616-627

Homburg C, Scherpereel P [2008]: How Should the Cost of Joint Risk Capital be Allocated for Performance Measurement? European Journal of Operational Research 187 (1): 208-217, DOI: http://dx.doi.org/10.1016/j.ejor.2007.03.020

Hougaard JL, Smilgins A [2016]: Risk Capital Allocation with Autonomous Subunits: The Lorenz Set, Insurance: Mathematics and Economics 67: 151-157, DOI: http://dx.doi.org/10.1016/j.insmatheco.2015.12.002

Ingram D [2004]: Getting to Know CTE. Risk Management Newsletter 2: 33-38, https://www.soa.org/library/newsletters/risk-management-newsletter/2004/july/rm2004-iss02-ingram-b.aspx

Jorion P [2007]: Value at Risk: The New Benchmark for Managing Financial Risk. McGraw - Hill

Kalkbrener M [2005]: An Axiomatic Approach to Capital Allocation. Mathematical Finance 15[3]:425-437, DOI: 10.1111/j.1467-9965.2005.00227.x

Kaye P [2005]: Risk Measurement in Insurance: A Guide To Risk Measurement, Capital Allocation and Related Decision Support Issues. Casualty Actuary Society Discussion Paper Program. DOI: http://citeseerx.ist.psu.edu/viewdoc/summary?doi=10.1.1.126.321

Kim JHT, Hardy MR [2007]: A Capital Allocation Based on a Solvency Exchange Option. Working Paper.

http://citeseerx.ist.psu.edu/viewdoc/download?doi=10.1.1.412.2088\&rep=rep $1 \&$ type $=p d f$ 
Kondor I, Pafka Sz, Nagy G [2007]: Noise Sensitivity of Portfolio Selection under Various Risk Measures. Journal of Banking and Finance, 31[5]:1545-1573, DOI: http://dx.doi.org/10.1016/j.jbankfin.2006.12.003

Lewandowski D, Kurowicka D, Joe H [2009]: Generating Random Correlation Matrices based on Vines and Extended Onion Method. Journal of Multivariate Analysis 100:1989-2001, DOI: http://dx.doi.org/10.1016/j.jmva.2009.04.008

Mandelbrot B [1963]: The Variation of Certain Speculative Prices. The Journal of Business 36[4]:394-419, DOI: http://dx.doi.org/10.1086/294632

Maume-Deschamps V, Rulliere D, Said K [2016]: On a capital allocation by minimization of some risk indicators. European Actuarial Journal 6 (1): 177-196, DOI: $10.1007 / \mathrm{s} 13385-016-0123-1$

McKinsey\&Company (2014) From Compliance to Value Creation: The Journey to Effective Enterprise Risk Management for Insurers. McKinsey Report. http://www.mckinsey.com/ /media/mckinsey/business\%20functions/risk/our\%20insigh ts/transforming\%20enterprise \%20risk\%20management $\% 20$ for\%20value $\% 20 \mathrm{in} \% 20$ th e\%20insurance\%20industry/from-compliance-to-value-creation.ashx

Merton RC, Perold AF [1993]: Theory of Risk Capital in Financial Firms. Journal of Applied Corporate Finance 6: 16-32, DOI: 10.1111/j.1745-6622.1993.tb00231.x Meyers G [2005]: Allocating Capital: Another Tactic. A Review of Michael Kalkbrener's "An Axiomatic Approach to Capital Allocation". The Actuarial Review 32(4): 25-26

Mueller H [2004]: Specialty Guide on Economic Capital. Society of Actuaries Report. https://www.actuaries.org.uk/documents/specialty-guide-economic-capital

Myers SC, Read JA [2001]: Capital Allocation for Insurance Companies. Journal of Risk and Insurance 68: 545-580, DOI: 10.2307/2691539

Nocera J [2009]: Risk Management. The New York Times, 2009. http://www.nytimes.com/2009/01/04/magazine/04risk-t.html?pagewanted=1\&_r=1

Peleg B, Sudhölter P [2007]: Introduction to the Theory of Cooperative Games. Vol. 34. Springer Science \& Business Media. 
Peters H [2008]: Game Theory: A Multi-Leveled Approach. Springer-Verlag, Berlin Heidelberg, 2008. DOI: 10.1007/978-3-662-46950-7

Ruhm D, Mango DF [2003]: A Risk Charge Calculation Based on Conditional Probability. 2003 Bowles Symposium, Georgia State University. https://www.casact.com/education/specsem/sp2003/papers/ruhm-mango.doc

Ruhm D, Wolf R [2015]: RCM-3 and 4: Allocating Capital - A Hands-on Case Study. Előadás a Casualty Actuary Society szeminuárumán, 2015. március 11. https://cas.confex.com/cas/rpms15/webprogram/Handout/Paper4123/Wolf_\%20RPM 2015\%20Seminar\%20Session\%20_wolf_ruhm.pdf

Sandström A [2011]: Handbook of Solvency for Actuaries and Risk Managers: Theory and Practice. CRC Finance series. Chapman \& Hall/CRC, 2011.

Schmeidler D [1969]: The Nucleolus of a Characteristic Function Game. SIAM Journal on Applied Mathematics 17:1163-1170, DOI: http://dx.doi.org/10.1137/0120009

Shapley LS [1953]: A value for n-person games. In: Kuhn HW, Tucker AW [eds]:

Contributions to the Theory of Games II, Annals of Mathematics Studies, vol 28, Princeton University Press, Princeton, pp 307-317

Shapley LS [1967]: On balanced sets and cores. Naval Research Logistics 14: 453-460, DOI: 10.1002/nav.3800140404

Sharpe WF [1966]: Mutual Fund Performance. The Journal of Business 39[1]: 119-138, DOI: http://dx.doi.org/10.1086/294846

Sherris M [2006]: Solvency, Capital Allocation, and Fair Rate of Return in Insurance. The Journal of Risk and Insurance 73 (1): 71-96, DOI: 10.1111/j.1365-2966.2006.00166.x

Shin HS [2012]: Global Banking Glut and Loan Risk Premium. IMF Economic Review 60: $155-192$

Solymosi T [2007]: Kooperatív játékelmélet. Elektronikus jegyzet.

Tasche D [2002]: Expected Shortfall and Beyond. Journal of Banking and Finance 26[7]: 1519-1533, DOI: http://dx.doi.org/10.1016/S0378-4266(02)00272-8 
Tasche, D. (2008). Capital Allocation to Business Units and Sub-Portfolios: the Euler Principle. Mühelytanulmány. http://EconPapers.repec.org/RePEc:arx:papers:0708.2542

Tijs SH [1981]: Bounds for the Core of a Game and the $\tau$-Value. Game Theory and Mathematical Economics [Eds. O. Moeschlin, D. Pallaschke]. North Holland Publ. Comp., Amsterdam, 123-132

Tijs SH, Driessen TSH [1986]: Game Theory and Cost Allocation Problems. Management Science 32[8]:1015-1028, DOI: $\underline{10.1287 / m n s c .32 .8 .1015}$

Valdez EA, Chernih A [2003]: Wang's Capital Allocation Formula for Elliptically Contoured Distributions. Insurance: Mathematics and Economics 33:517-532, DOI: http://dx.doi.org/10.1016/j.insmatheco.2003.07.003

van Gulick G, De Waegenaere A, Norde H [2012]: Excess Based Allocation of Risk Capital. Insurance: Mathematics and Economics 50:26-42, DOI: http://dx.doi.org/10.1016/j.insmatheco.2011.09.003

Venter GG [2004]: Capital Allocation Survey with Commentary. North American Actuarial Journal 8 (2): 96-107, DOI: http://dx.doi.org/10.1080/10920277.2004.10596139

Venter GG [2009]: Next Steps for ERM: Valuation and Risk Pricing. Society of Actuaries Report.In Additional Research Papers Submitted to the 2009 ERM Call for Papers, 2009, https://www.soa.org/library/monographs/other-monographs/2009/april/mono2009-m-as09-venter.pdf

Vrieze KJ, Brehm PJ (2003) Review of „Capital Allocation for Insurance Companies” by Steward C. Myers and James R. Read Jr. Practical Considerations for the Implementing the Myers-Read Model. The Casualty Actuarial Society Forum. Fall 2003 Edition: 479-492. http://www.casact.org/pubs/forum/03fforum/03fforum.pdf

Young HP [1985]: Monotonic Solutions of Cooperative Games. International Journal of Game Theory 14:65-72, DOI: 10.1007/BF01769885 
Zec N [2014]: Use of an internal model in a general insurance company: focus on economic capital allocation. Disszertáció. DOI:

http://dx.doi.org/10.2139/ssrn.2161308 


\section{PublikÁCIÓS JEgYZÉK}

\section{Publikációk referált folyóiratban}

Balog Dóra [2017]: Tőkeallokáció a biztosítási szektorban. Hitelintézeti szemle 16 (3): 74 97

Balog Dóra, Csóka Péter, Pintér Miklós Péter, Bátyi Tamás László [2017]: Properties and comparison of risk capital allocation methods. European Journal of Operational Research 259 (2): 614-625, DOI: http://dx.doi.org/10.1016/j.ejor.2016.10.052

Balog Dóra, Csóka Péter, Pintér Miklós Péter, Bátyi Tamás László [2011]: Tőkeallokációs módszerek és tulajdonságaik a gyakorlatban. Közgazdasági Szemle 7-8: 619-632

Balog Dóra, Csóka Péter, Pintér Miklós Péter [2010]: Tőkeallokáció nem likvid portfóliók esetén. Hitelintézeti Szemle 6: 604-616

\section{Egyéb publikációk}

Balog Dóra, Csóka Péter, Pintér Miklós Péter, Bátyi Tamás László [2014]: Properties of risk capital allocation methods: Core Compatibility, Equal Treatment Property and Strong Monotonicity. Mühelytanulmány. $\quad$ http://unipub.lib.unicorvinus.hu/1659/1/cewp_201413.pdf

Balog Dóra, Csóka Péter, Pintér Miklós Péter, Bátyi Tamás László [2012]: Pénzügyi hálózatok modellezése Jackson és Watts (2002) nyomán. Egyensúly és optimum, Aula kiadó, Budapest, 151-168

Balog Dóra [2011]: Capital allocation in financial institutions: the Euler method. KTI Mühelytanulmány. http://econ.core.hu/file/download/mtdp/MTDP1126.pdf 


\section{Konferencia kiadványok}

Balog Dóra [2010]: Risk based capital allocation. Fikusz Symposium for Young Researchers: 17-26

\section{Konferencia előadások}

Balog Dóra [2016]: Tőkeallokáció a biztosítási szektorban. Közgazdaságtani Doktori Iskola Éves Konferenciája. Budapest, 2016. november 24.

Balog Dóra [2012]: Tőkeallokációs módszerek tulajdonságai. Budapesti Operációkutatási Nap. Budapest, 2012. január 27.

Balog Dóra [2011]: Risk based capital allocation. Sing7 Conference. Párizs, 2011. július 18.

Balog Dóra [2010]: Risk based capital allocation. Fikusz Symposium for Young Researchers, Budapest, 2010. november 12. 